WSRC-TR-92-559

\title{
FOUR MILE CREEK SEMI-ANNUAL SAMPLING REPORT JULY 1992 SAMPLING EVENT (U)
}

by WSRC Contact - K. L. Dixon

Westinghouse Savannah River Company

Savannah River Site

Aiken, South Carolina 29808

Other Authors:

Metcalf \& Eddy

Molcalf \& Eddy
WSRC-TR--92-559

DE93 006326 
Westinghouse Savannah River Company

Aiken, South Carolina

\section{Four Mile Creek Semi-Annual Sampling Report July 1992 Sampling Event}

Contract No. AA46327P

Task No. 26

October 1992 
Submitted to:

Westinghouse Savannah River Company

Aiken, South Carolina

\section{Four Mile Creek \\ Semi-Annual Sampling Report July 1992 Sampling Event}

Contract No. AA46327P

Task No. 26

October 1992 
Four Mile Creek

Semi-Annual Sampling Report

July 1992 Sampling Event

Submitted October 14, 1992

\section{TABLE OF CONTENTS}

$1.0 \quad$ INTRODUCTION $\ldots \ldots \ldots \ldots \ldots \ldots \ldots \ldots \ldots \ldots \ldots \ldots \ldots \ldots$

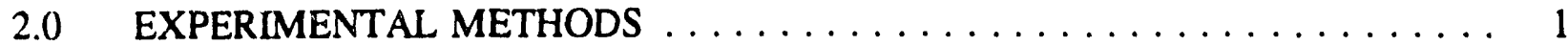

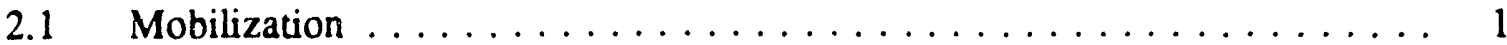

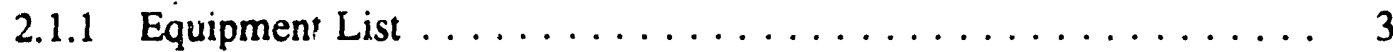

2.1.2 Decontamination Procedures .................. 4

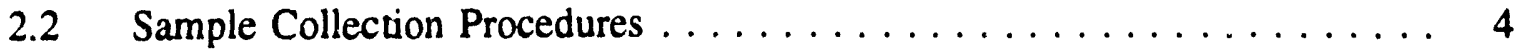

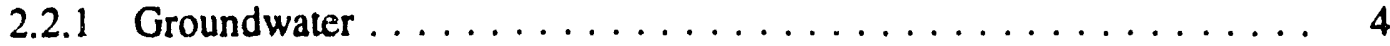

2.2 .2 Surface Water Sampling $\ldots \ldots \ldots \ldots \ldots \ldots$

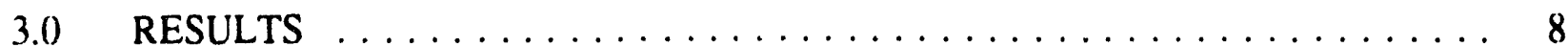

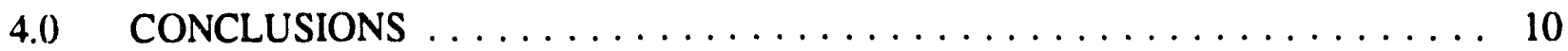

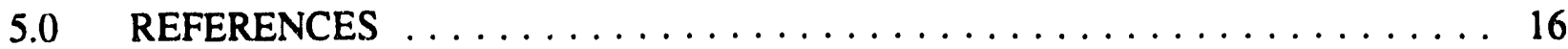

APPENDIX A Chain-of-custody records

APPENDIX B Metcalf \& Eddy Surveillance

\section{LIST OF TABLES}

1.1. Sample Location Numbers and SRS Coordinates $\ldots \ldots \ldots \ldots$

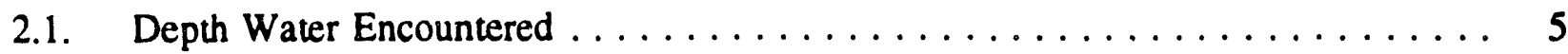

3.1. Water Quality Parameters Measured in the Field . . . . . . . . . . . . 9

4.1. Summary of Conductivity Measurements $\ldots \ldots \ldots \ldots \ldots \ldots$

4.2. Summary of $\mathrm{pH}$ Measurements $\ldots \ldots \ldots \ldots \ldots \ldots \ldots \ldots \ldots \ldots$ 
Four Mile Creek

Semi-Annual Sampling Report

July 1992 Sampling Event

Submitted October 14, 1992

\section{LIST OF FIGURES}

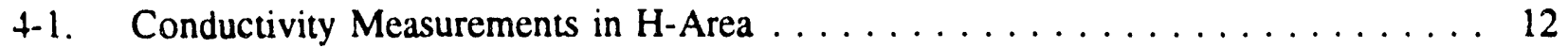

4-2. Conductivity Measurements in F-Area $\ldots \ldots \ldots \ldots \ldots \ldots \ldots$

4-3. $\mathrm{pH}$ Measurements in $\mathrm{H}-$ Area $\ldots \ldots \ldots \ldots \ldots \ldots \ldots \ldots \ldots \ldots$

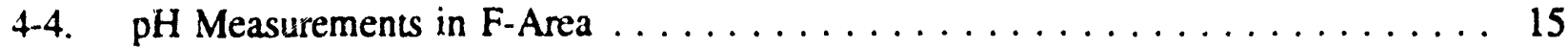


Four Mile Creek

Semi-Annual Sampling Report

July 1992 Sarnpling Event

Submitted October 14, 1992

\subsection{INTRODUCTION}

From 1955 to 1988 low-level radioactive wastewater generated by chemical separation processes within the General Separations Area (GSA) were discharged to seepage basins in the F and H Areas of the Savannah River Site (SRS). These basins were designed to permit the infiltration of the process wastewaters. As wastewater percolated downward through the basins, chemical and radioactive constituents were retained or delayed in the subsoils.

An extensive study aimed at characterizing the groundwater seeping into Four Mile Creek and its associated seepline was conducted in 1988 and 1989 (Haselow et al. 1990). Results of this study suggested that contaminants leaching from the $\mathrm{F}$ and $\mathrm{H}$ Area seepage basins were impacting the Four Mile Creek wetland system. The seepage basins were closed in 1988 and capped and sealed in 1990. This effectively eliminated the hydraulic head driving the migration of contaminants from the basins. It has been hypothesized that, after the elimination of the head, annual rainfall amounts would be sufficient to dilute and flush out contaminants remaining in the subsoils and groundwaters beneath the basins. Westinghouse Savannah River Company has designed a semi-annual sampling and analytical program for the Four Mile Creek (FMC) seepline and stream water to test the hypothesis.

Twelve (12) secpline water and four (4) stream water sampling locations are included in the semi-annual monitoring. These sampling locations include three (3) background locations. Sampling locations were selected by WSRC based on previous sampling results. Sampling location numbers and SRS coordinates are presented in Table 1.1.

The first of the three scheduled semi-annual sampling events took place from July 20,1992 through July 29, 1992. This report summarizes the results of the field monitoring obtained during this event and presents a brief comparison to previous data.

\subsection{EXPERIMENTAL METHODS}

\subsection{Mobilization}

Labeled sample bottles, with preservatives added as necessary, "blue ice", and coolers were provided by the following pairs of subcontracted analytical laboratories: General Engineering Laboratories (non-radiological analyses)/Environmental Physics(radiological analyses); and Roy F. Weston (non-radiological analyses)/Clemson Technical Center(radiological analyses). Additional bottles for on-site analysis of total activity were supplied by the WSRC-EMS Radiological Laboratory. WSRC provided chain-of-custody forms and packaging materials. 
Four Mile Creek

Semi-Annual Sampling Report

July 1992 Sampling Event

Submitted October 14, 1992

Table 1.1. Sample Location Numbers and SRS Coordinates

\begin{tabular}{lll} 
Seepline & \multicolumn{2}{c}{ SRS Coordinates } \\
& North & East \\
H-Area & & \\
HSP008 & 71005 & 56990 \\
HSP029 & 71278 & 56257 \\
HSP043 & 71644 & 55722 \\
HSP060 & 71629 & 55190 \\
HSP092 & 72672 & 54129 \\
& & \\
F-Area & & \\
FSP012 & 73602 & 49644 \\
FSP032 & 73367 & 50258 \\
FSP047 & 73609 & 50607 \\
FSP204 & 73281 & 48801 \\
FSP290 & 73160 & 46865 \\
& & \\
Background & & \\
BG001 & Seepline \\
BG002 & Seepline & \\
BG003 & Stream water \\
Stream Sites & & \\
FMC0001H & & \\
FMC0002H & 70350 & 57050 \\
FMC0001F & 72600 & 53000 \\
& 72200 & 43900 \\
& & \\
\hline
\end{tabular}

${ }^{1}$ The locations of background samples were within the grid identified by Site Use Grid Maps 13 and 14 as $71750 \mathrm{~N}$ and $40000 \mathrm{E}$ and $70000 \mathrm{E}$. The exact location was identified by ESS technical personnel. 
Four Mile Creek

Semi-Annual Sampling Report

July 1992 Sampling Event

Submitted October 14, 1992

The sample bottles needed for one day of sampling were separated by station and carried to the sampling station.

\subsubsection{Equipment List}

The following equipment was used during seepline groundwater sampling:

Rubber gloves

Safety glasses

Clipboard, waterproof pens, waterproof markers

Field data logbook

Chain-of-custody forms

Shipping Orders

Samples bottles

Backpacks

Shovel, post-hole digger, hatchet or axe

Peristaltic pump

Paper and cloth towels

Ziplock bags

Coolers with cool packs

Bubble Pack

Sampling buckets (5-gallon) with lids

Water quality meters ( $\mathrm{pH}$, conductivity, redox)

Silicone (Silastic) tubing

1 one-liter Nalgene bottle for each station sampled

0.45 micron filters and filtering equipment

Tyvek Aprons

The following equipment was used during stream water sampling:

Rubber gloves

Safety glasses

Clipboard, waterproof pens, waterproof markers

Field data logbook

Chain-of-custody forms

Shipping orders

Sample bottles

Backpacks

Paper and cloth towels 
Four Mile Creek

Semi-Annual Sampling Report

July 1992 Sampling Event

Submitted Cctober 14, 1992

Ziplock bags

Coolers with cool packs

Bubble Pack

Water quality meters ( $\mathrm{pH}$, conductivity, redox)

1 one-liter Nalgene bottle for each station sampled

0.45 micron filters and filtering equipment

Life jackets

Hip Boots

Tyvek Aprons

\subsubsection{Decontamination Procedures}

Cleaning and decontamination procedures for all sampling equipment are outlined below. All sampler parts were decontaminated prior to the collection of each sample.

Sampling equipment was first cleaned with Milli- $Q$ water and phosphate-free laboratory detergent (Liquinox) using a brush if necessary to remove particulate matter and surface films. The equipment was then rinsed thoroughly with Milli-Q water. Finally, the equipment was rinsed two times with pesticide-grade methanol solvent and allow to air dry. The dry equipment was wrapped with aluminum foil, when necessary, to prevent contamination during storage or transport.

All decontamination rinse waters were discharged to the ground. The methanol was collected in a pan and allowed to evaporate.

\subsection{Sample Collection Procedures}

\subsubsection{Groundwater}

All sample locations had been permanently marked by WSRC with a 1" schedule 40 PVC stake driven 2 feet below grade. An identification number was written on each PVC stake.

After locating the sampling station, the sampling crew excavated a hole using a decontaminated stainless steel shovel. The hole was excavated within a 3 foot radius of the PVC stake. Water was encountered in f:ach hole at the depths indicated in Table 2.1. The sampling bucket was placed into the hole and covered with a lid. One bucket was set at each location except locations HSP008, HSP043, FSP047 and FSP290 where two buckets were set. The additional bucket was needed in order to collect sufficient water for duplicate and QA samples. 
Four Mile Creek

Semi-Annual Sampling Report

July 1992 Sampling Event

Submitted October 14, 1992

Table 2.1. Depth Water Encountered

LOCATION

H-Area

HSP008

HSP029

HSP043

HSP060

HSP092

\section{F-Area}

FSP012

FSP032

FSP047

FSP204

FSP290

Background

BG001

BG002

\section{WATER DEPTH}

$$
\begin{array}{ll}
8 & \text { inches } \\
2 & \text { inches } \\
2 & \text { feet } \\
2 & \text { inches } \\
1.5 \text { feet }
\end{array}
$$

2 feet

8 inches

Data not available

Surface

1 foot

7 inches

8 inches 
Four Mile Creek

Semi-Annual Sampling Report

July 1992 Sampling Event

Submitted October 14, 1992

The buckets were set out one day prior to sample collection in order to allow the sediment in the water to settle. The time between setting the bucket and sample collection was recorded in the field notebook.

The $40 \mathrm{ml}$ GCMS/VOA vials and the 1-liter sample bottle, for water to be filtered for metals analysis, were filled first by dipping them into the bucket. This was done in such a manner as to avoid disturbance of the sediment. The VOA vial was filled completely so that no air bubbles were present in the sample.

The remaining samples were collected by pumping the water from the bucket to the remaining sample jars through silastic (silicone) tubing using a peristaltic pump powered by a 12-volt battery. New tubing was used for each sample location. The new tubing was flushed for 20 seconds with water from the bucket before the sampling crew collected the sample.

Samples collected for metals analysis were filtered in the field through a 0.45 micron membrane filter (to remove fine particulate matter from the water being analyzed). Thi, filtering occurred within 4 hours of sample collection. The filtering apparatus was flushed with deionized or distilled water between filtering each sample.

Samples collected on July 22, 1992 were very turbid, possibly due to a rainfall event that occurred the previous evening. The turbidity caused filtering problems and increased field processing time. As a result, the field crew collected approximately one half the volume of water required for metals analysis for the duplicate sample at station HSPO43 and were unable to collect the metals sample for QA-1S.

The $\mathrm{pH}$, conductivity, and redox potential of the water at each location were measured at the time of sampling. These readings were taken directly from the water collected in the 5 gallon bucket and recorded in the field data logbook. The probes were rinsed with DI water prior to taking these measurements.

Blue ice was used to keep the samples cool from the time of sampling until they were received at the analytical laboratory.

At each sar:pling location, a $250 \mathrm{ml}$ plastic sample container was filled with the water and sent to the WSRC EMS Radiological Laboratory to determine the total activity in the samples. These data were used to determine the packaging and shipping requirements of the specific samples.

Duplicate samples were collected at both HSP043 and FSP047 and sent to General 
Four Mile Creek

Semi-Annual Sampling Report

July 1992 Sampling Event

Submitted October 14, 1992

Engineering/Environmental Physics and Roy F. Weston/Clemson for QA/QC purposes. A triplicate sample was collected from HSP008. This triplicate sample consisted of HSPOO8 sent to General Engineering/Environmental Physics; QA-1S sent to General

Engineering/Environmental Physics and QA-1S sent to Roy F. Weston/Clemson. A triplicate sample was collected from FSP290. This triplicate sample consisted of FSP290 sent to General Engineering/Environmental Physics; QA-3S sent to General Engineering/Environmental Physics and QA-3S sent to Roy F. Weston/Clemson.

Two trip blanks were included for the semi-annual sampling event (QA-2S and QA-4S).

Two equipment rinsate samples (QA-3 and QA-4) were collected on July 27, 1992.

Two samples of Milli-Q water, one from the source (QA-1) and one from the field carboy (QA-2), were collected $n$ July 27, 1992 and sent to General Engineering.

At the end of each day, the samples were transported to the Health Protection office in the Central Shops area where the outside of the containers were scanned for radioactivity. The purpose of this scan was to identify any radiological health hazards associated with handling the samples. The samples were then transported to the laboratory at 704B where they remained until cleared for shipment.

\subsubsection{Surface Water Sampling}

Collection of the surface water samples was performed by dipping the sample container directly into the stream water. This collection method minimizes alteration of the sample. Also, the potential for sample cross contamination through the use of poorly decontaminated sampling equipment is eliminated. Sampling personnel wore hip boots and gloves to minimize exposure to potential contaminants.

The sample bottles to be used at each location were removed from the coolers and the bottle labels were completed with waterproof markers or ball point pens.

Surface grab samples were collected in the middle of the stream from the top of the water column. The container was placed into the water with the mouth of the container facing upstream such that water flowed directly into the container. Care was taken when opening and filling the bottles since some of the bottles contained carefully measured amounts of chemical preservatives.

All containers, except the VOA vials, were filled to the shoulder with water. VOA vials were 
Four Mile Creek

Semi-Annual Sampling Report

July 1992 Sampling Event

Submitted October 14, 1992

filled completely and capped so that no air bubbles were present in the sampie. Water collected for metals analysis was filtered in the field prior to preservation. The filled sample containers were capped tightly and placed in a plastic ziplock bag. The samples were placed in coolers and kept cool.

The in-situ pH, conductivity and redox potential of the stream was measured and recorded in field notebook.

Evidence of sample collection, shipment, laboratory receipt and laboratory custody until sample disposal must be documented to ensure the sample traceability scheme.

Documentation was accomplished through a chain-of-custody record that contains the necessary information for individual sample identification and lists the individuals responsible for sample collection, shipment, and receipt along with nesessary signatures and dates. Completed chain-of-custody forms for this sampling event are presented in Appendix A.

\subsection{RESULTS}

The $\mathrm{pH}$, conductivity, and redox potential measurements collected in the field are summarized in Table 3.1. The $\mathrm{pH}$ readings for the $\mathrm{H}$-Area se pline samples ranged from 4.80 to 6.32 with an average value of 5.72. The $\mathrm{pH}$ readings for the F-Area seepline samples ranged from 4.10 to 5.38 with an average value of 4.96 . The average $\mathrm{pH}$ of the background seepline samples was 4.91 . The conductivity readings for the seepline samples in the H-Area ranged from $33 \mu \mathrm{mhos} / \mathrm{cm}$ to $237 \mu \mathrm{mhos} / \mathrm{cm}$ with an average value of $139 \mu \mathrm{mhos} / \mathrm{cm}$. The conductivity readings for the seepline samples in the F-Area ranged from $46 \mu \mathrm{mhos} / \mathrm{cm}$ to 277 $\mu \mathrm{mhos} / \mathrm{cm}$ with an average value of $122 \mu \mathrm{mhos} / \mathrm{cm}$. The average conductivity of the vackground seepline samples was $30 \mu \mathrm{mhos} / \mathrm{cm}$. The redox potential readings for the seepline samples in the H-Area ranged from $107 \mathrm{mV}$ to $205 \mathrm{mV}$ with an average value of $158 \mathrm{mV}$. The redox potential readings for the seepline samples in the F-Area ranged from $53 \mathrm{mV}$ to $227 \mathrm{mV}$ with an average value of $148 \mathrm{mV}$. The average redox potential of the background seepline samples was $200 \mathrm{mV}$.

The $\mathrm{pH}$ readings for the stream samples ranged from 6.67 to 7.19 with an average value of 6.87. The $\mathrm{pH}$ of the background stream sample was 5.80. The conductivity readings for the stream samples ranged from $70 \mu \mathrm{mhos} / \mathrm{cm}$ to $94 \mu \mathrm{mhos} / \mathrm{cm}$ with an average value of 83 $\mu \mathrm{mhos} / \mathrm{cm}$. The conductivity of the background stream sample was $20 \mu \mathrm{mhos} / \mathrm{cm}$. The redox potential readings for the stream samples ranged from $136 \mathrm{mV}$ to $178 \mathrm{mV}$ with an average value of $150 \mathrm{mV}$. The redox potential of the background stream sample was $-13 \mathrm{mV}$. 
总皆总总 可

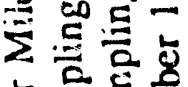

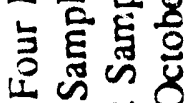
震登总

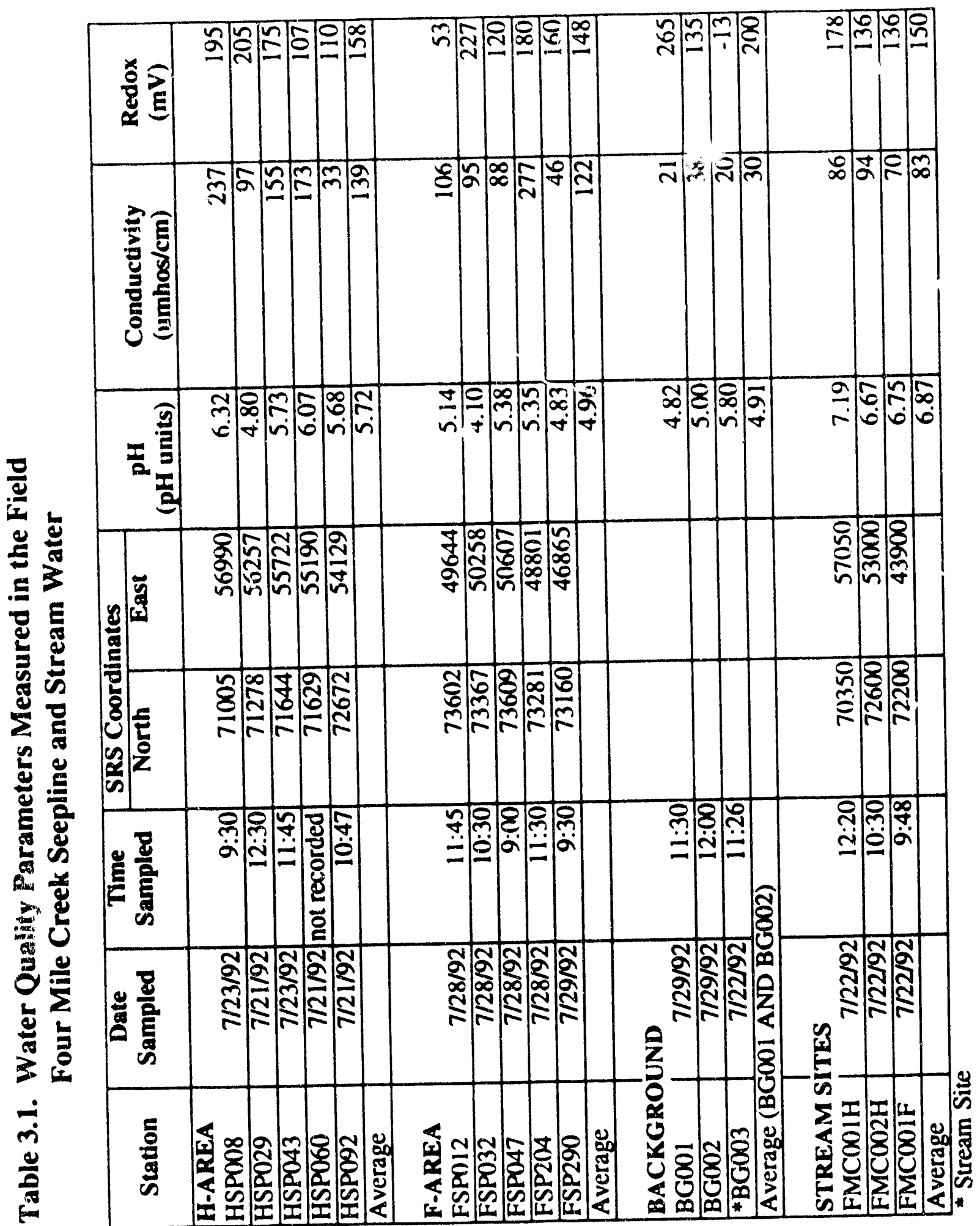


Four Mile Creek

Semi-Annual Sampling Report

July 1992 Sampling Event

Submitted October 14, 1992

The conductivity and $\mathrm{pH}$ of the seepline water was measured previously in March of 1989 (Haselow et al., 1990) and in May of 1992 (Dixon et al., 1992). A summary of this previous data and the current data is presented in Tables 4.1 and 4.2 and shown graphically in Figures 4-1 through 4-4.

Figures 4-1 and 4-2 illustrate the conductivity measurements collected from the H-Area and the F-Area, respectively. A general trend of decreasing conductivity is evident in the H-Area. This decreasing trend is not seen in the F-Area. The conductivity measurements at sample locations FSP032 and FSP204 in the F-Area show a decreasing trend in conductivity. The measurements at sample location FSP012 show an increasing trend The measurements at sample locations FSP047 and FSP290 show no decreasing or increasing trend. The average background conductivity of the seepline water collected during this sampling event was 29.5 $\mu \mathrm{mhos} / \mathrm{cm}$. Ninety-six percent of the data presented in Table 4.1 exceeds this background conductivity value.

Figures 4-3 and 4-4 illustrate the $\mathrm{pH}$ measurements collected from the $\mathrm{H}$. Area and the FArea, respectively. No specific trend is evident in either of these figures. The average background $\mathrm{pH}$ of the seepline water collected during this sampling event was 4.91. Sixtyfive percent of the data presented in Table 4.2 has a $\mathrm{pH}$ measurement which is greater than 4.91 .

The background stream measurement for $\mathrm{pH}(5.80)$ and conductivity (20 umhos/cm) was exceeded in all of the downgradient stream samples.

There is no historical data available on redox potential, thus, we can not assess any possible trends at this time. However, the average background redox potential of the seepline water collected during this sampling event was $200 \mathrm{mV}$. Twenty percent of the data presented in Table 3.1 has a redox potential measurement which is greater than $200 \mathrm{mV}$. The redox potential of the background stream water was $-13 \mathrm{mV}$. The redox potential of the down stream sites were significantly higher than $-13 \mathrm{mV}$.

Metcalf \& Eddy conducted a surveillance of the sampling procedures to verify that sampling was being conducted in accordance with the approved task specific Quality Assurance Project Plan. The results of this surveillance is provided in Appendix B.

\subsection{CONCLUSIONS}

The average $\mathrm{pH}$ and conductivity values measured during this field event for the F-Area seepline samples, the $\mathrm{H}$-Area seepline samples, and the stream samples are higher than the

$$
\text { (.text intinued in p/6) }
$$


Four Mile Creek Semi-Annual Sampling Report July 1992 Sampling Event Submitted October 1992

TABLE 4.1. SUMMARY OF CONDUCTIVITY MEASUREMENTS

\begin{tabular}{|r|r|r|r|r|r|}
\hline \multirow{2}{*}{ H-AREA } & \multicolumn{6}{|c|}{ CONDUCTIVITY (umhos/cm) } \\
\cline { 2 - 7 } & HSP008 & HSP029 & HSP043 & HSP060 & HSP092 \\
\hline Mar-89 & 556 & 257 & 413 & 473 & ND \\
\hline May-92 & 334 & 234 & 294 & 274 & ND \\
\hline Jul-92 & 237 & 97 & 155 & 173 & 33 \\
\hline
\end{tabular}

\begin{tabular}{|r|r|r|r|r|r|}
\hline F-AREA & \multicolumn{7}{|c|}{ CONDUCTIVITY (umhos/cm) } \\
\cline { 2 - 7 } & FSP012 & FSP032 & FSP047 & FSP204 & FSP290 \\
\hline Mar-89 & 30 & 174 & 52 & 895 & 49 \\
\hline May-92 & 58 & 138 & 125 & 311 & 28 \\
\hline Jul-92 & 106 & 95 & 88 & 277 & 46 \\
\hline
\end{tabular}

TABLE 4.2. SUMMARY OF PH MEASUREMENTS

\begin{tabular}{|c|c|c|c|c|c|}
\hline \multirow[t]{2}{*}{ H-AREA } & \multicolumn{5}{|c|}{$\mathbf{p H}$} \\
\hline & HSPOO8 & HSP029 & HSP043 & HSPO60 & HSPO92 \\
\hline Mar-89 & 5.7 & 5.2 & 5.3 & 5.9 & ND \\
\hline May-92 & 5.6 & 6.1 & 6.2 & 5.6 & $\mathrm{ND}$ \\
\hline Jul-92 & 6.32 & 4.8 & 5.73 & 6.07 & 5.68 \\
\hline
\end{tabular}

\begin{tabular}{|r|r|r|r|r|r|}
\hline F-AREA & \multicolumn{7}{|c|}{ pH } \\
\cline { 2 - 7 } & FSP012 & FSP032 & FSP047 & FSP204 & FSP290 \\
\hline Mar-89 & 5.3 & 5 & 4.7 & 4.4 & 3.6 \\
\hline May-92 & 5.4 & 4.3 & 4.6 & 4.4 & 4.8 \\
\hline Jul-92 & 5.14 & 4.1 & 5.38 & 5.35 & 4.83 \\
\hline
\end{tabular}




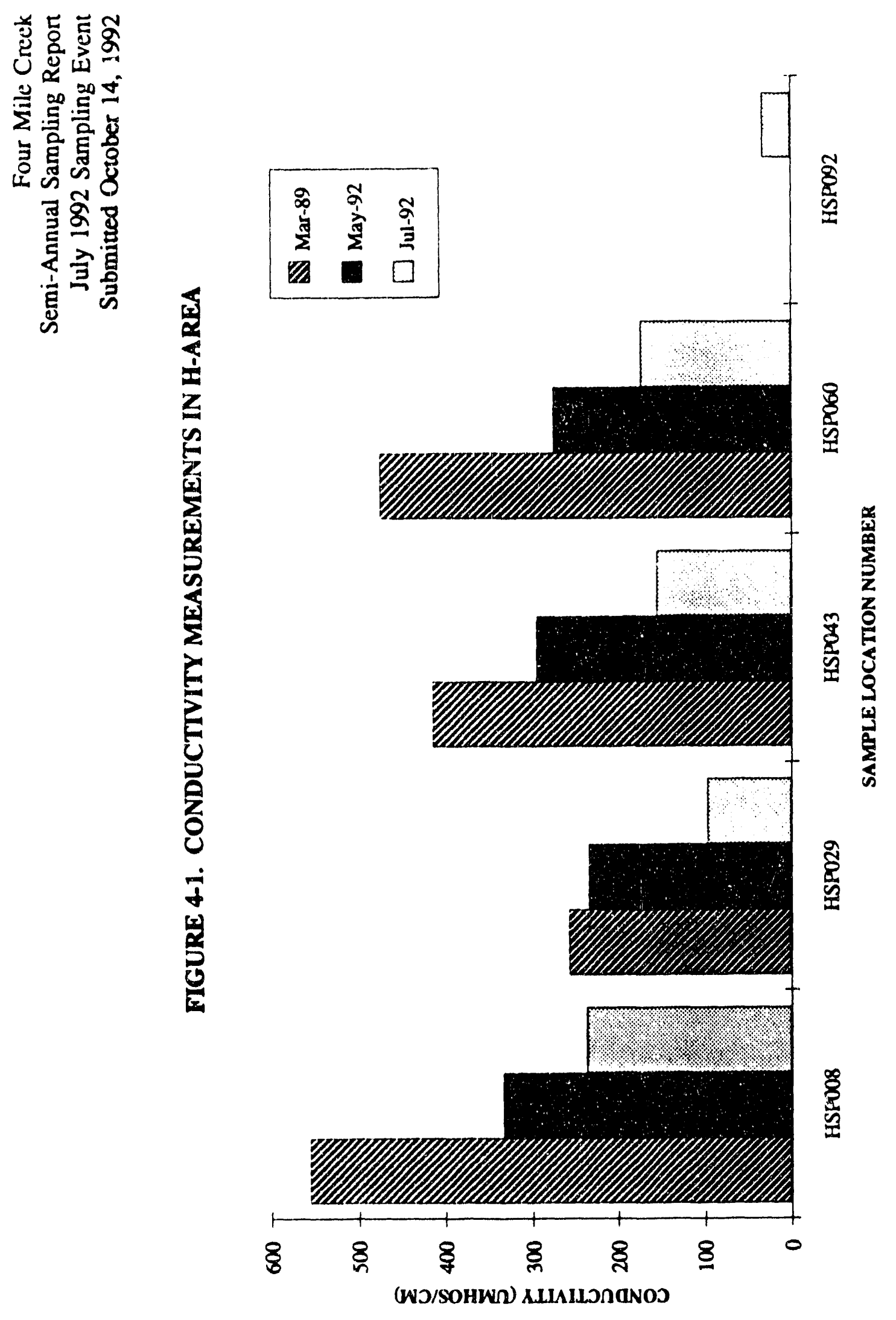



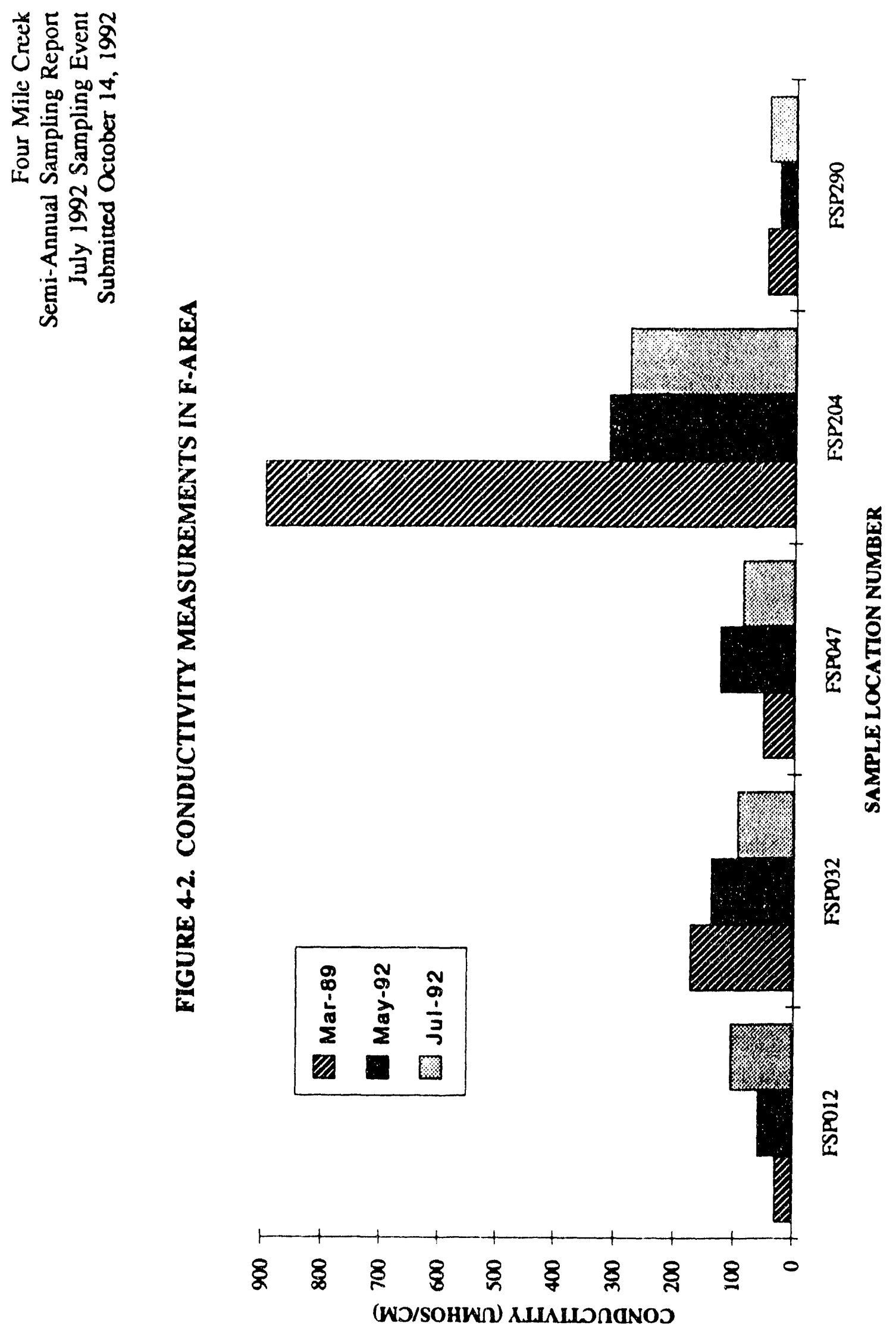

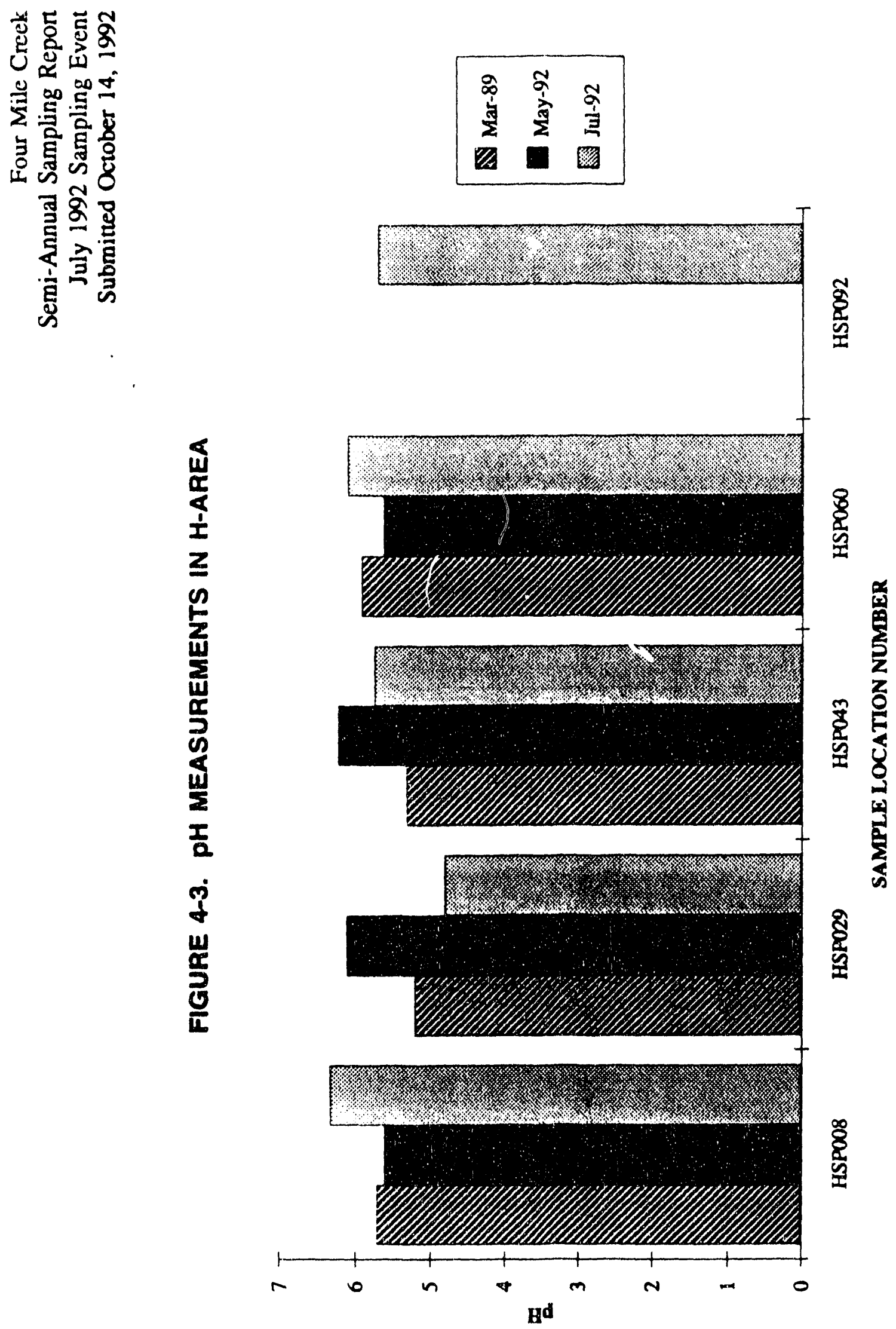

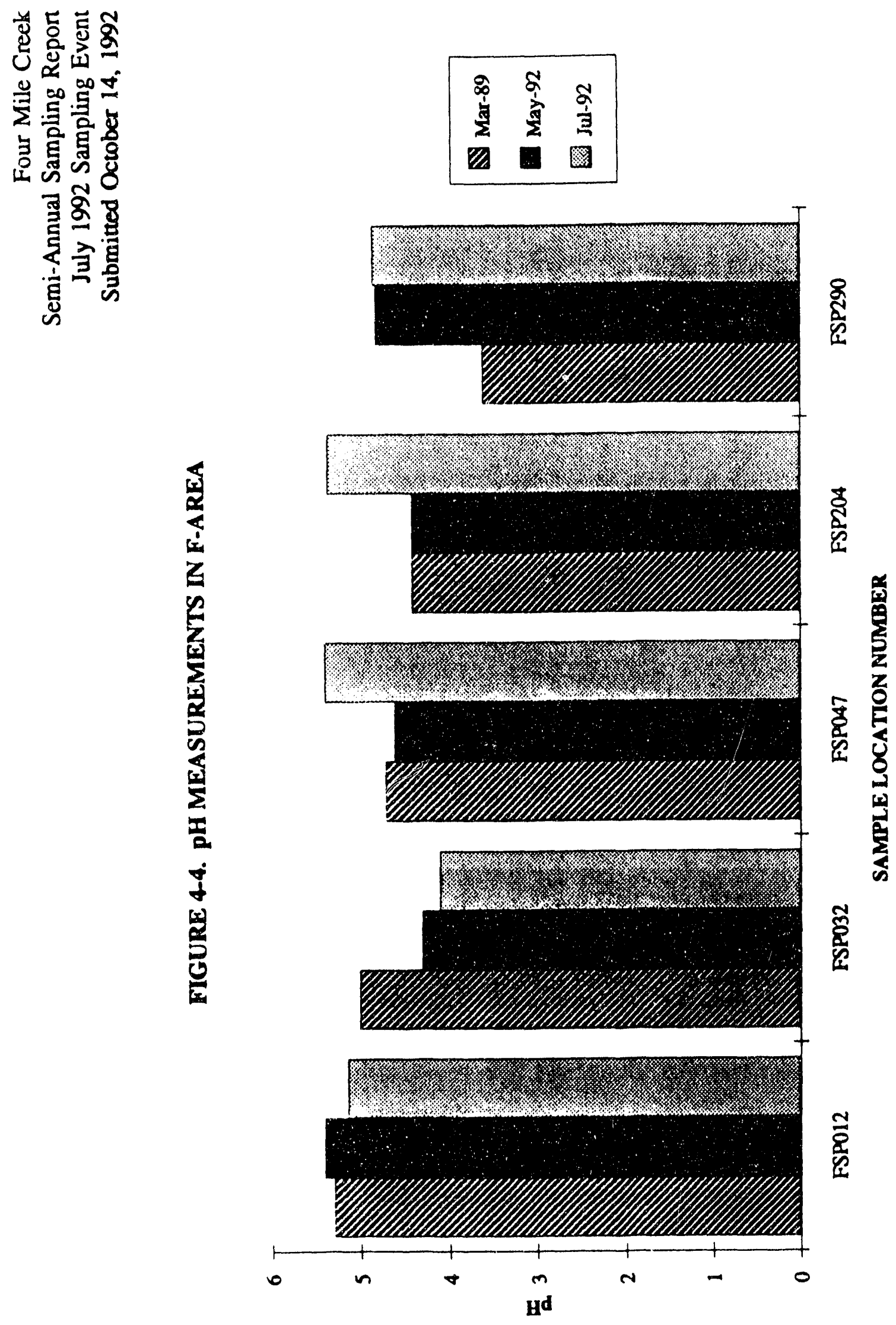
Four Mile Creek

Semi-Annual Sampling Report

July 1992 Sampling Event

Submitted October 14, 1992

average $\mathrm{pH}$ and conductivity of the background seepline and stream water samples. The average redox potential of both the F-Area and the H-Area seepline samples is less than the average redox potential of the background seepline sample. However, the redox potential of the background stream water was lower than the average redox potential of the downgradient stream samples.

Historical trends indicate decreasing conductivity measurements in the H-Area seepline samples. No trends are evident in the conductivity measurements for the F-Area seepline.

Historical $\mathrm{pH}$ measurements in both the F-Area and $\mathrm{H}$-Area seepline samples show no general trends. There is no historical information available regarding the redox potential of the seepline or stream water samples.

\subsection{REFERENCES}

Haselow, J.S., M. Harris, B.B. Looney, N.V. Halverson, J.B. Gladden. 1990. Analysis of Soil and Water at the Four Mile Creek Seepline Near the F and $H$ Area of the SRS (U). WSRCRP-90-0591, Savannah River Laboratory, Aiken, South Carolina.

Dixon, K.l. and V.A. Rogers. Results of the First Quarter Tritium Survey of the F-and HArea Seeplines: May 1992 (U). WSRC-TR-92-304, Savannh River Technology Center, Aiken, South Carolina. 
APPENDIX A

Chain-of-custody records 


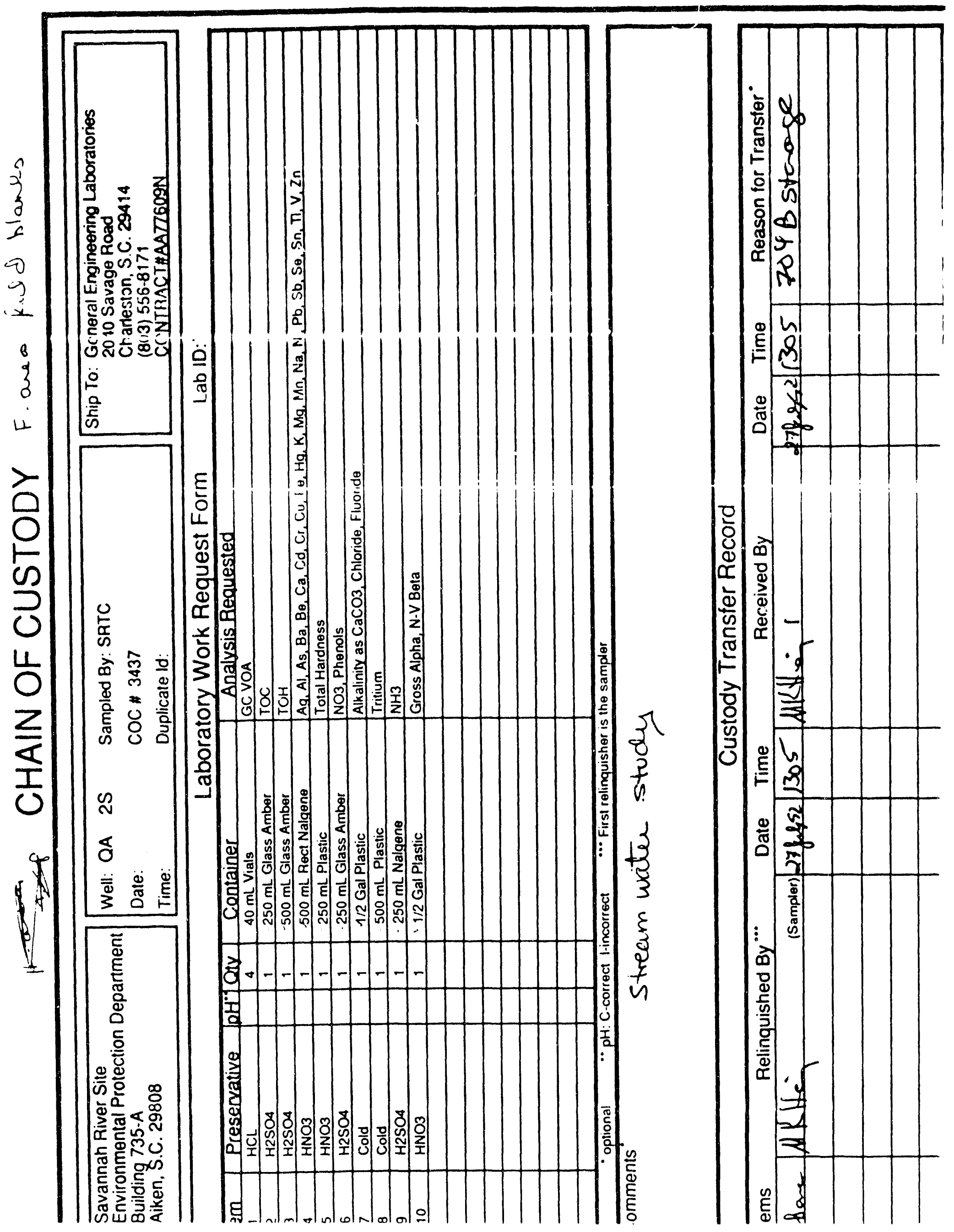




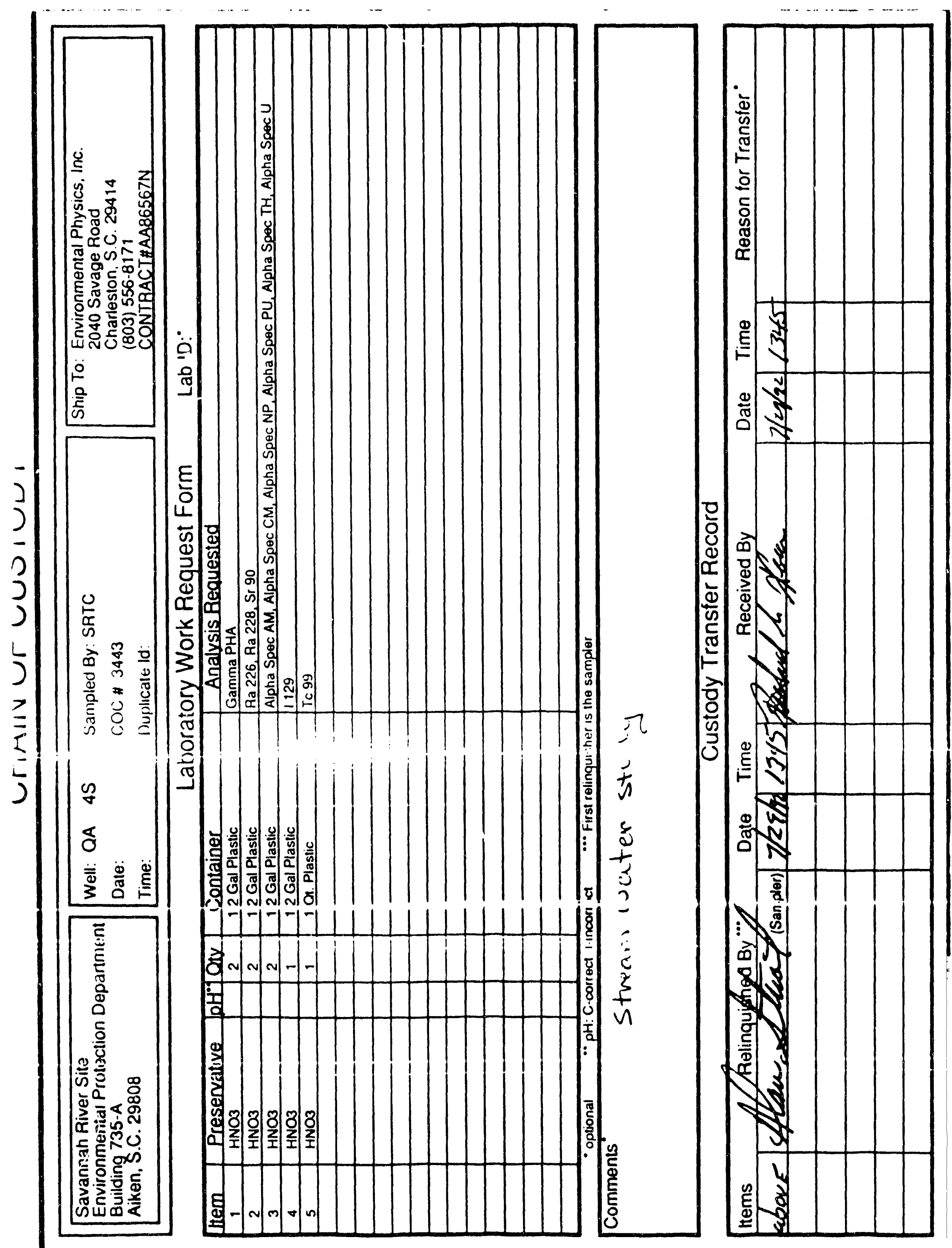




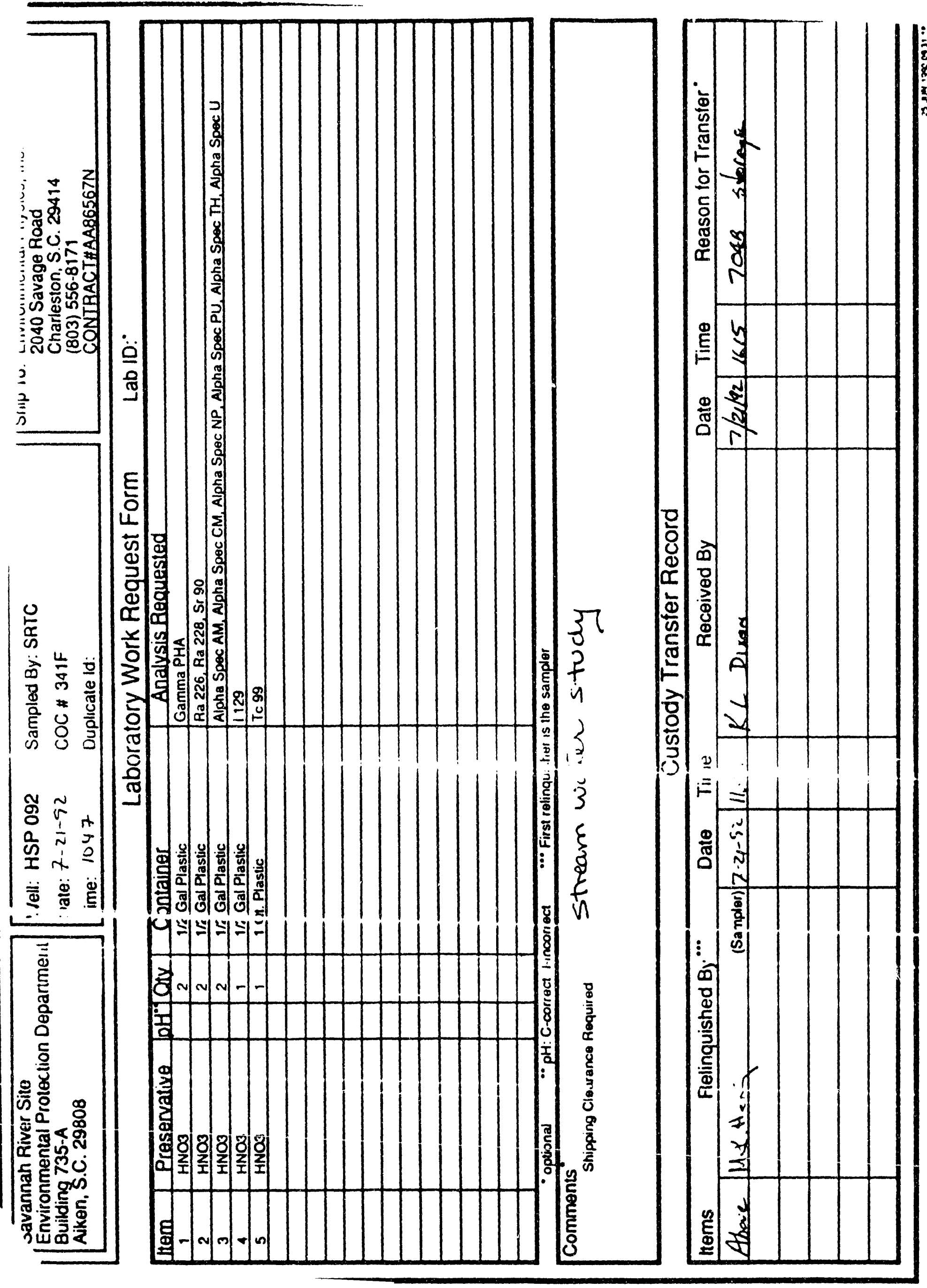




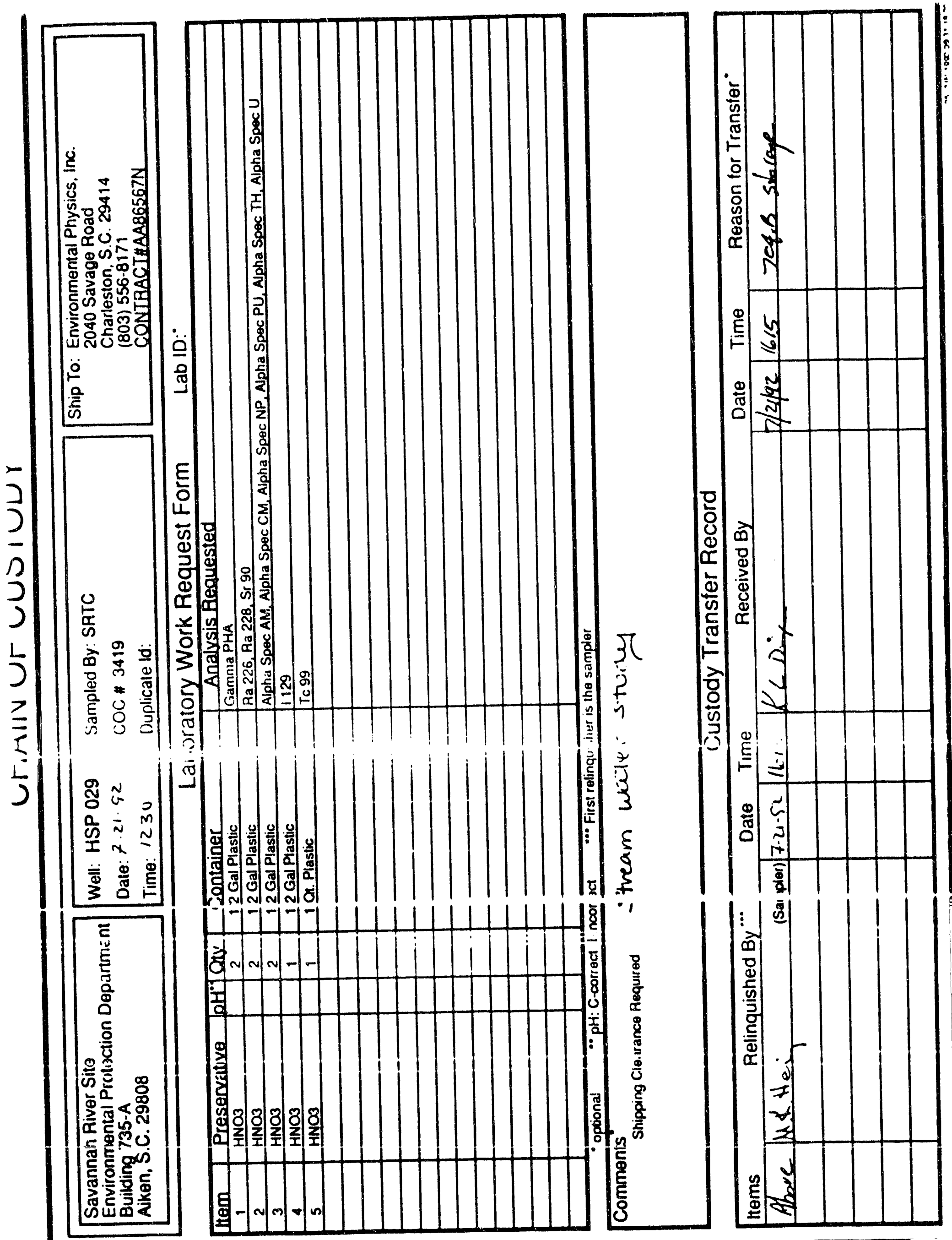




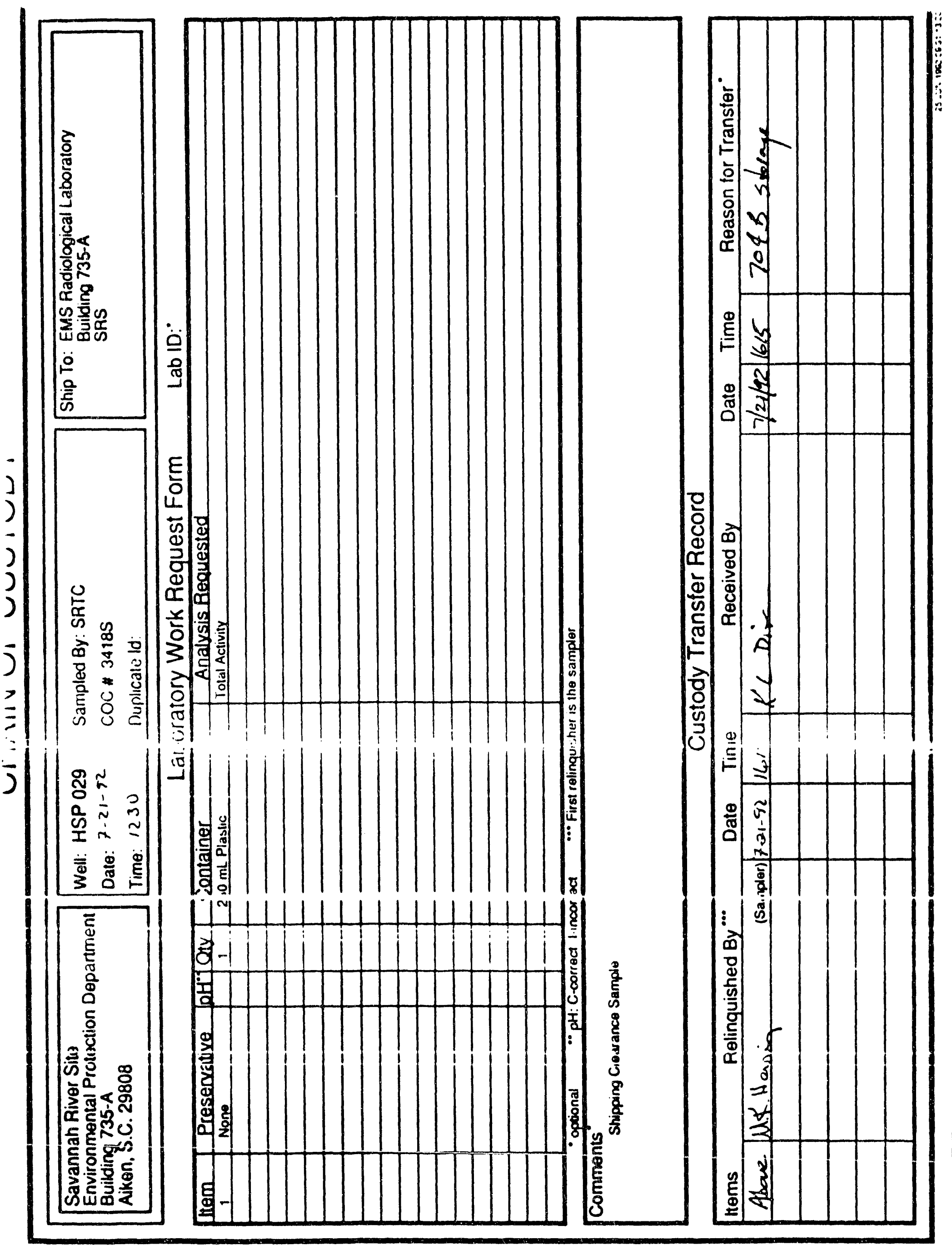




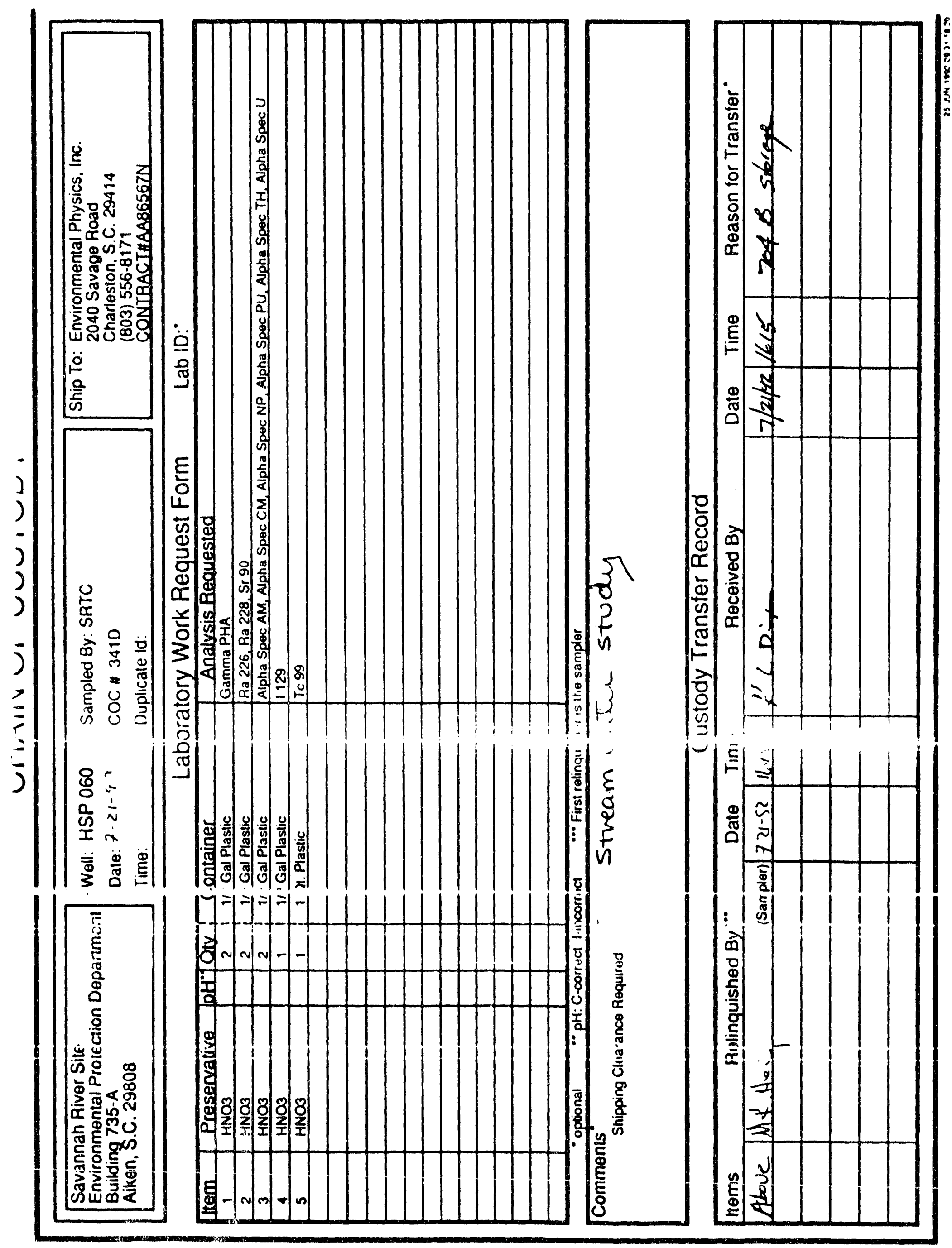




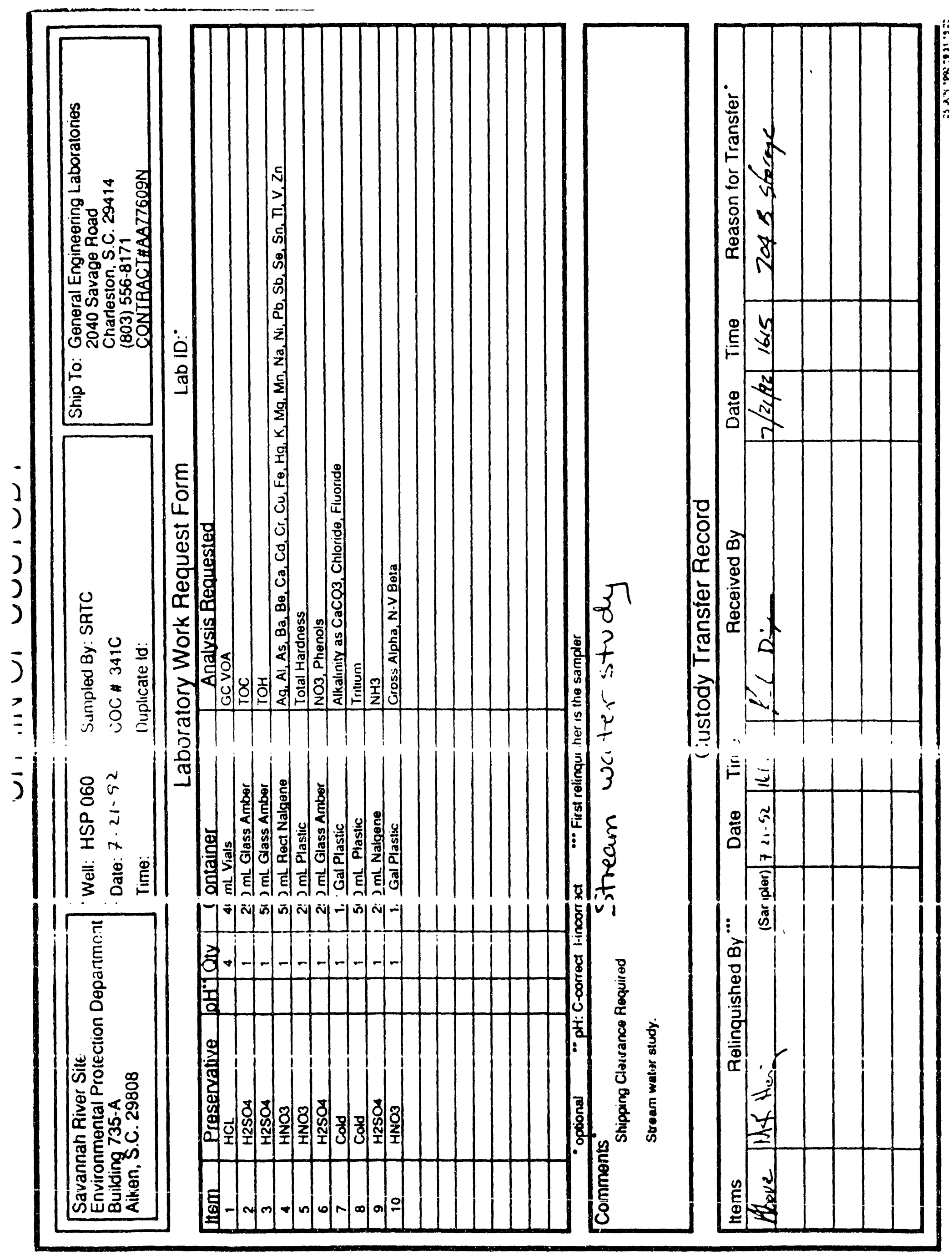




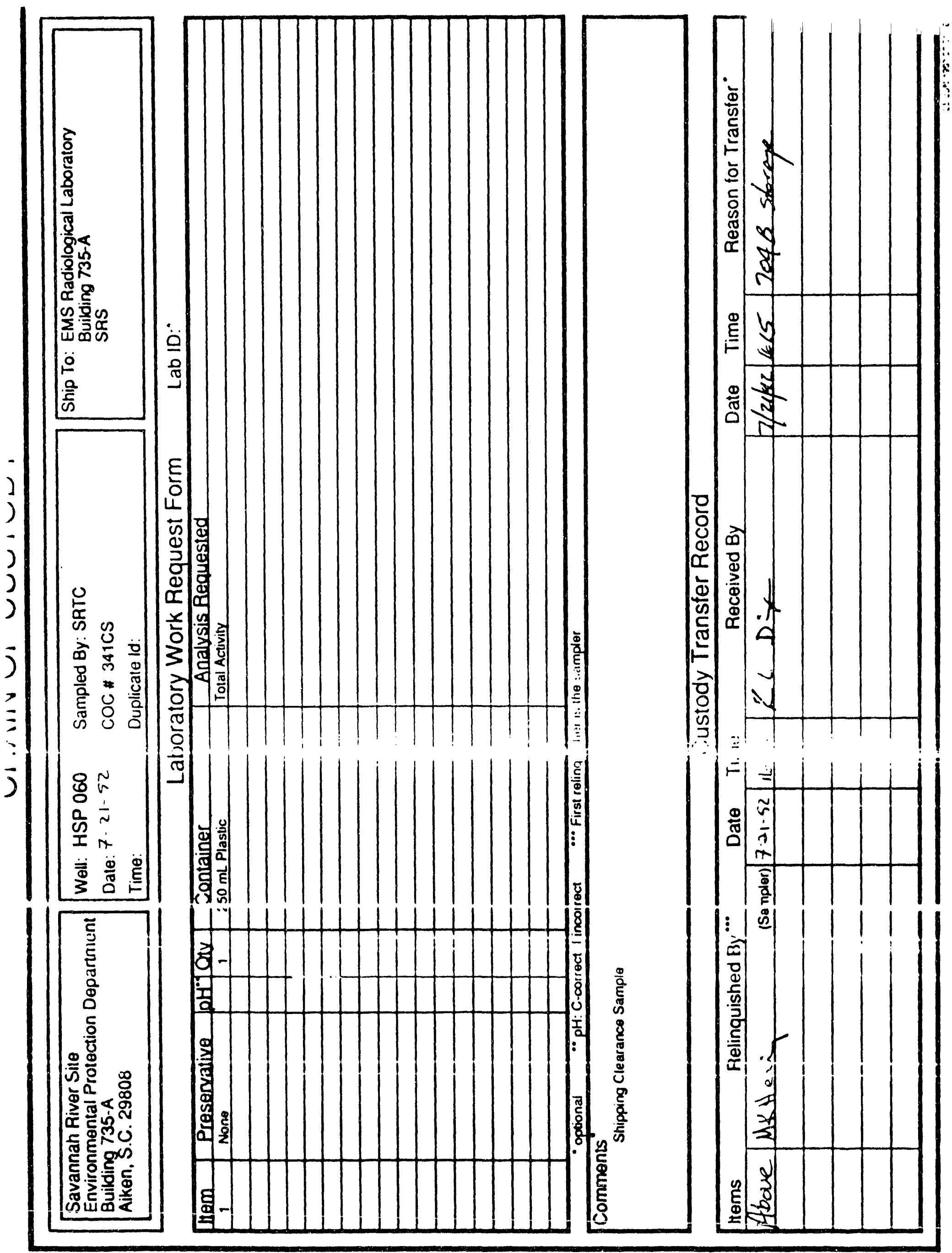




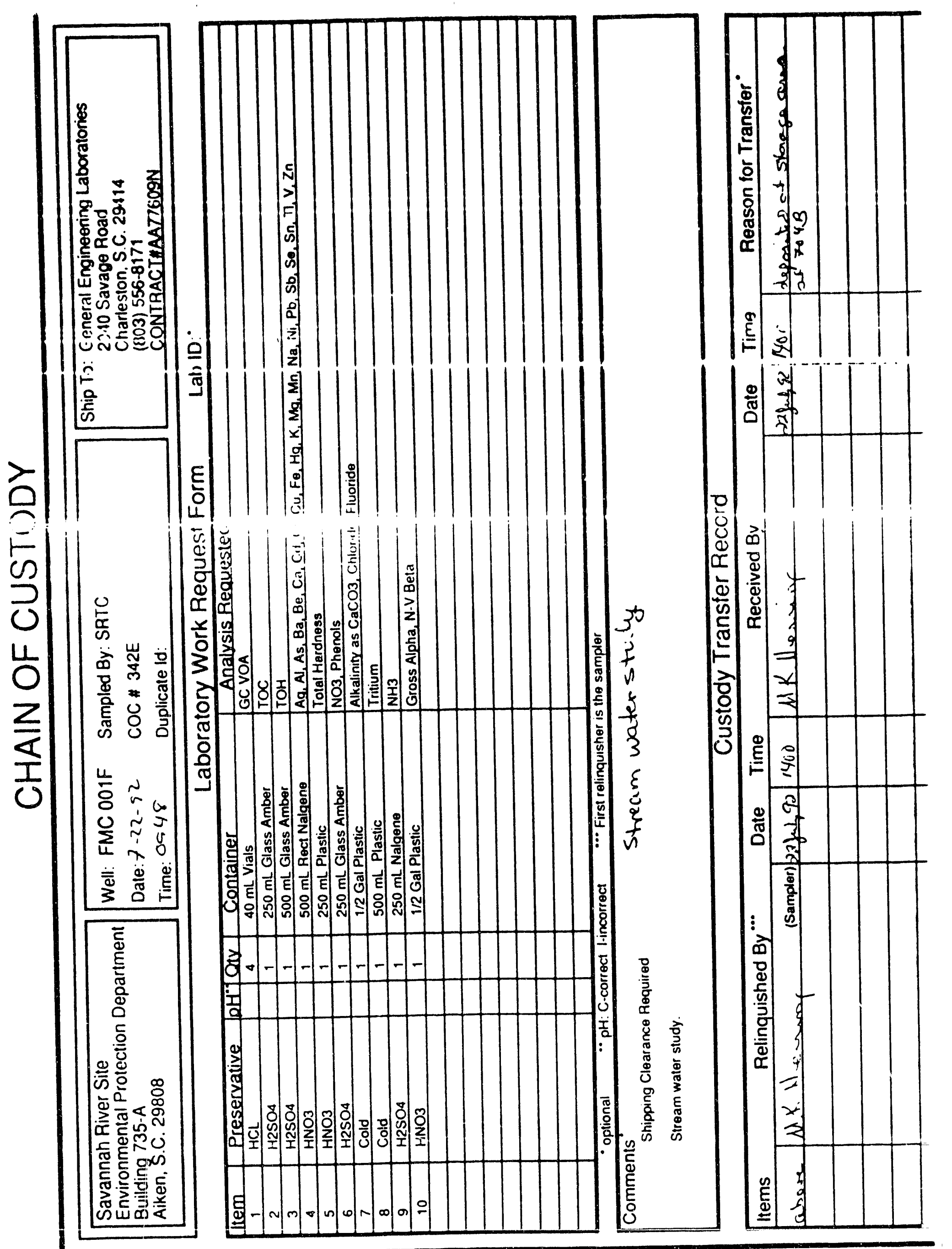




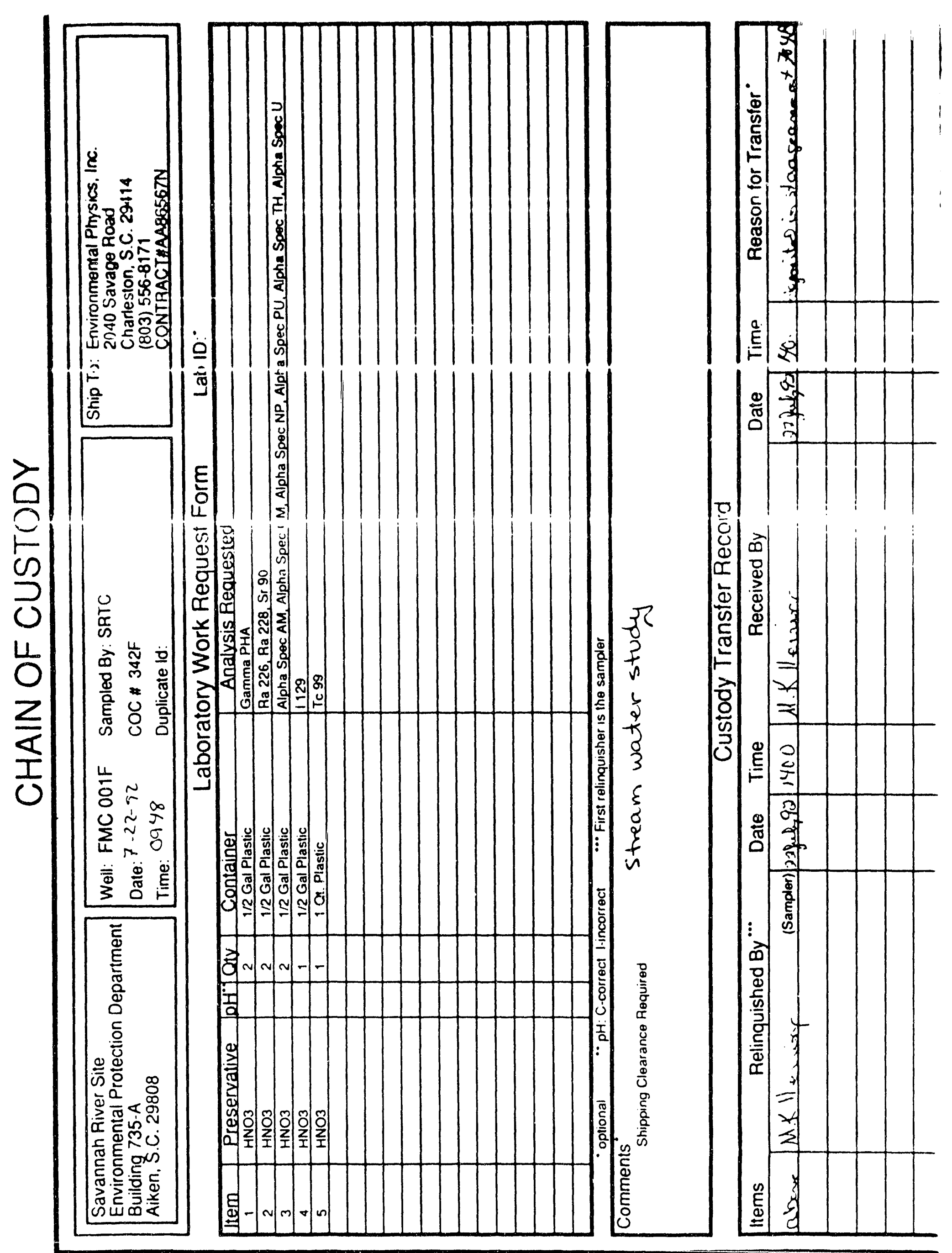




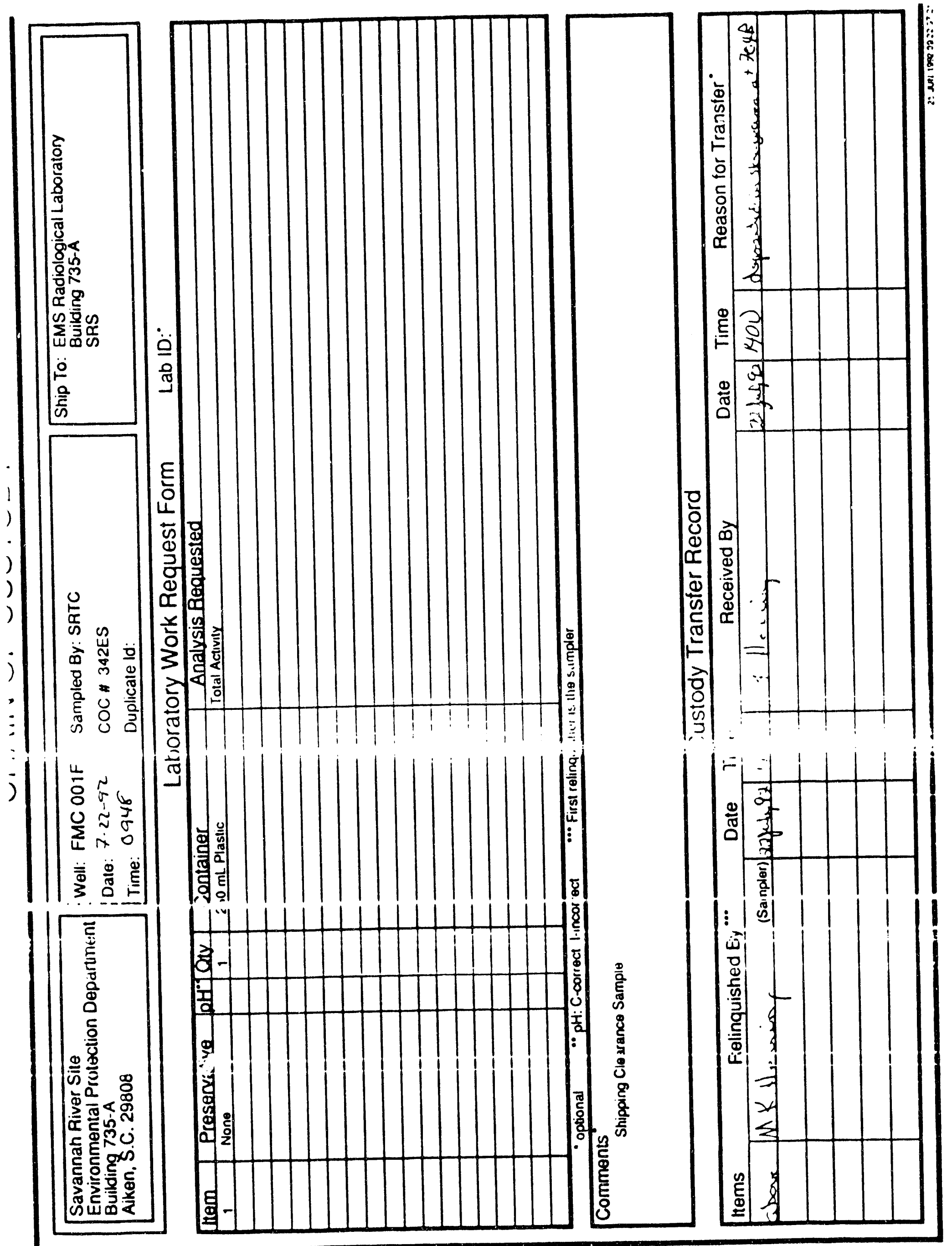




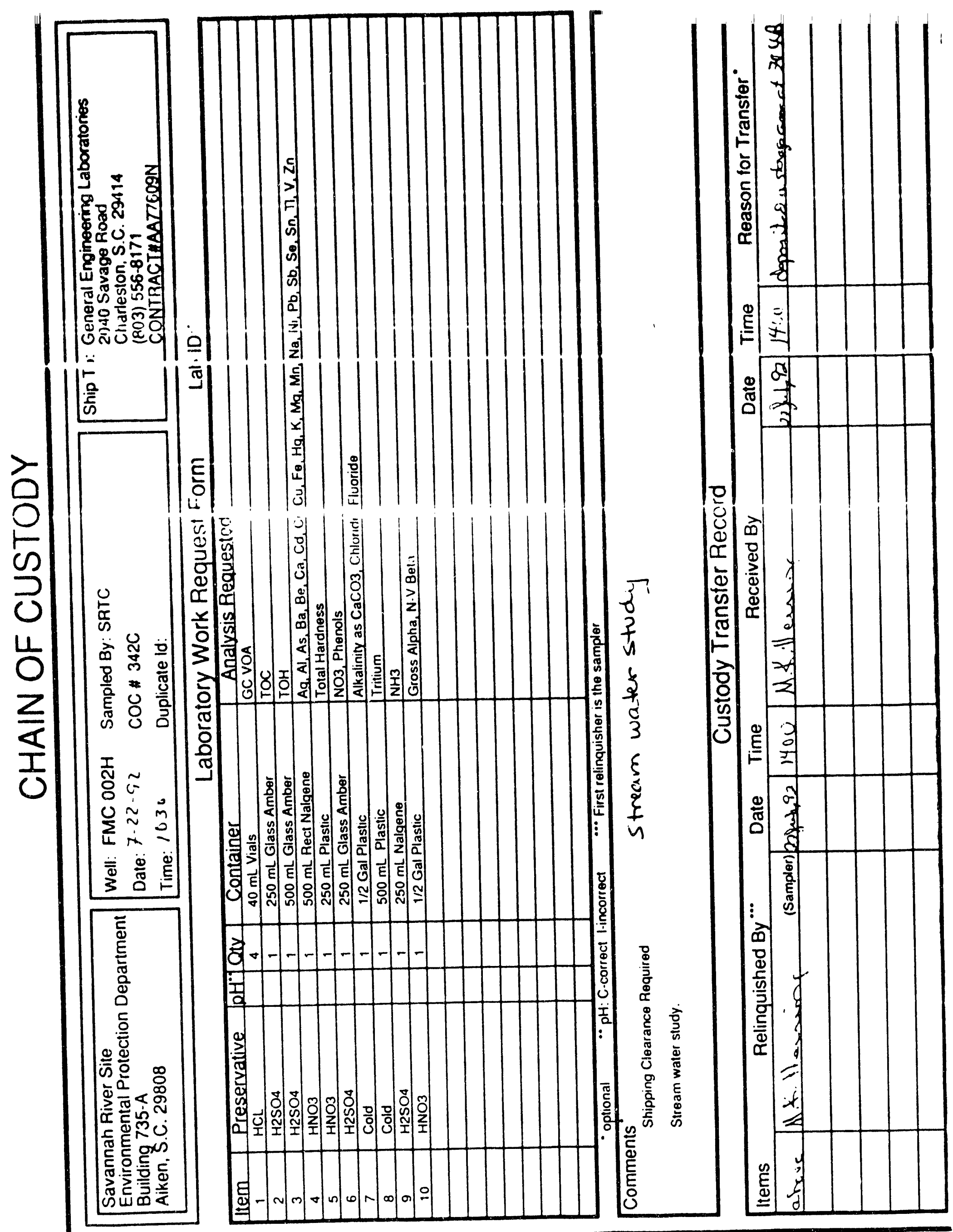




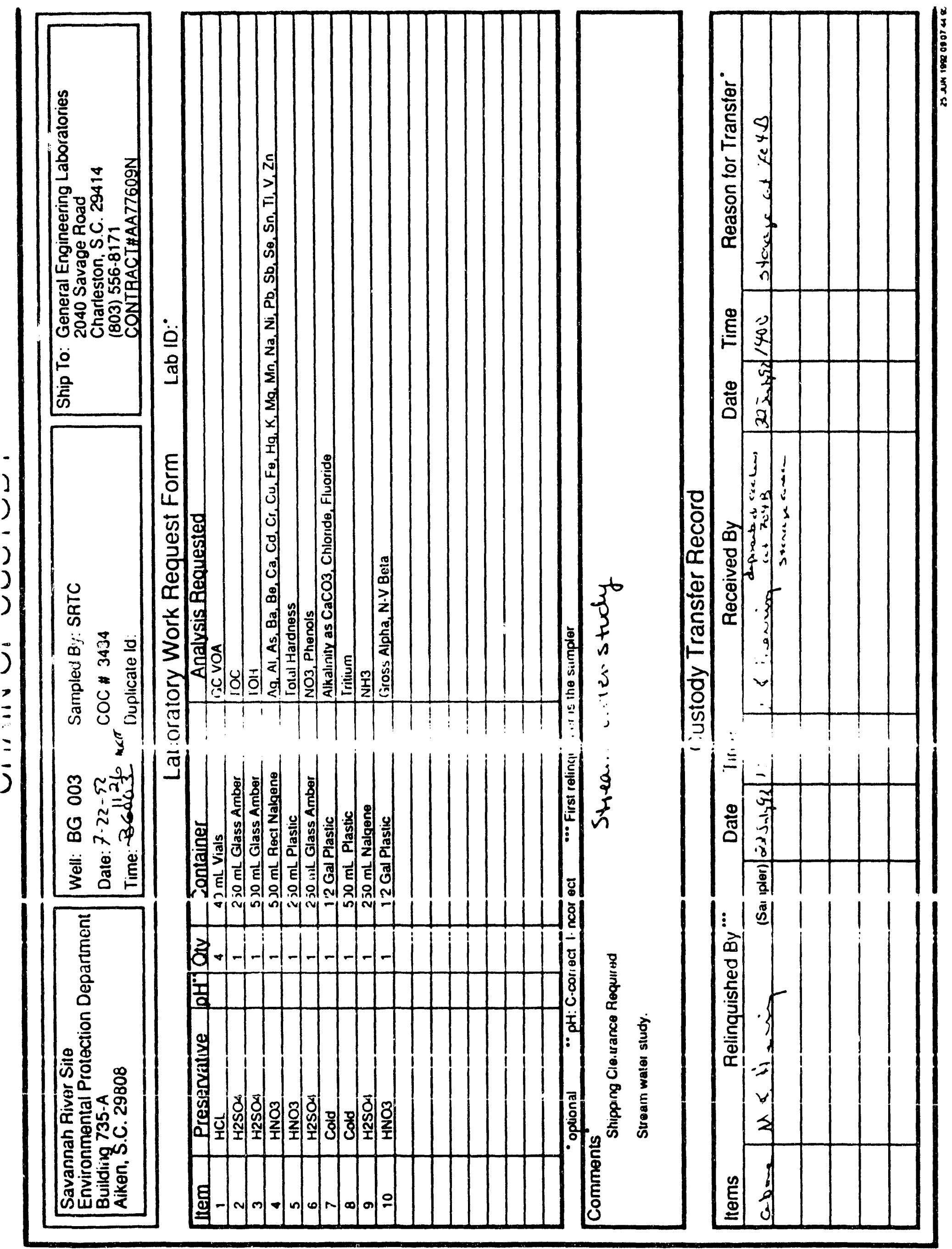




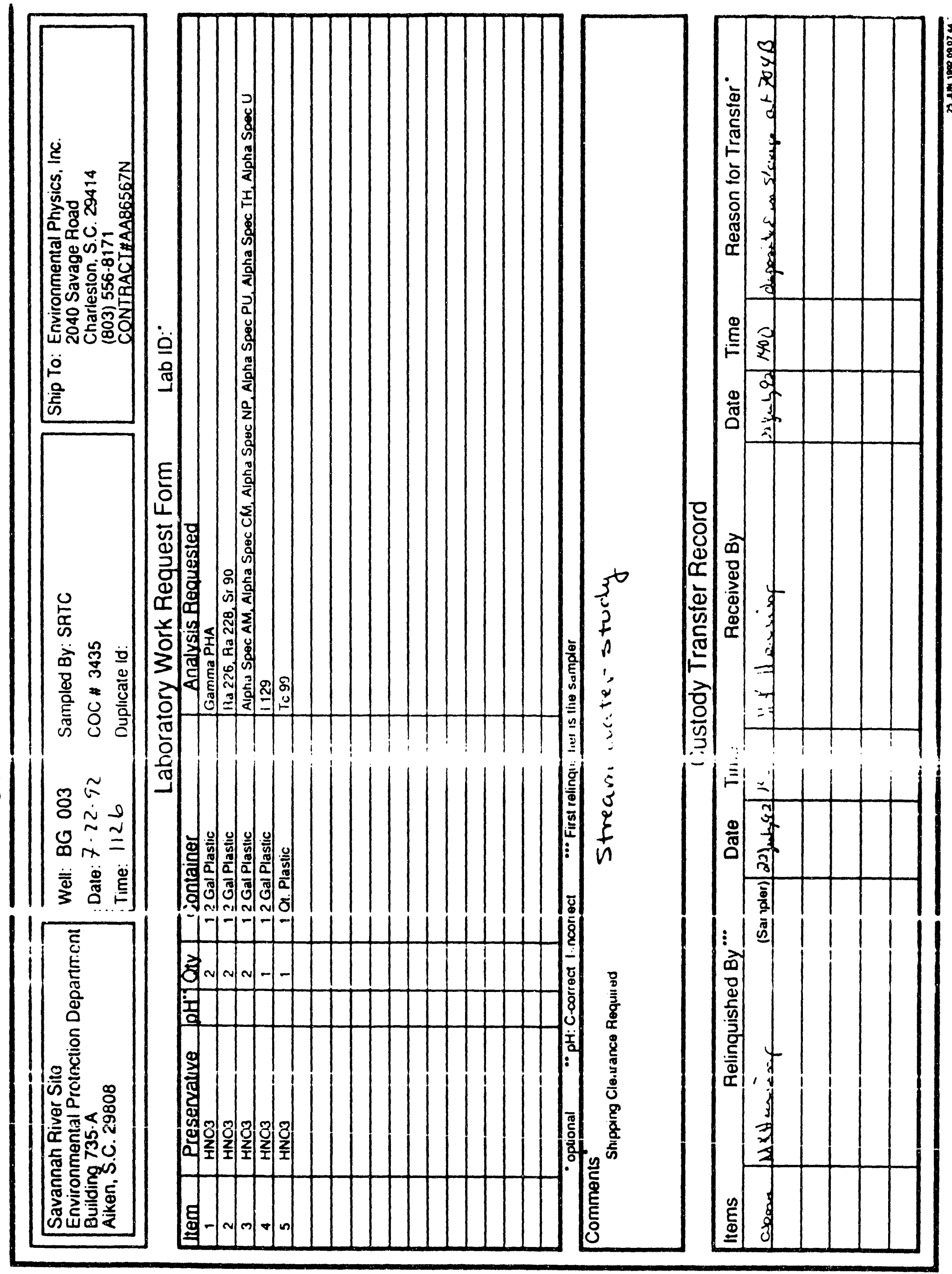




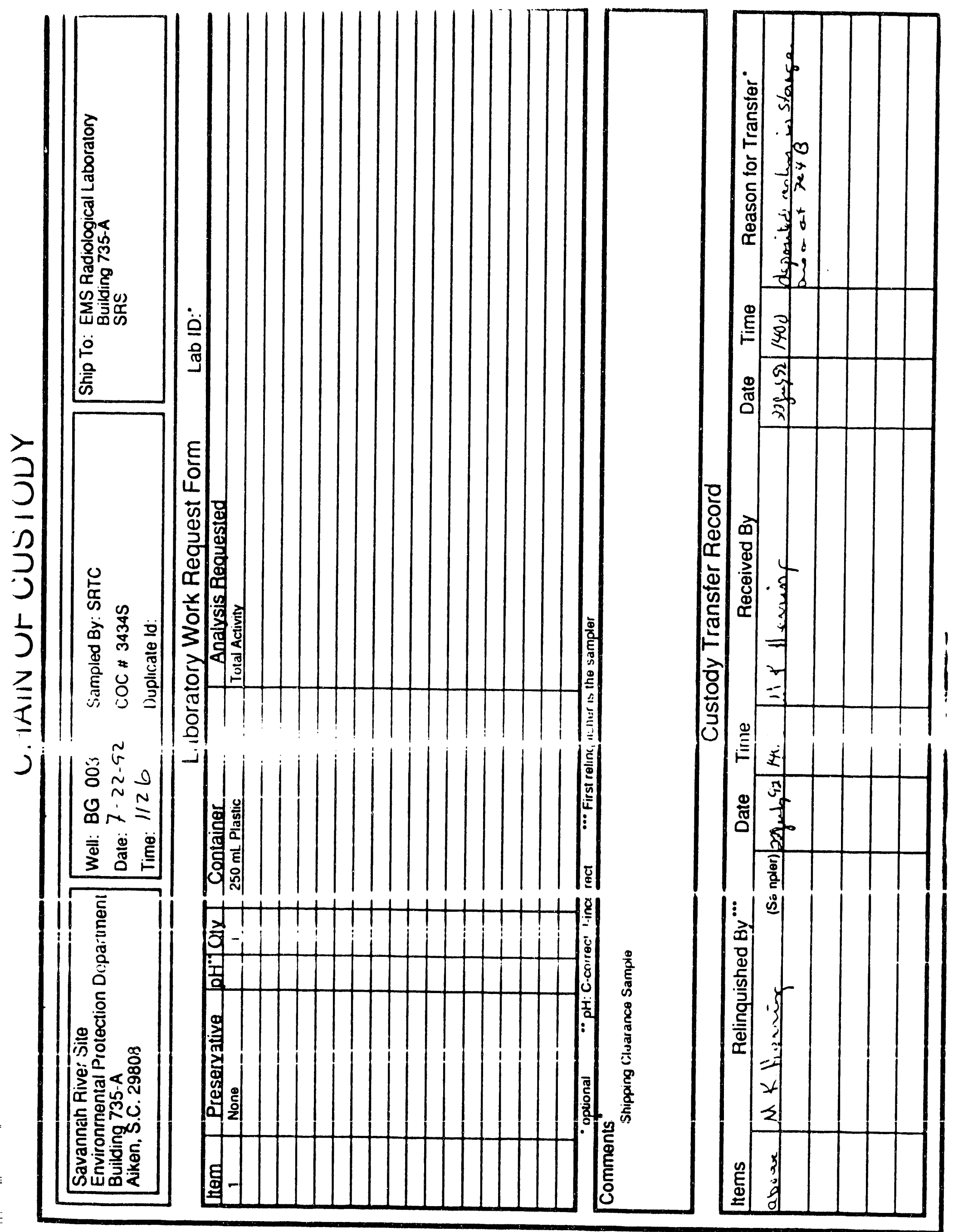




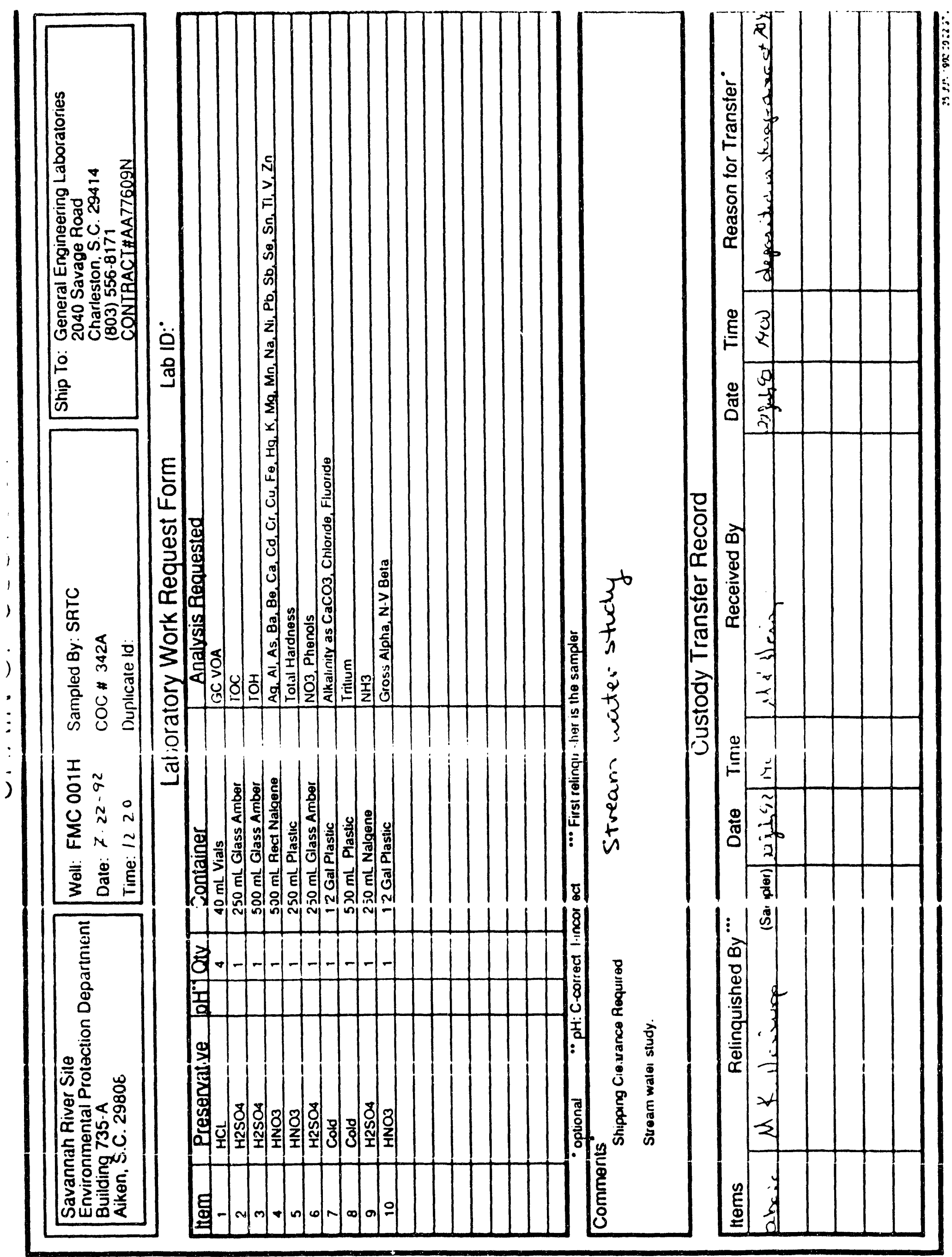




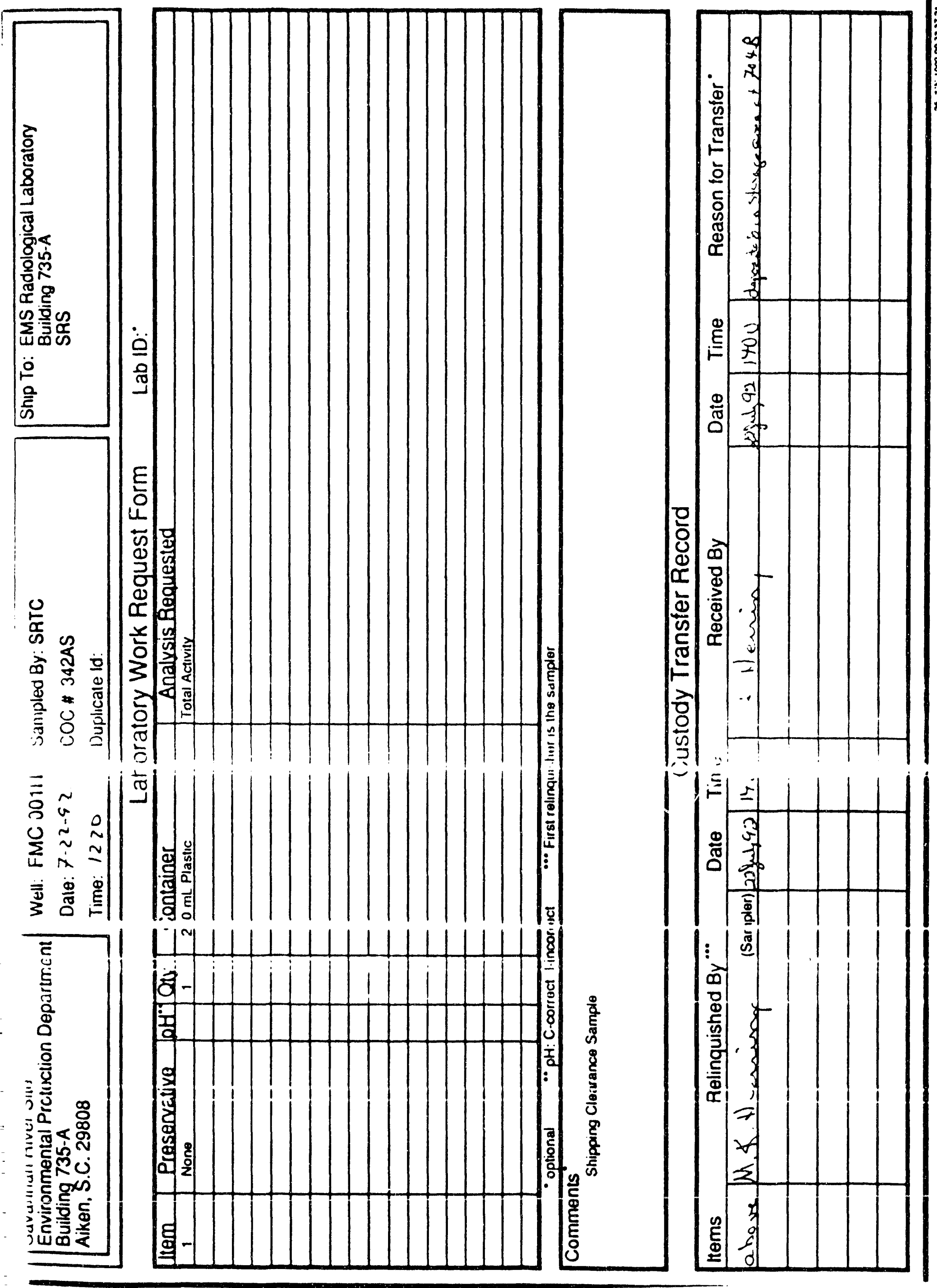




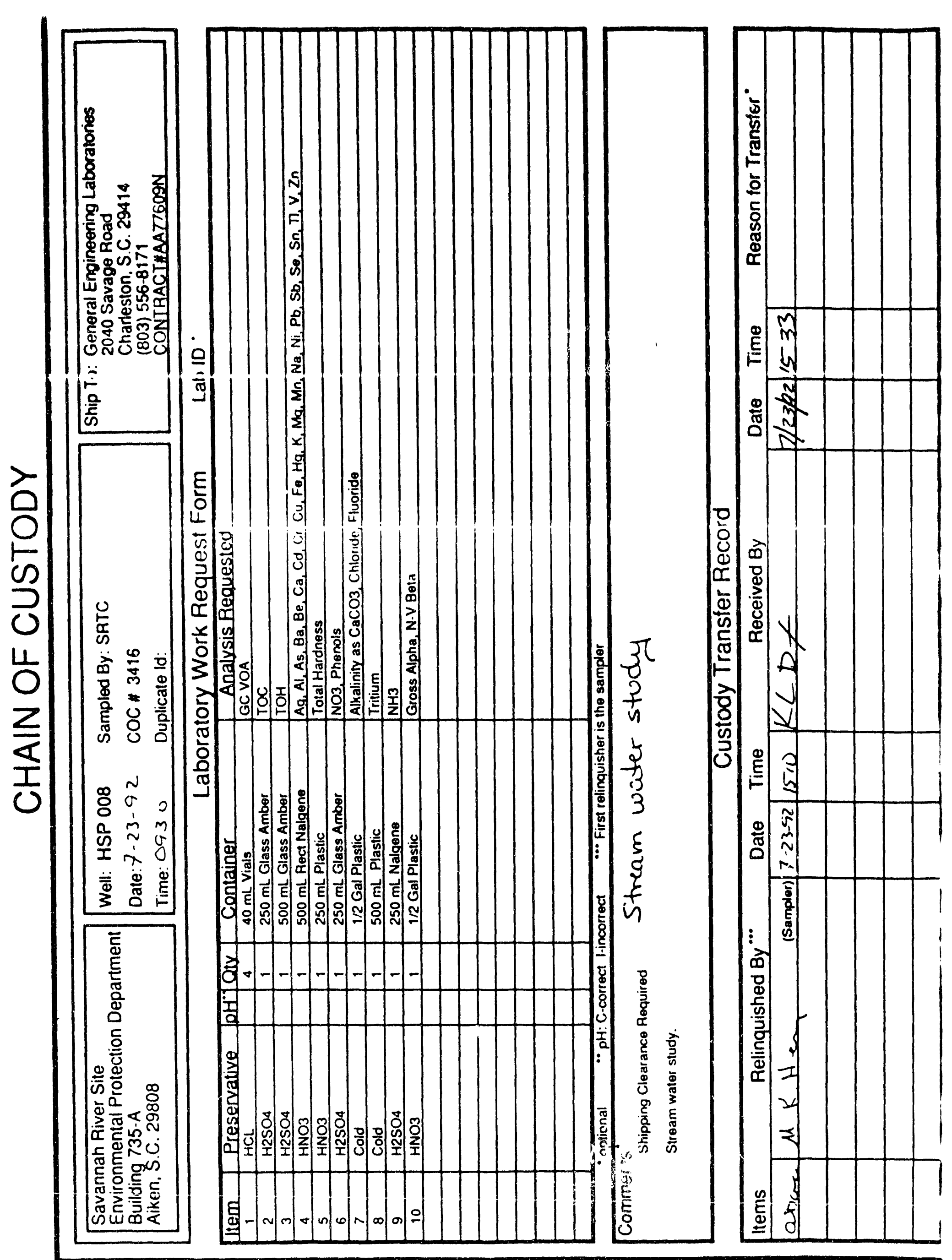




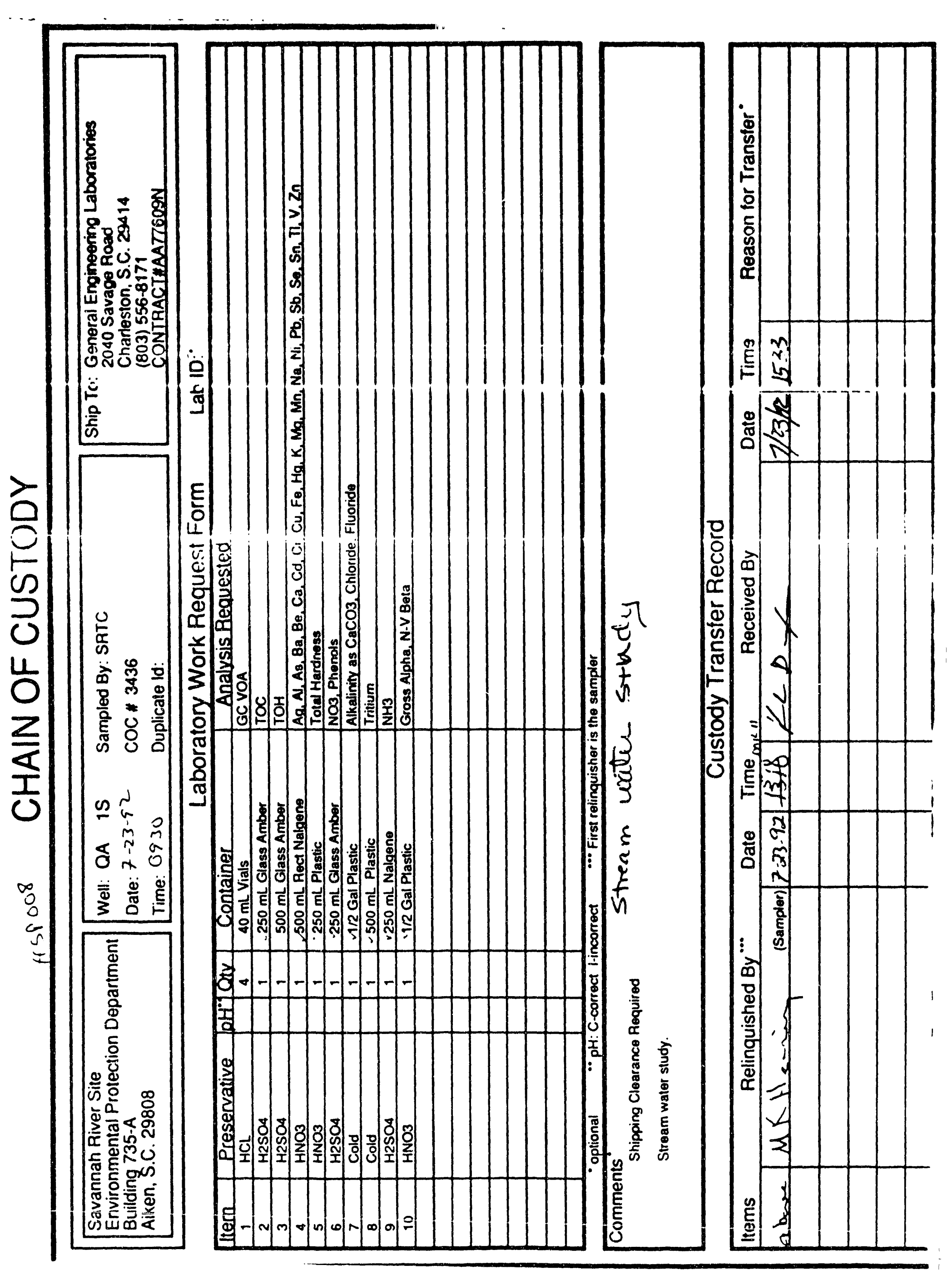




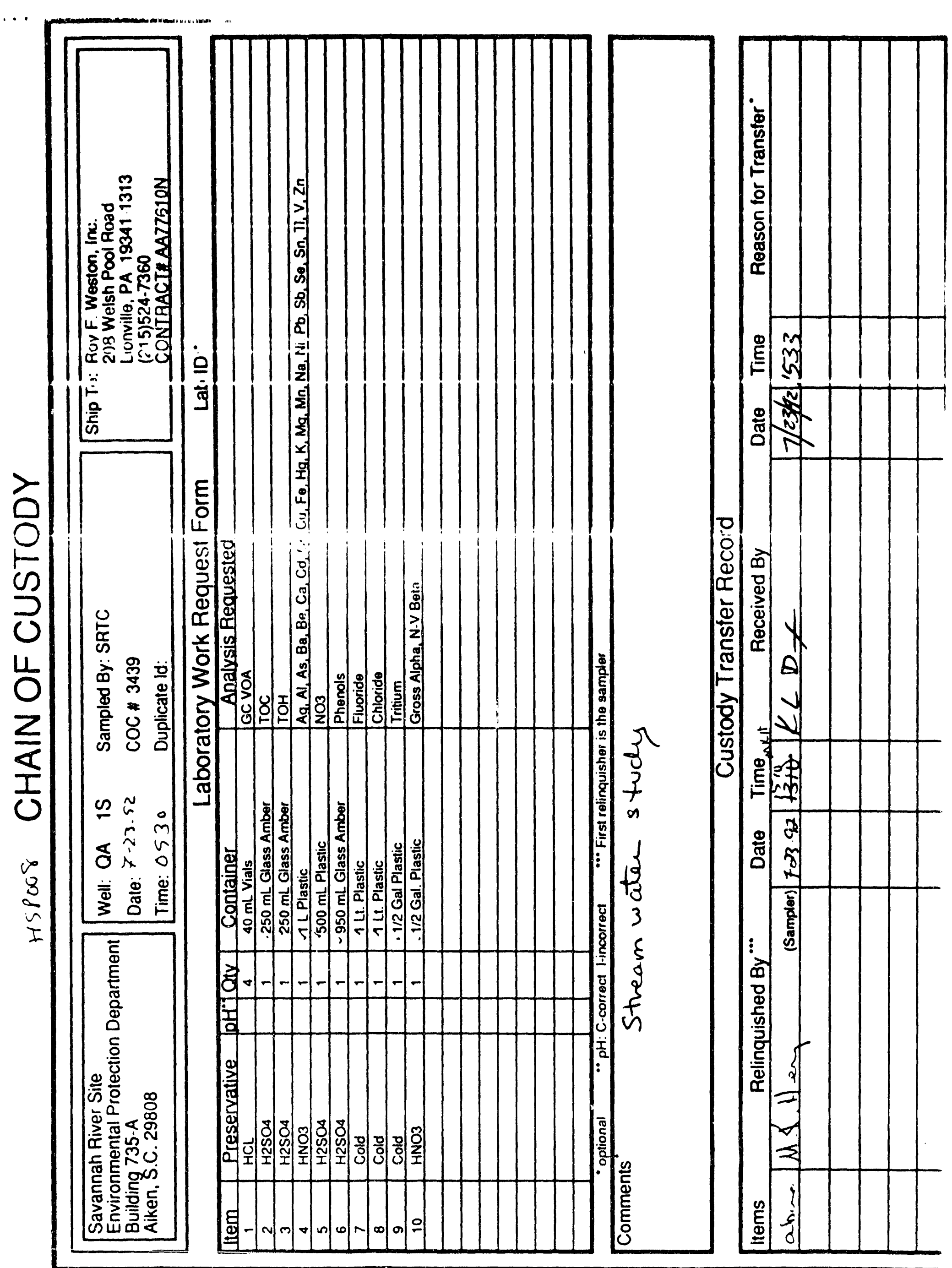




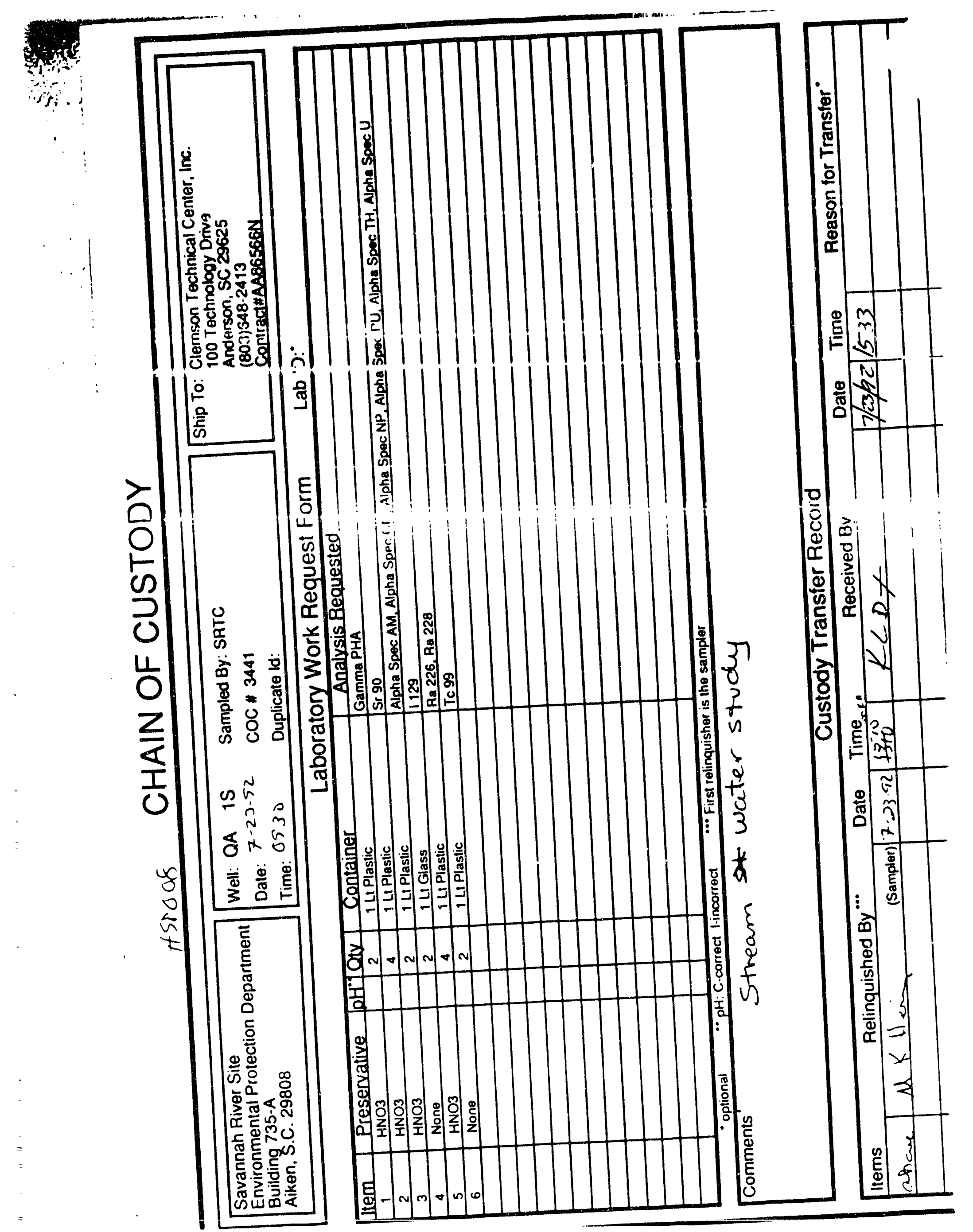




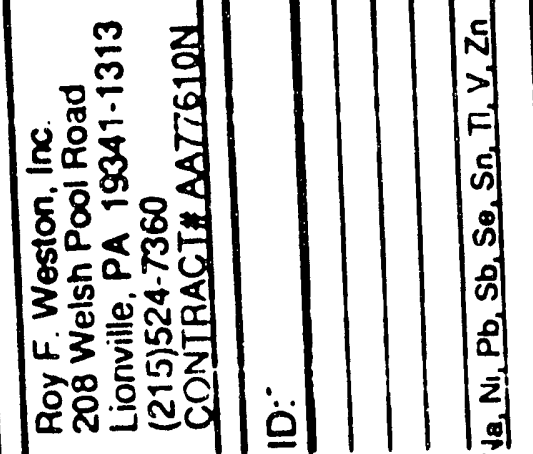

2
0
$\frac{0}{2}$
0

O

z

종

\%

年

豙总道

a

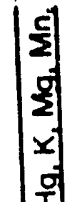

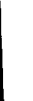
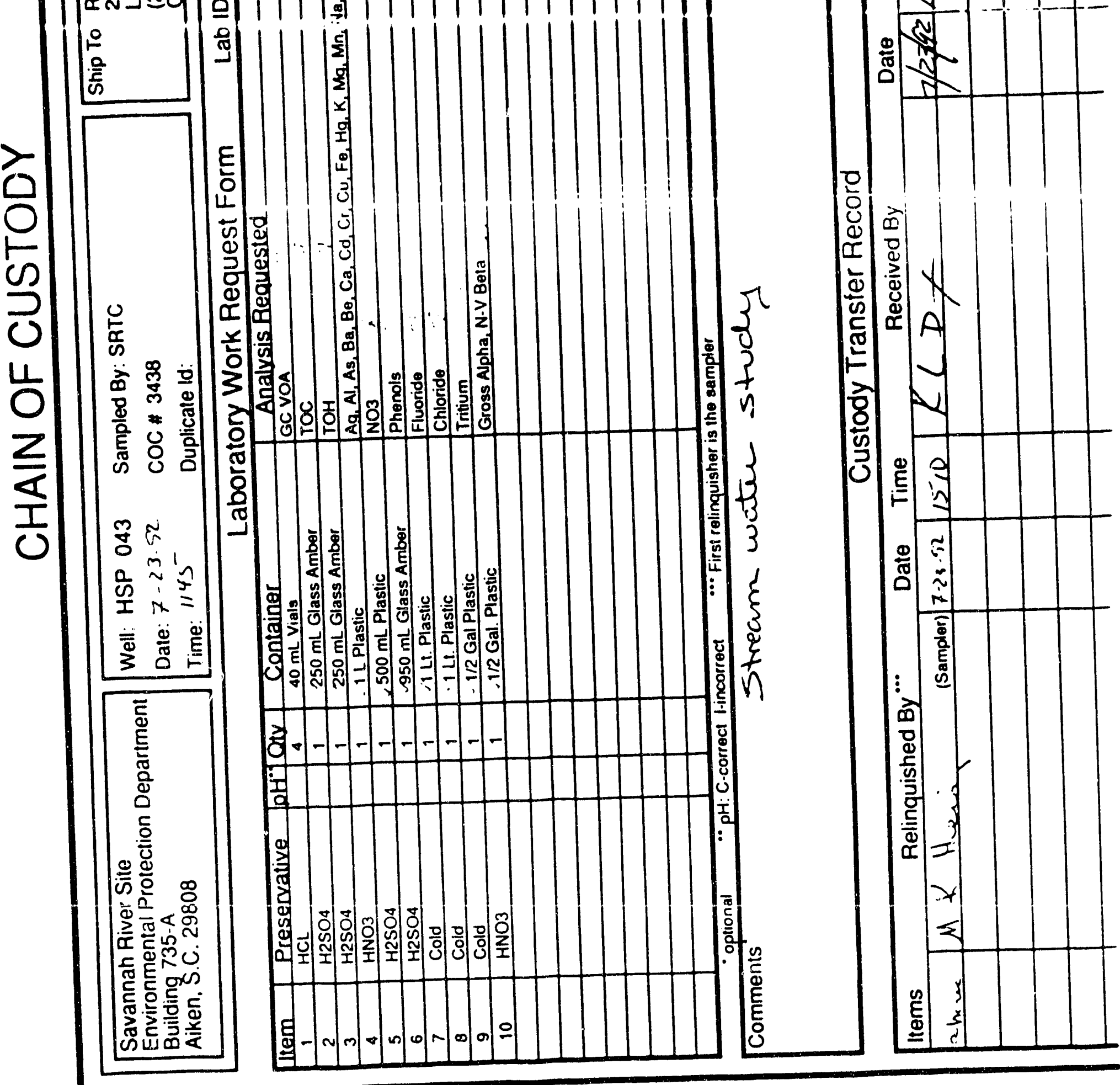


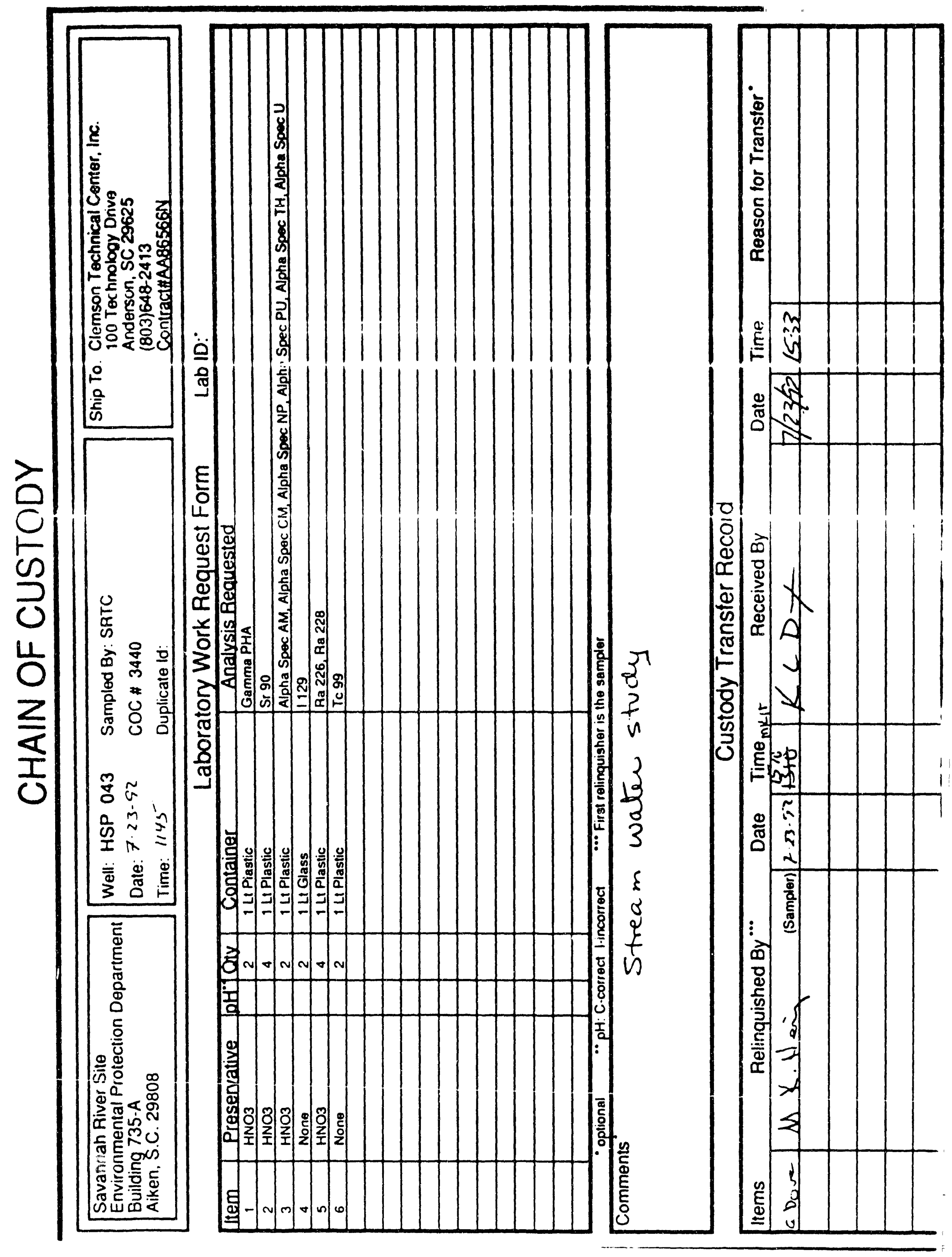




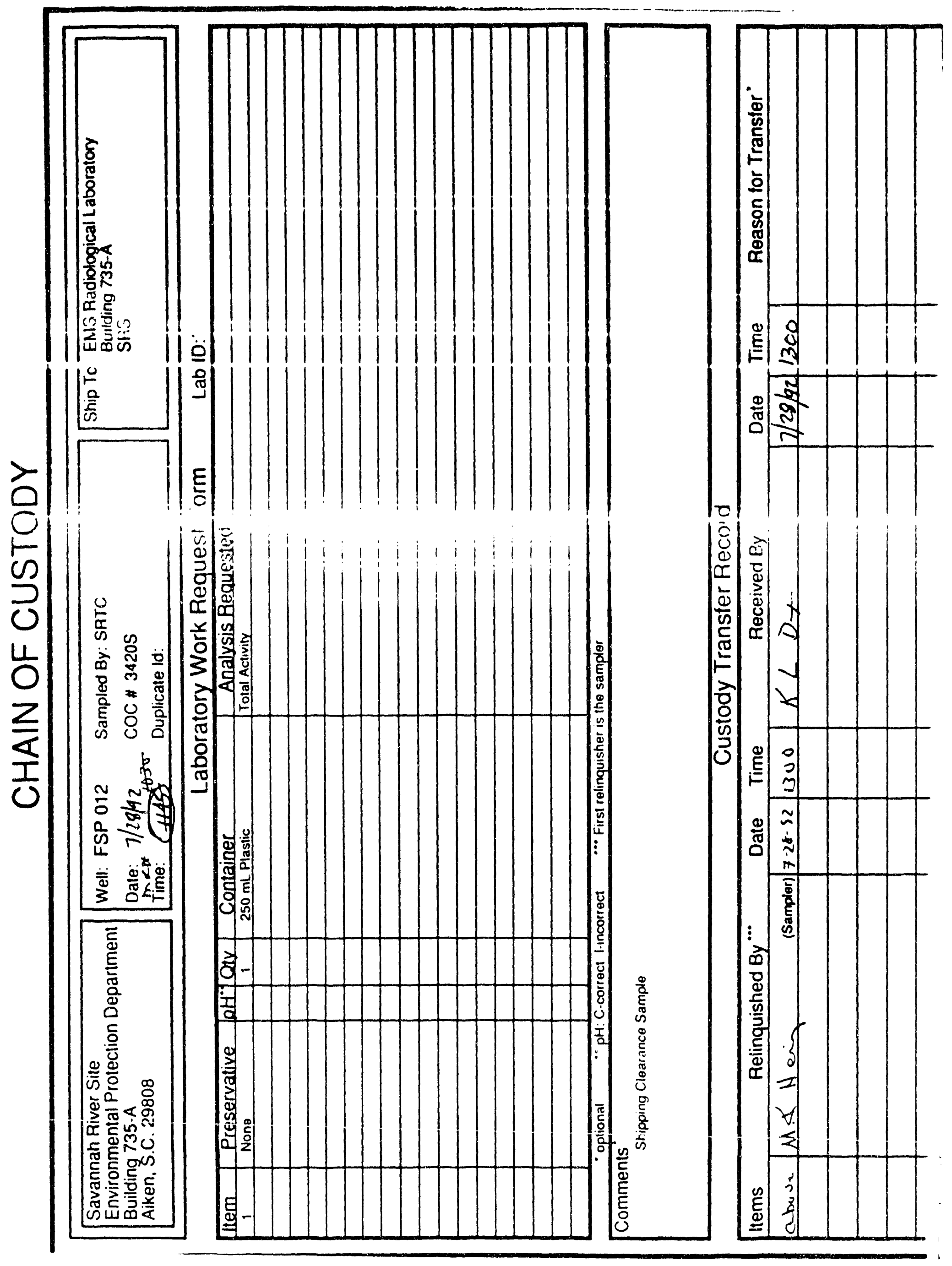




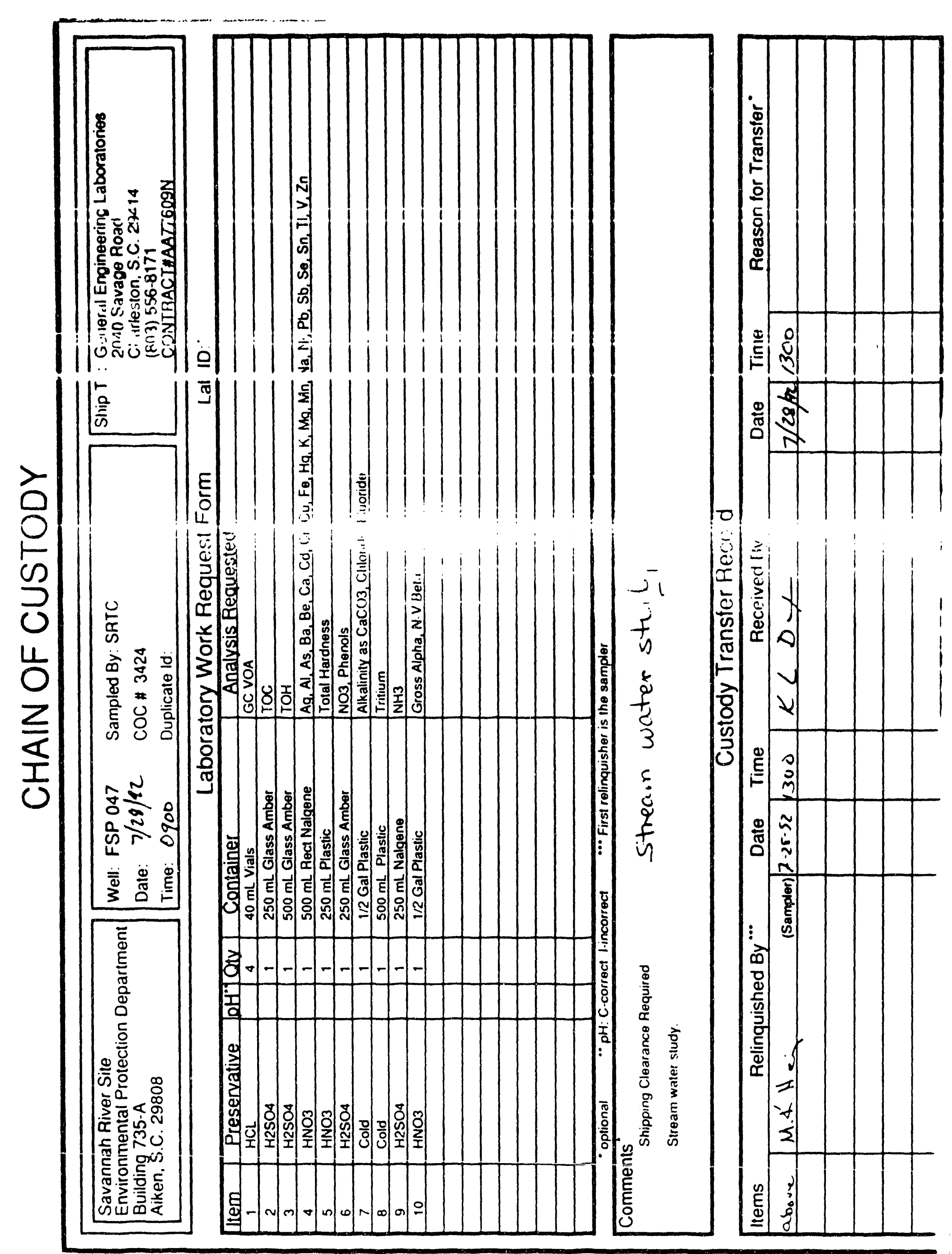




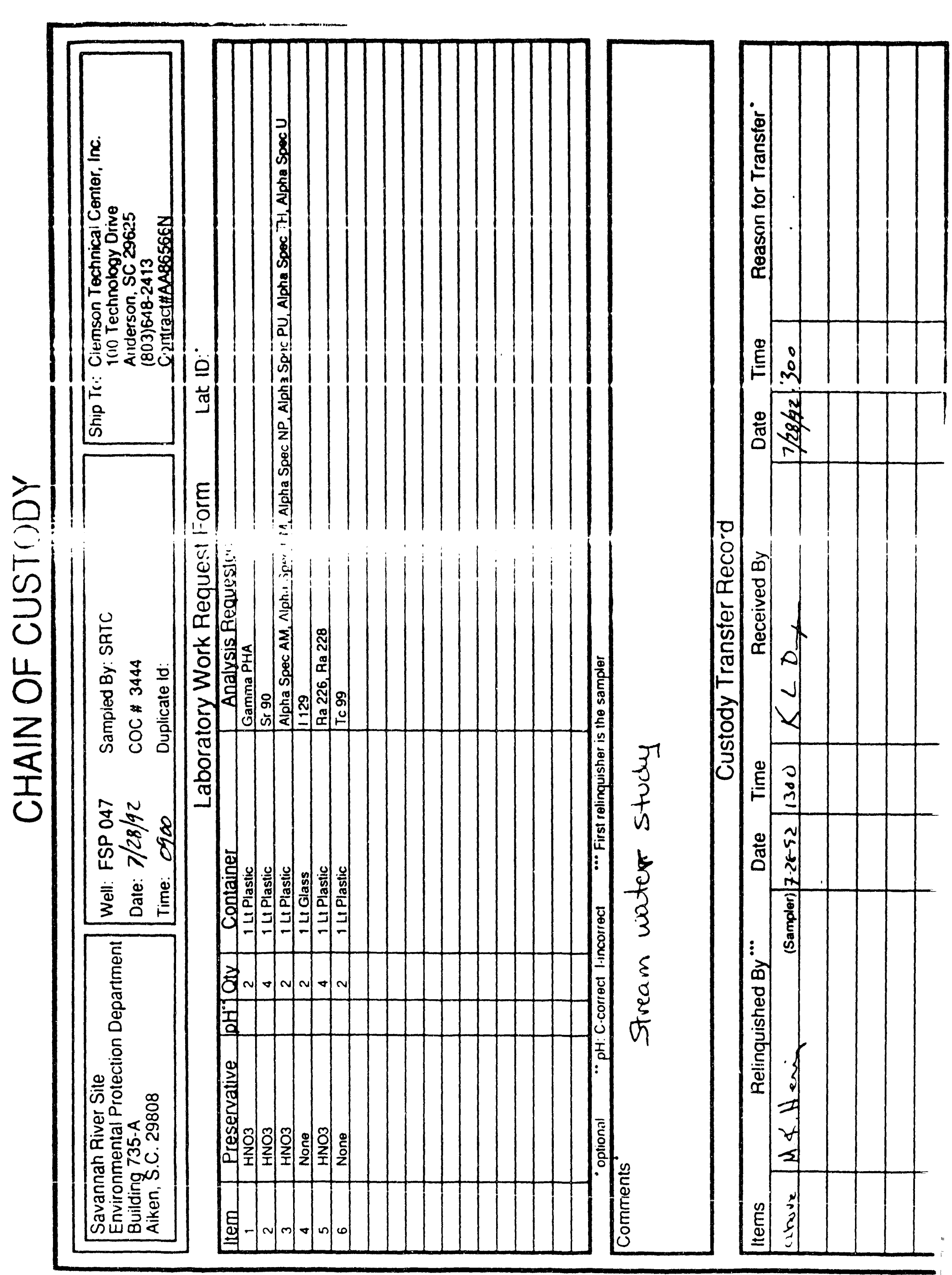




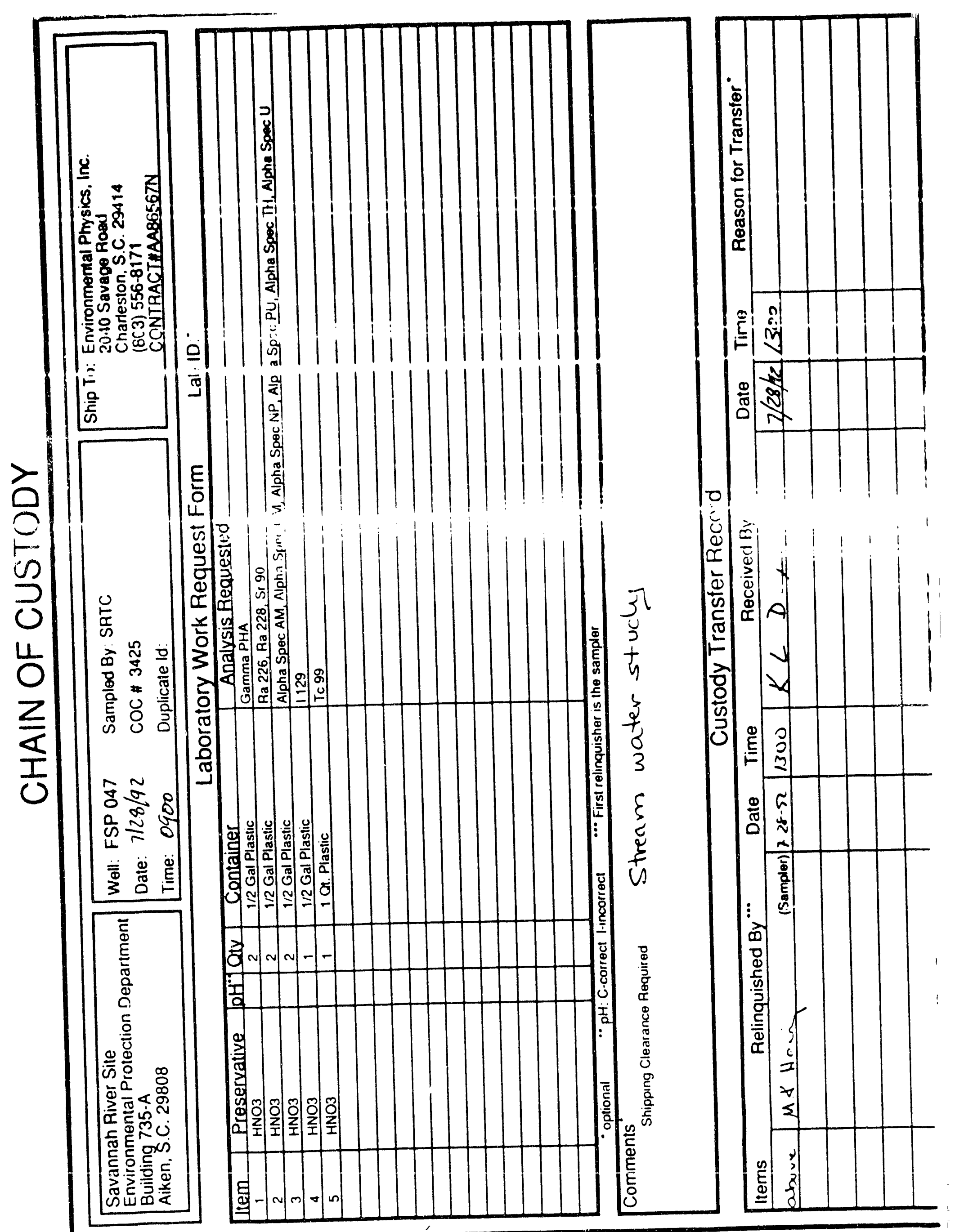




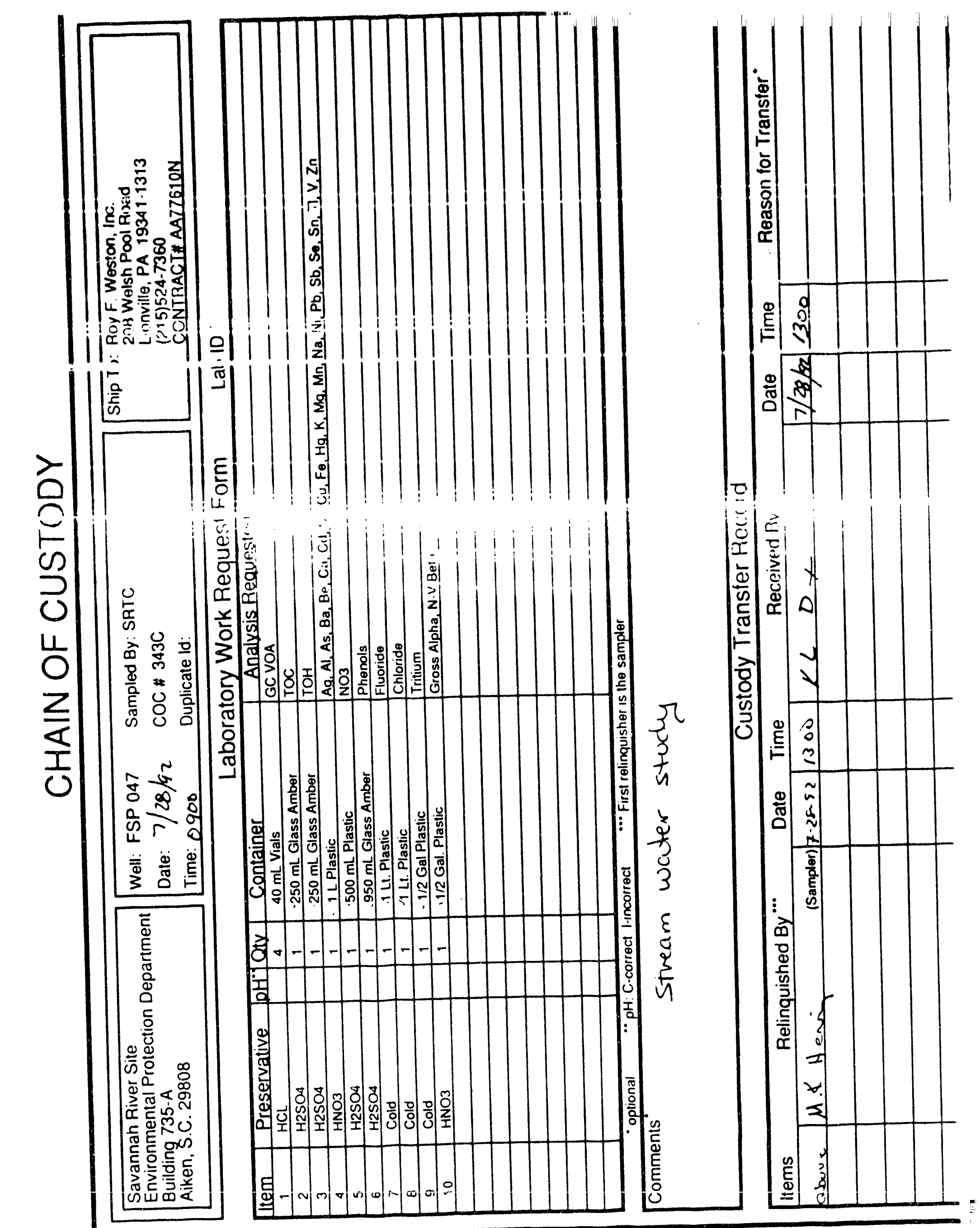




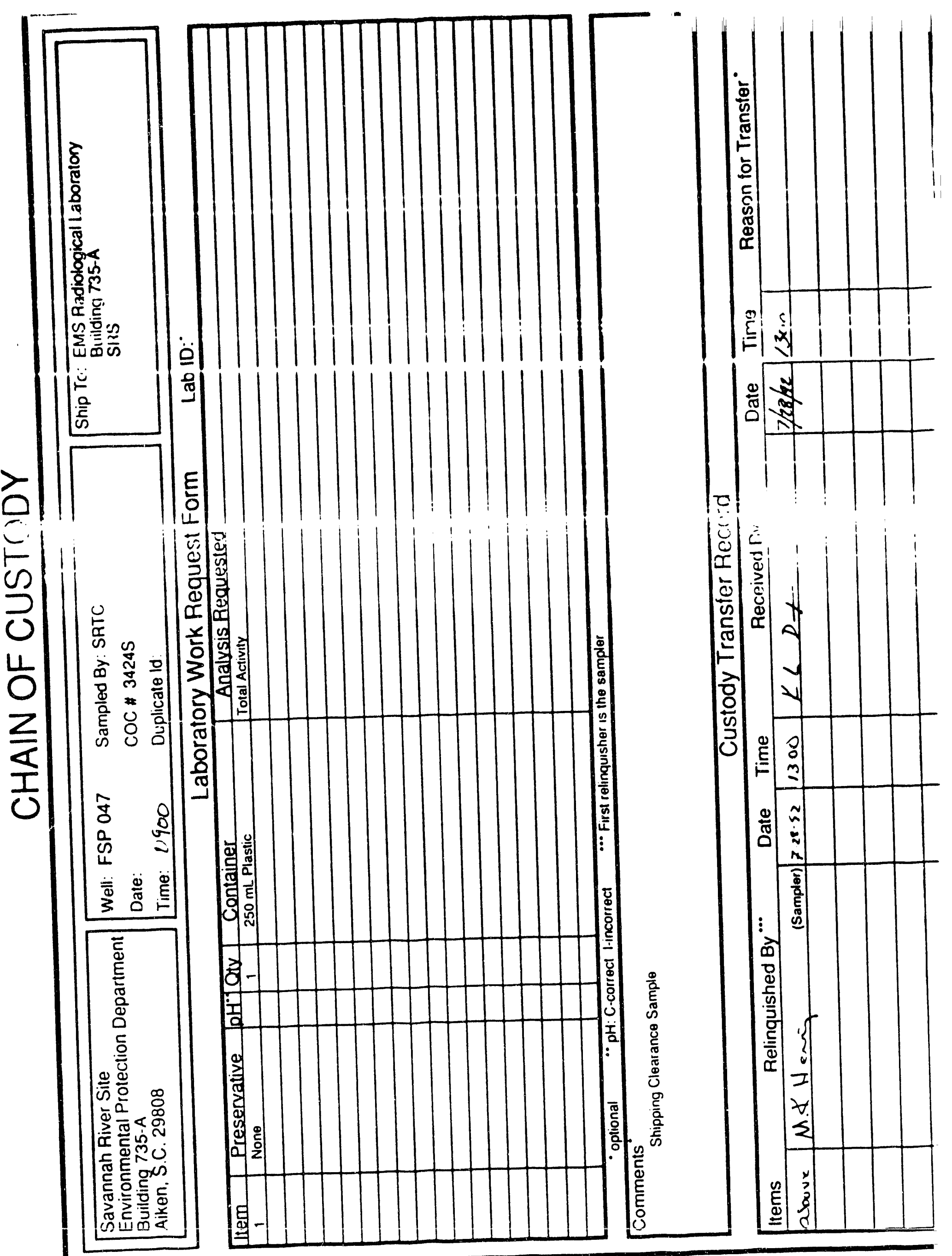




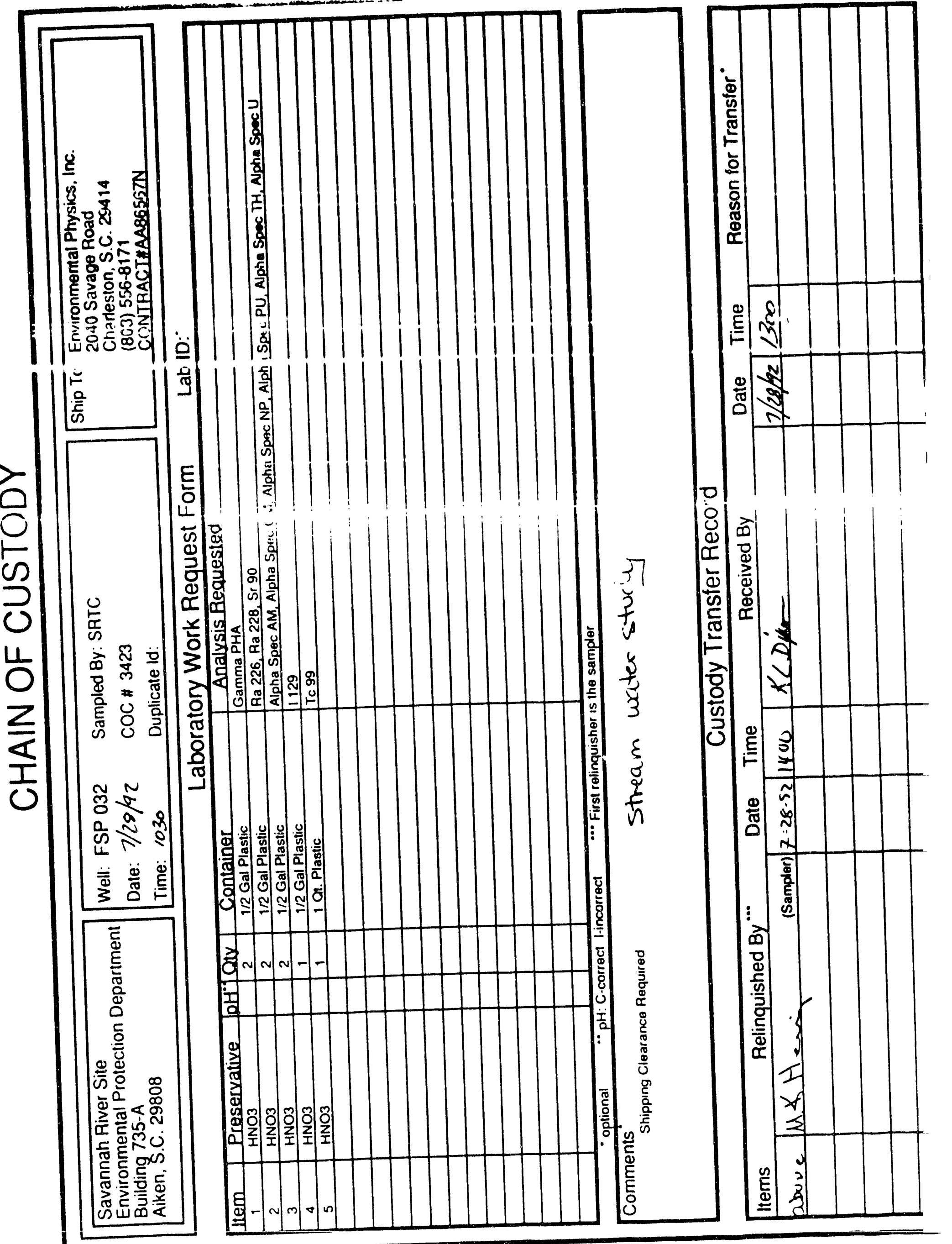




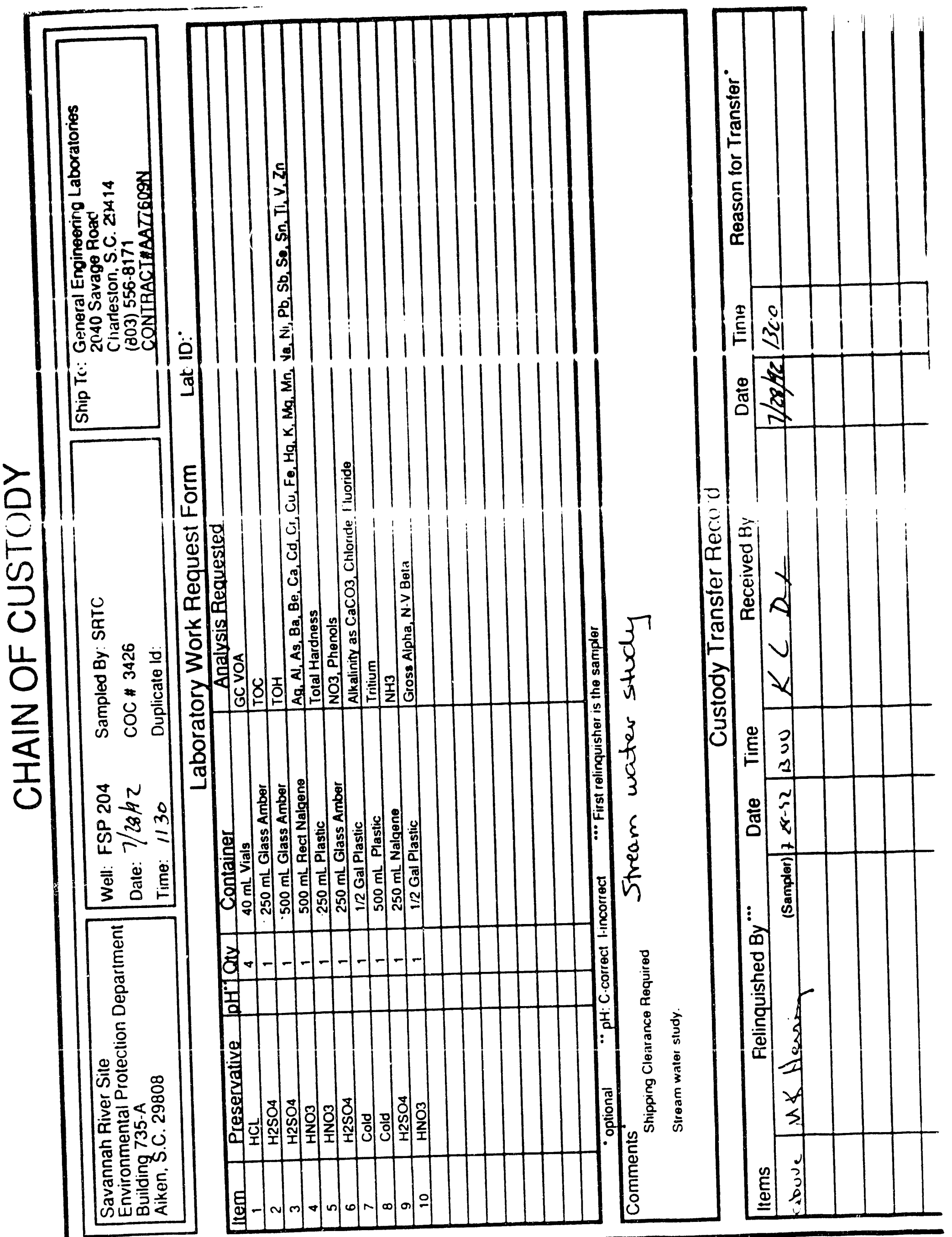




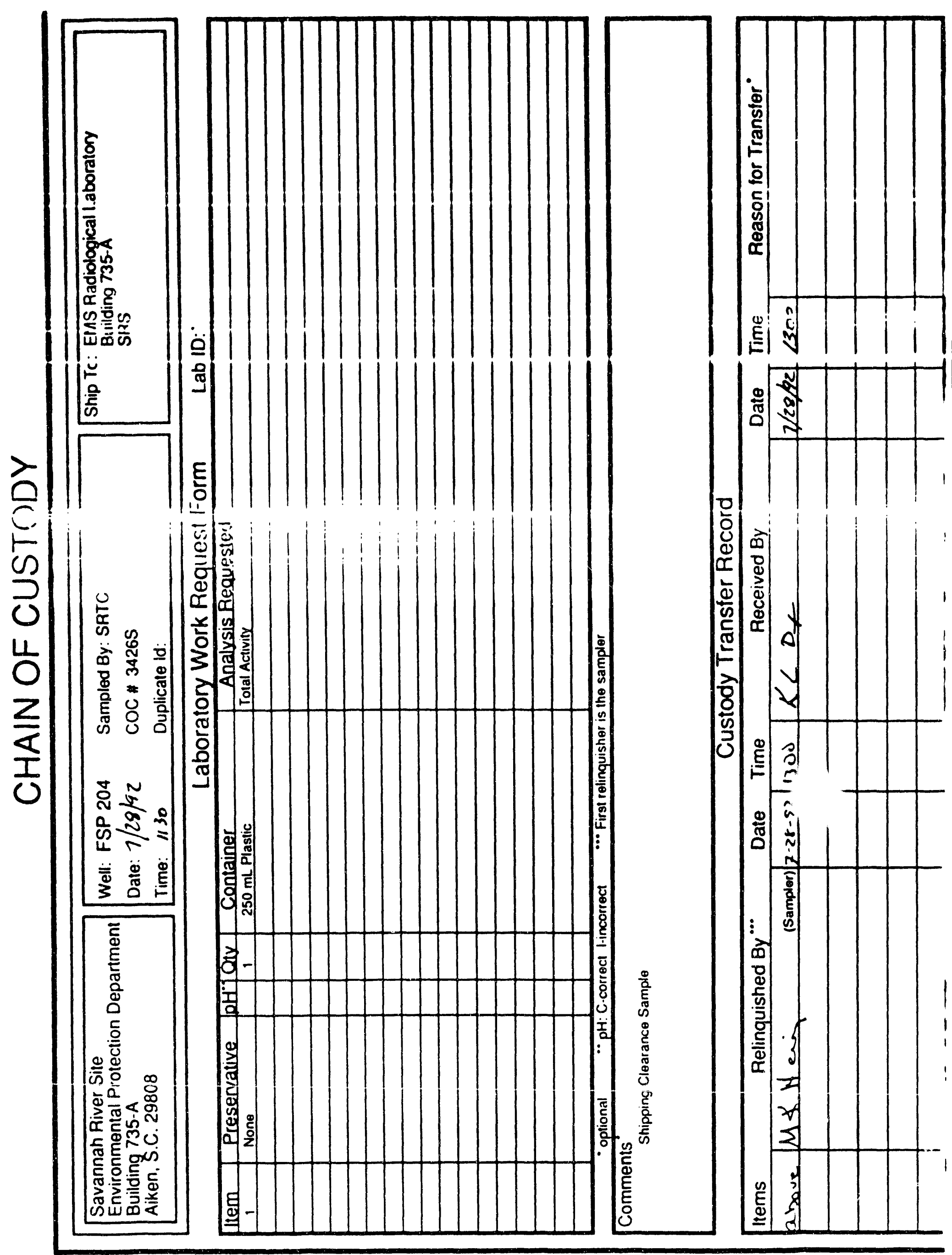




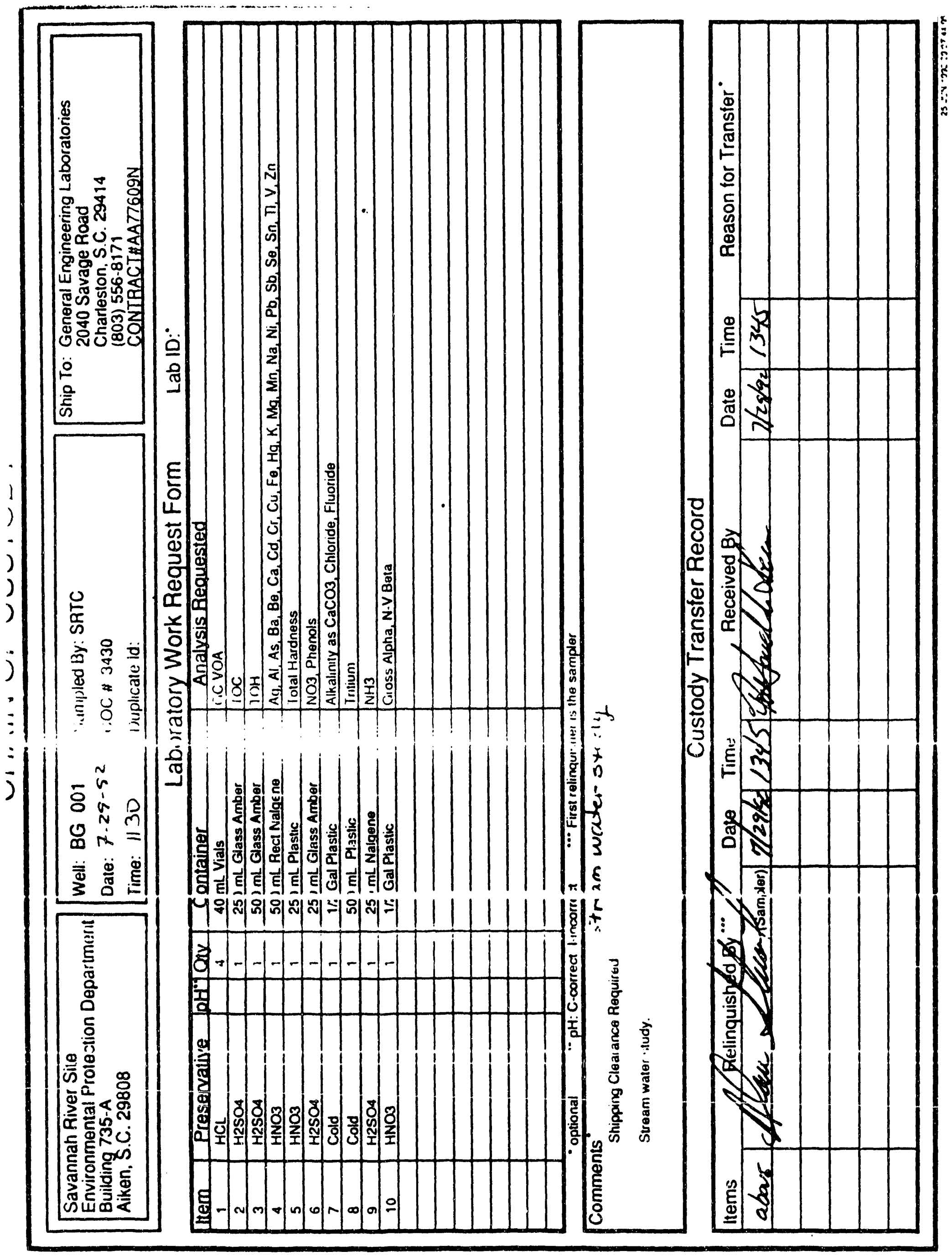




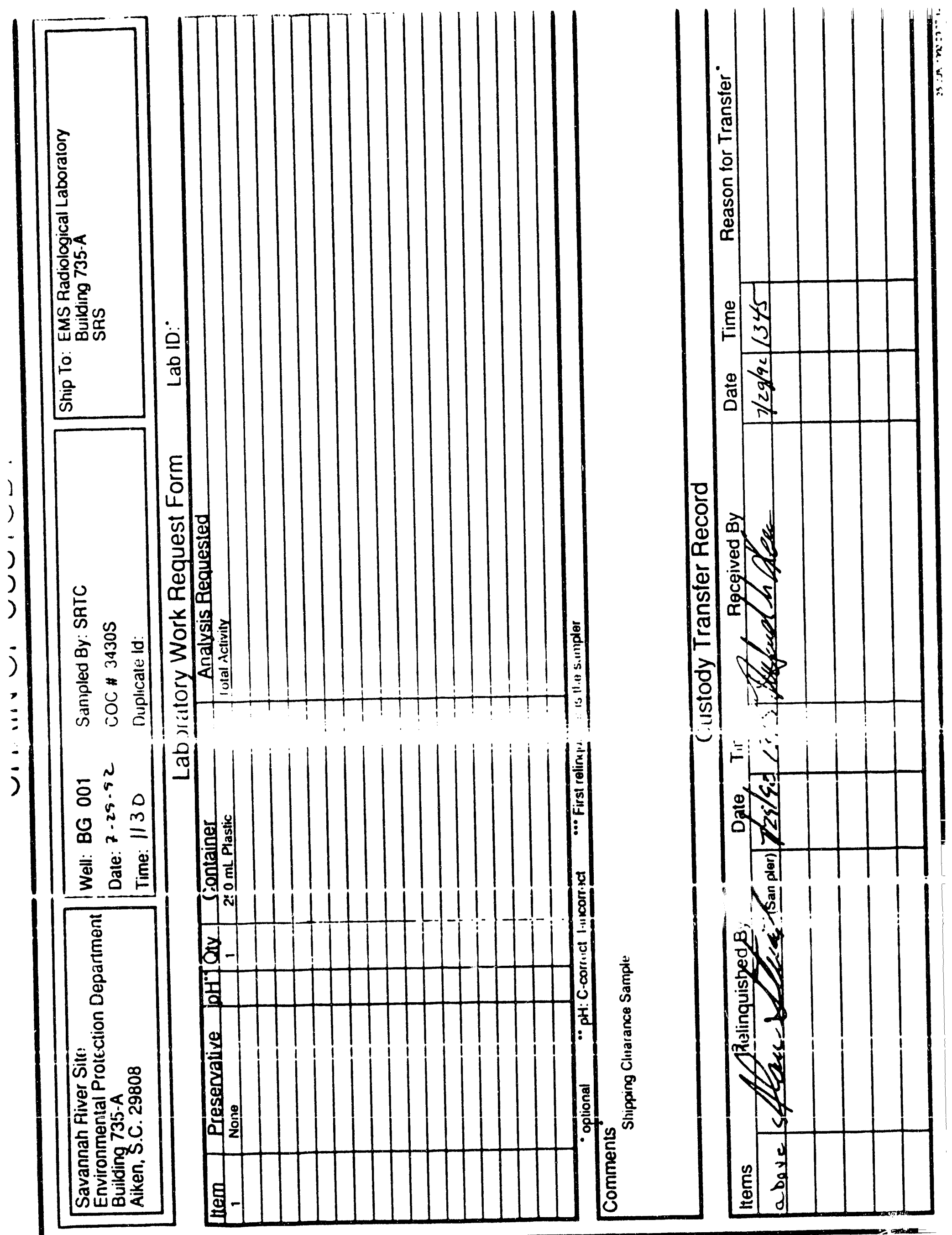




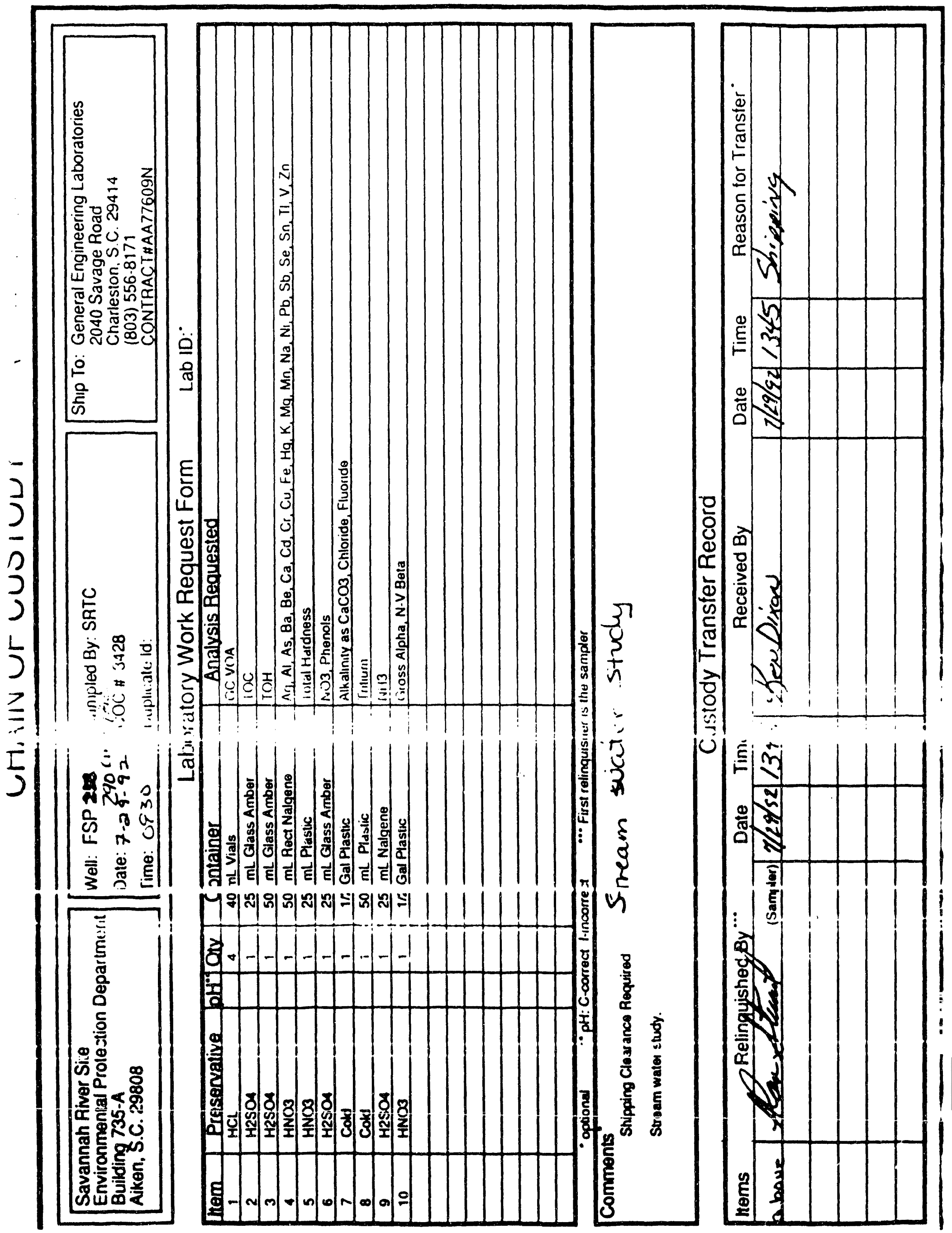




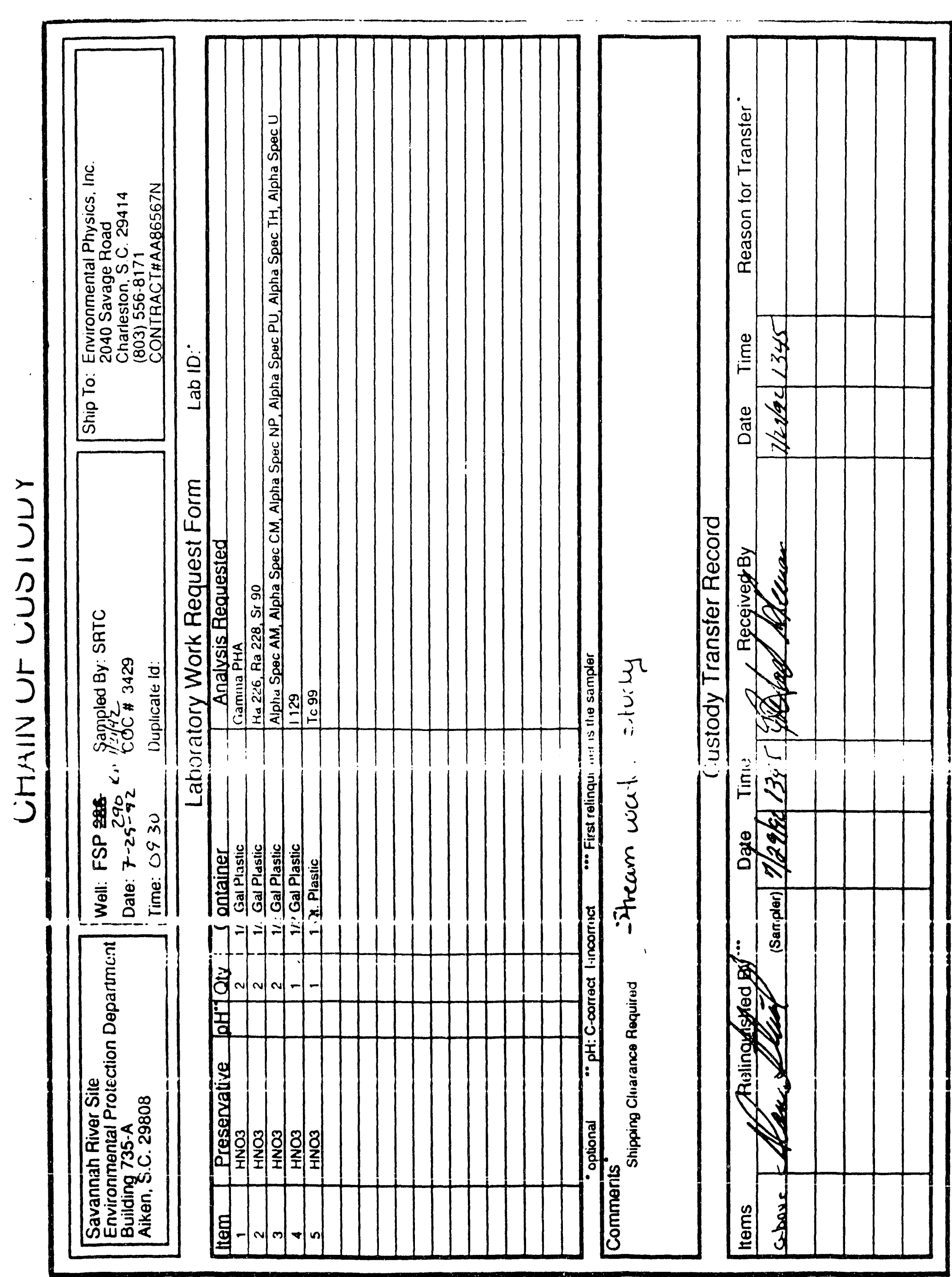




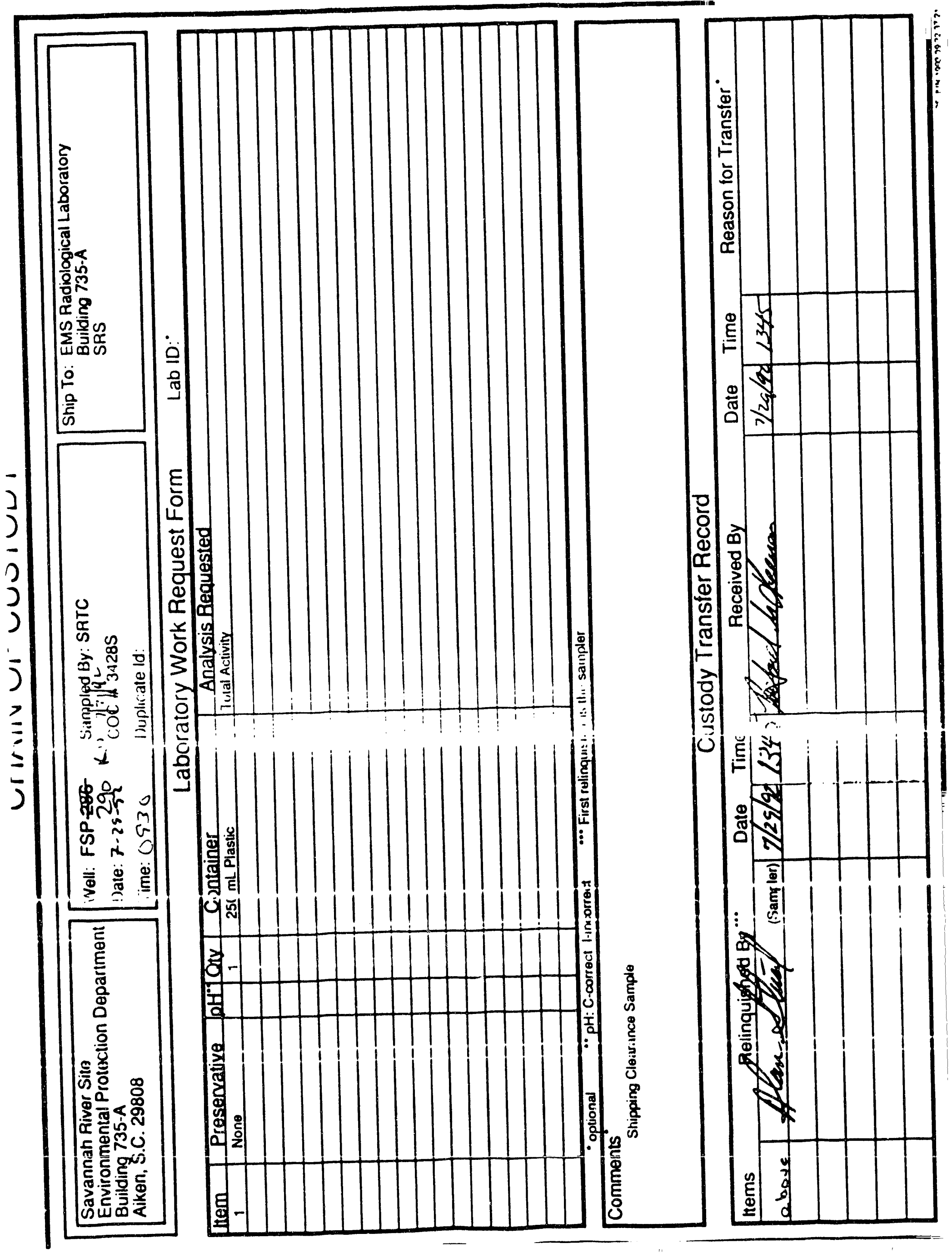




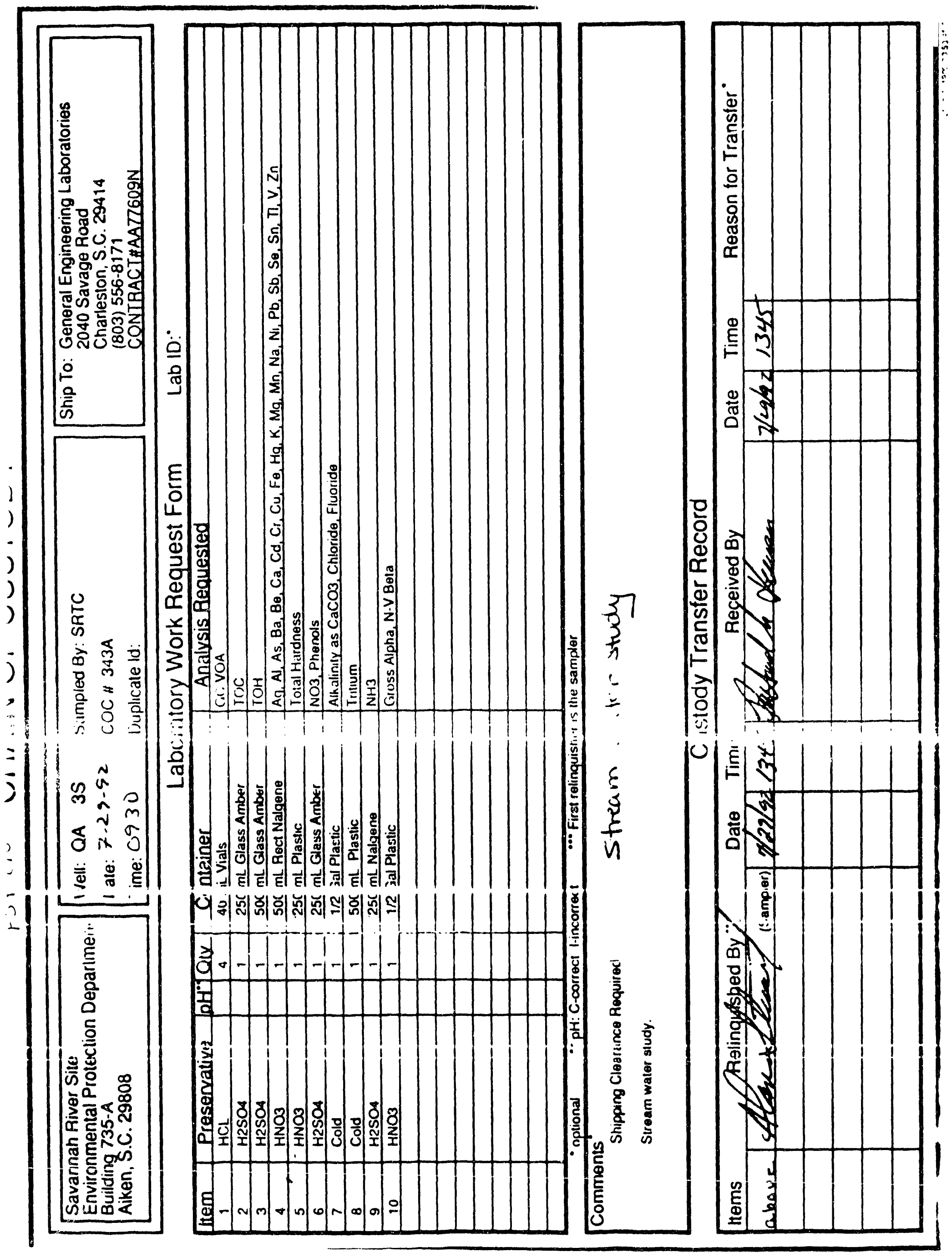




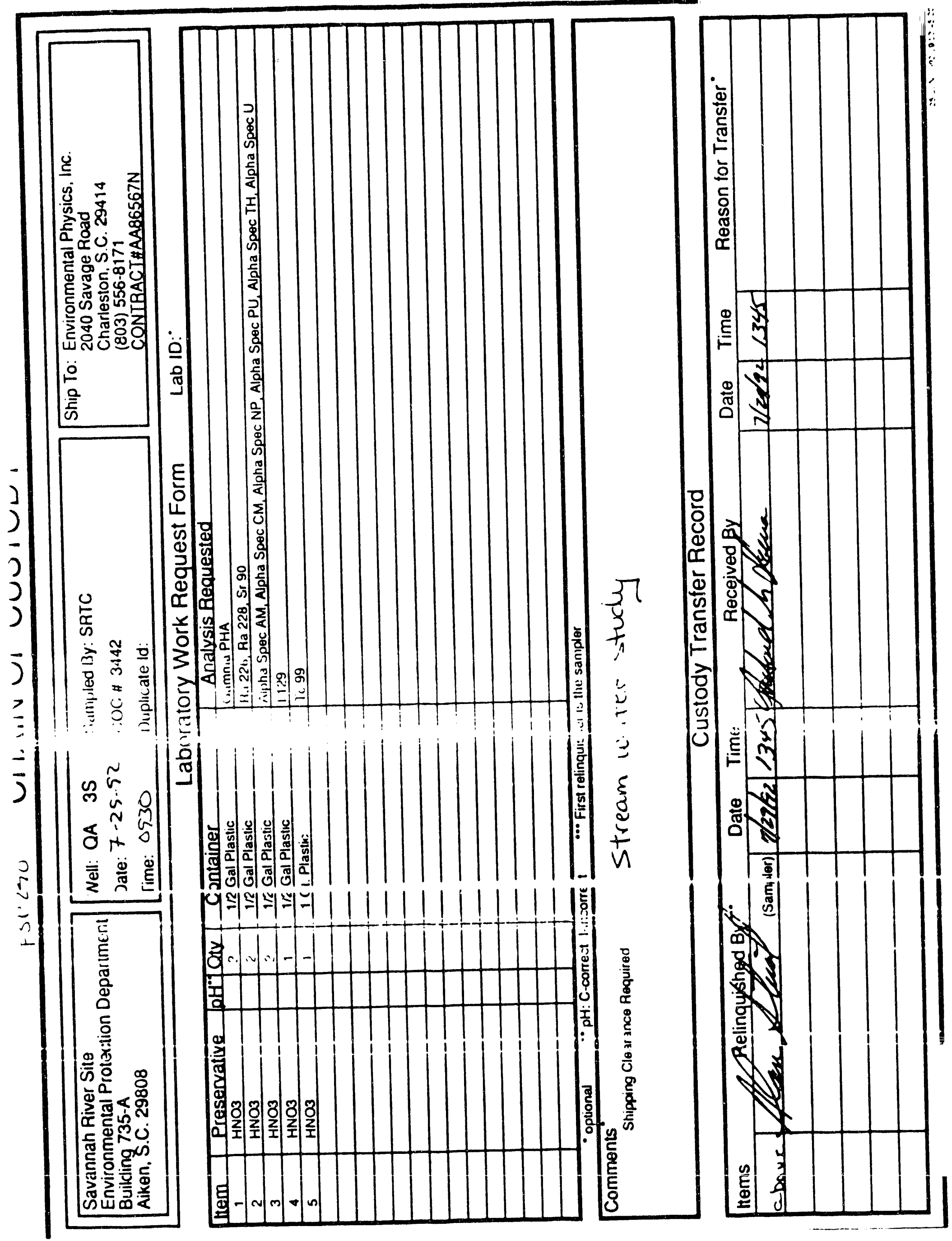




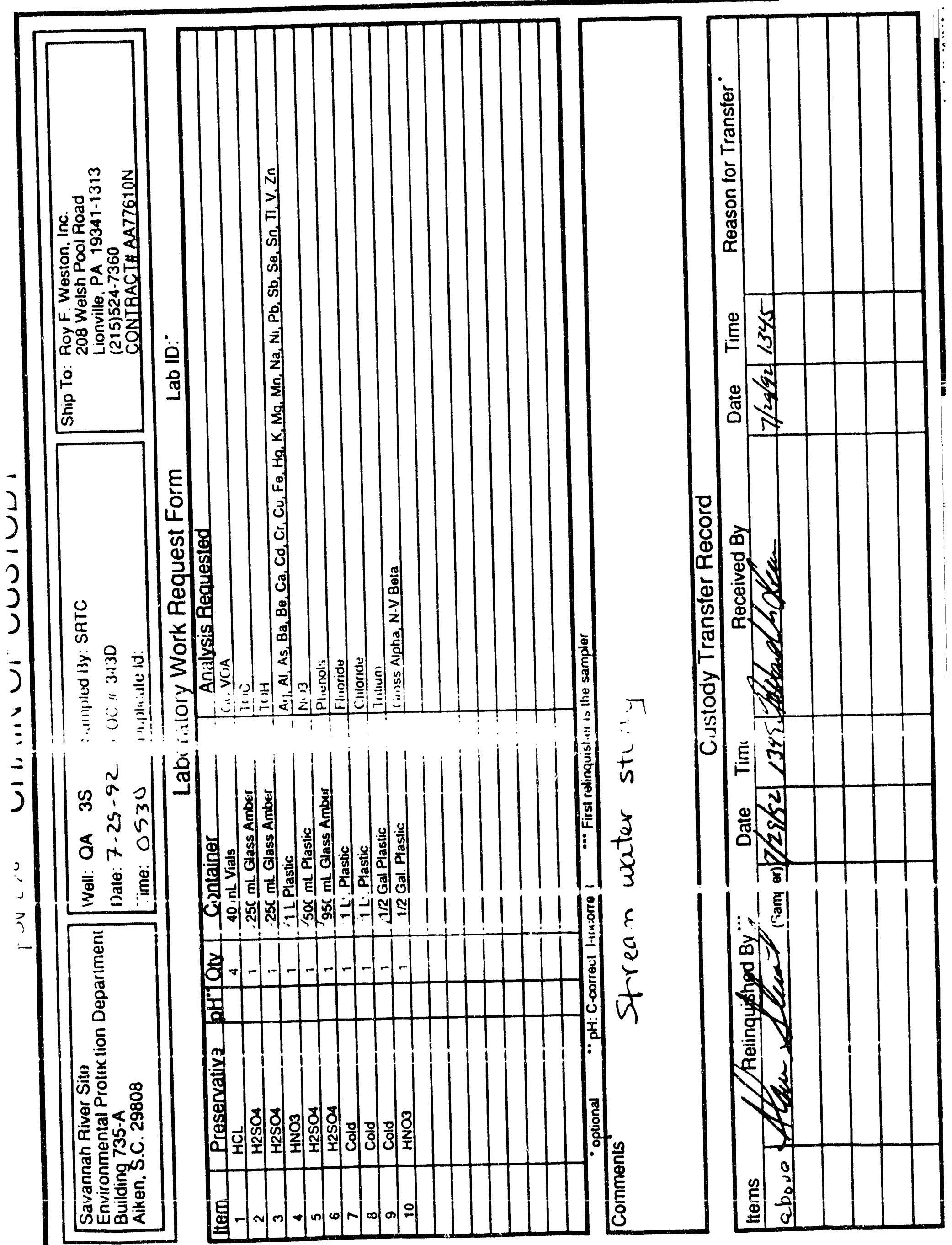




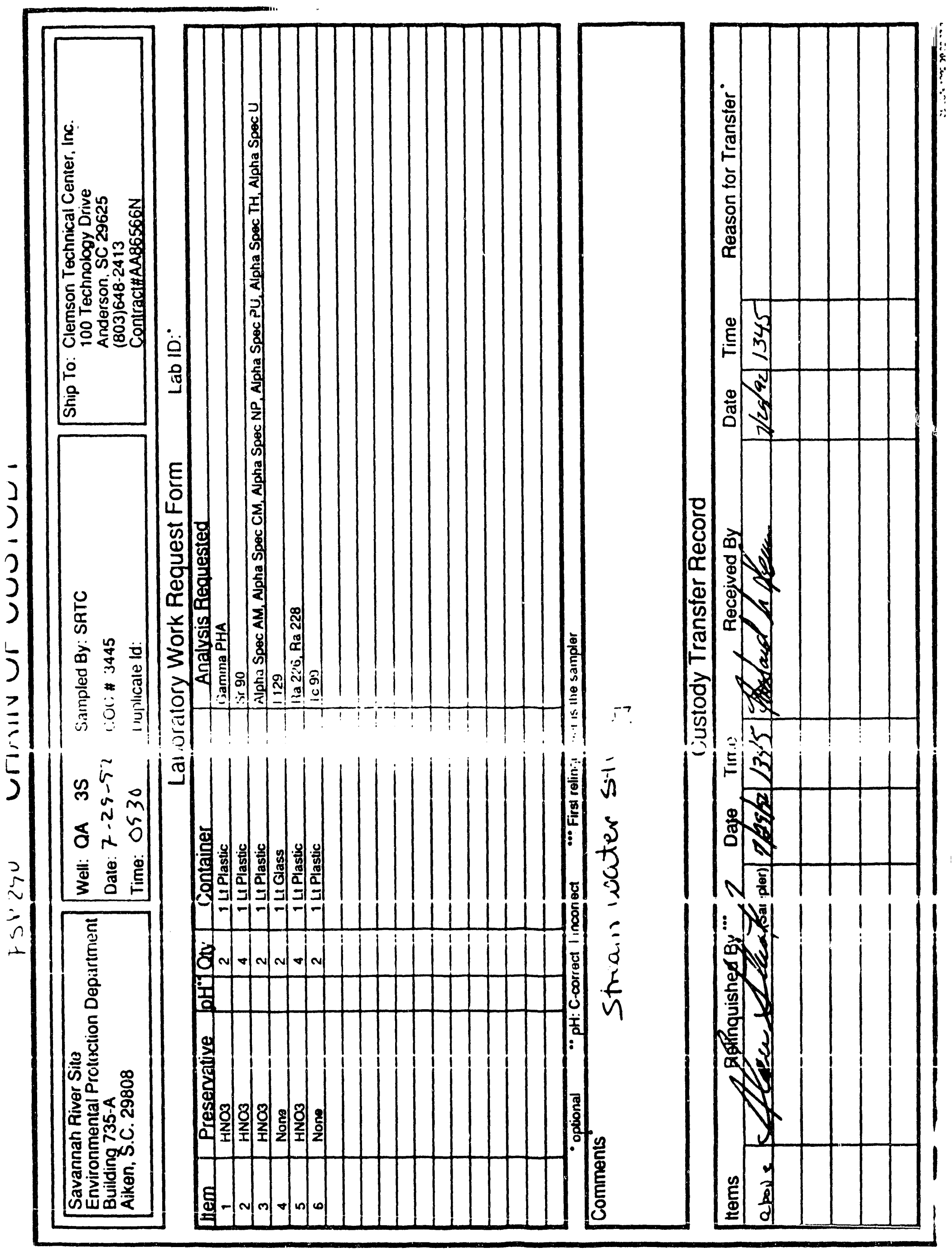




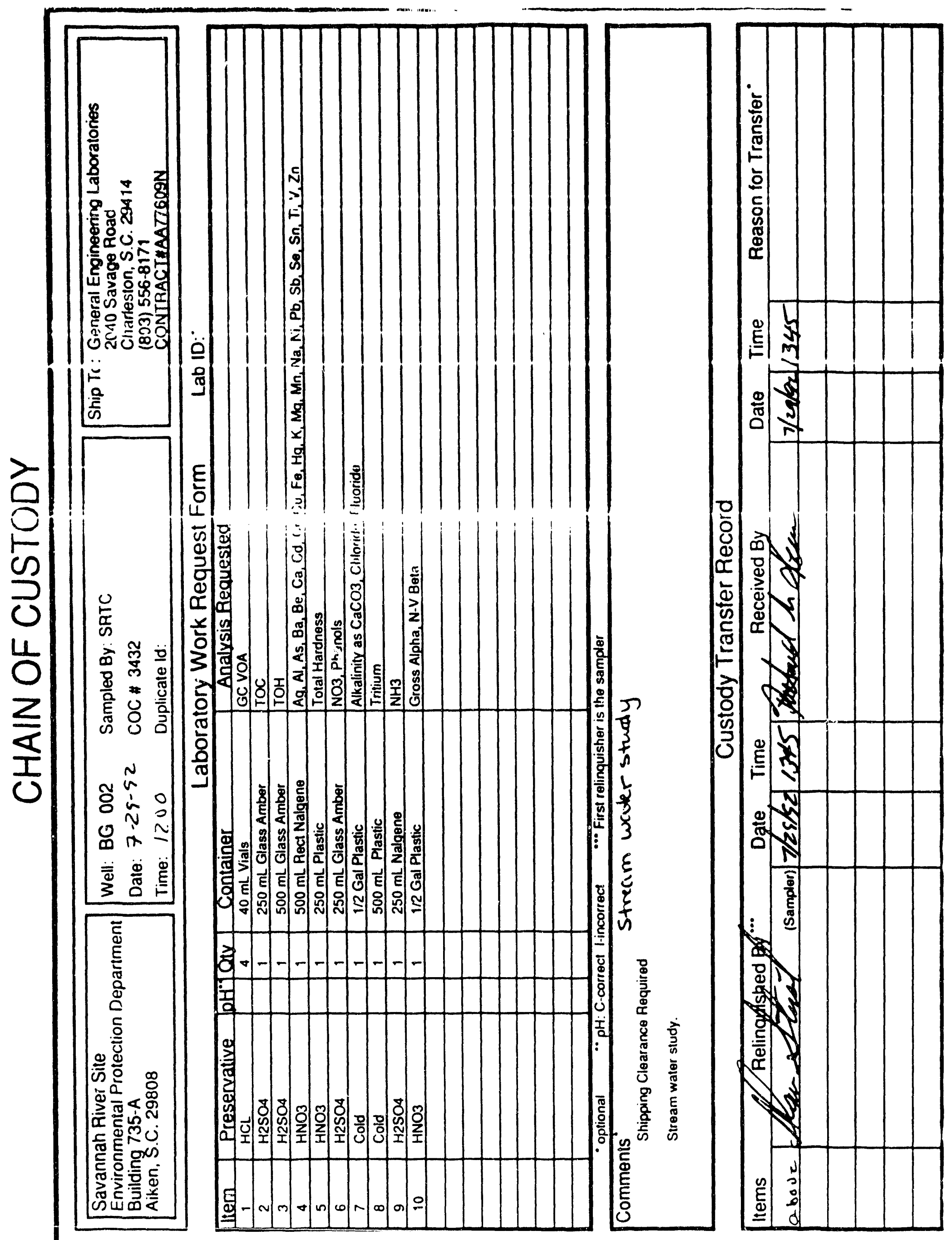




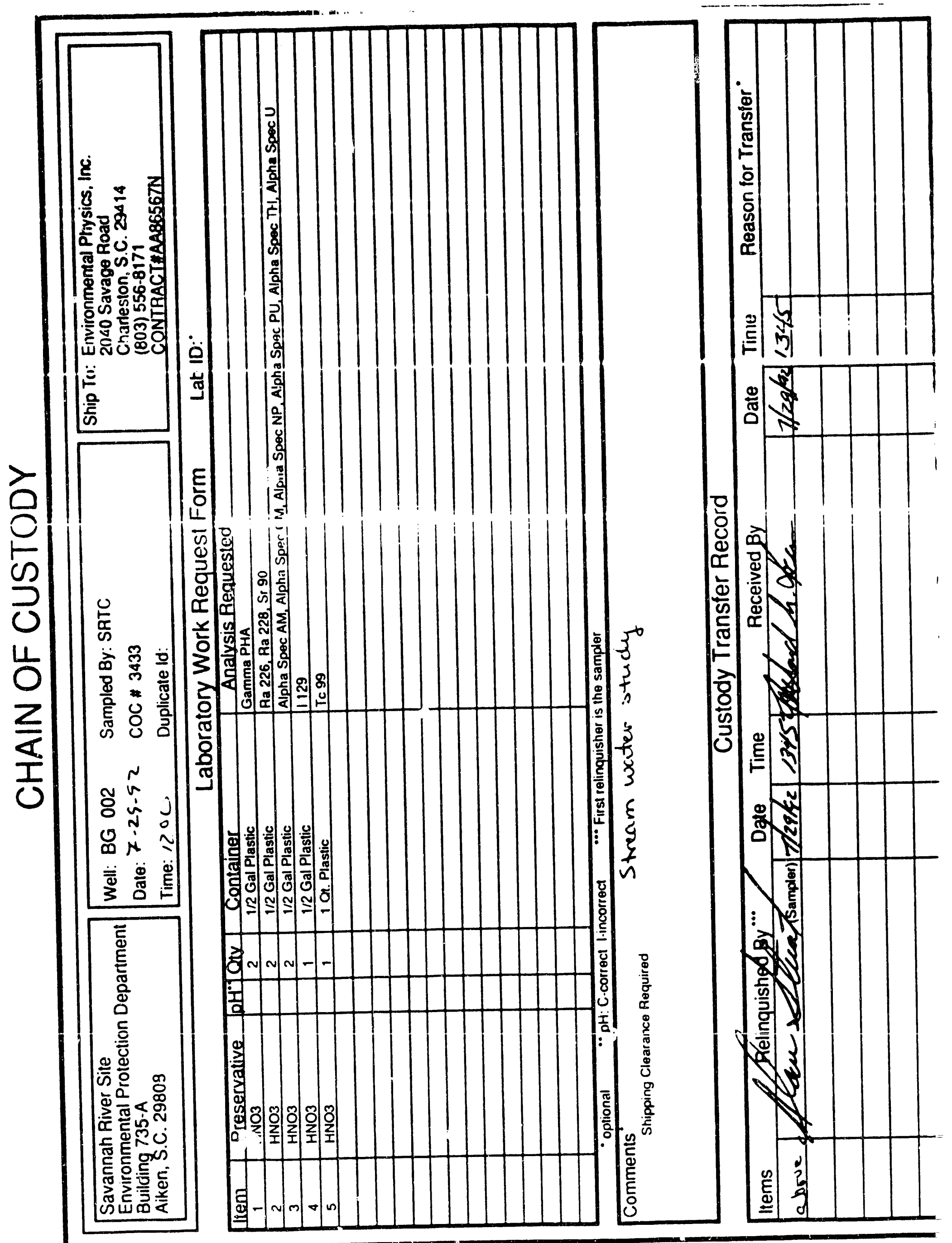




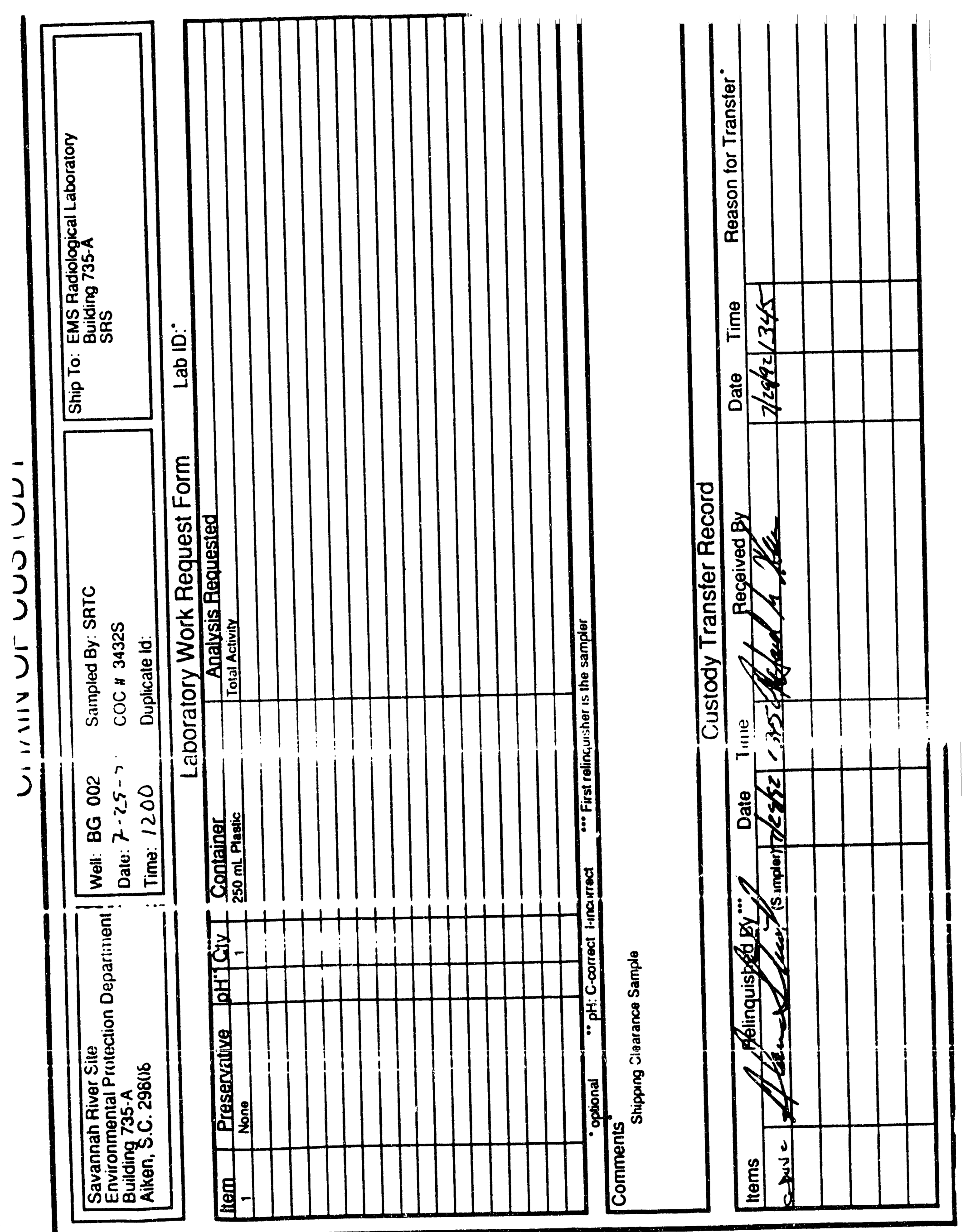




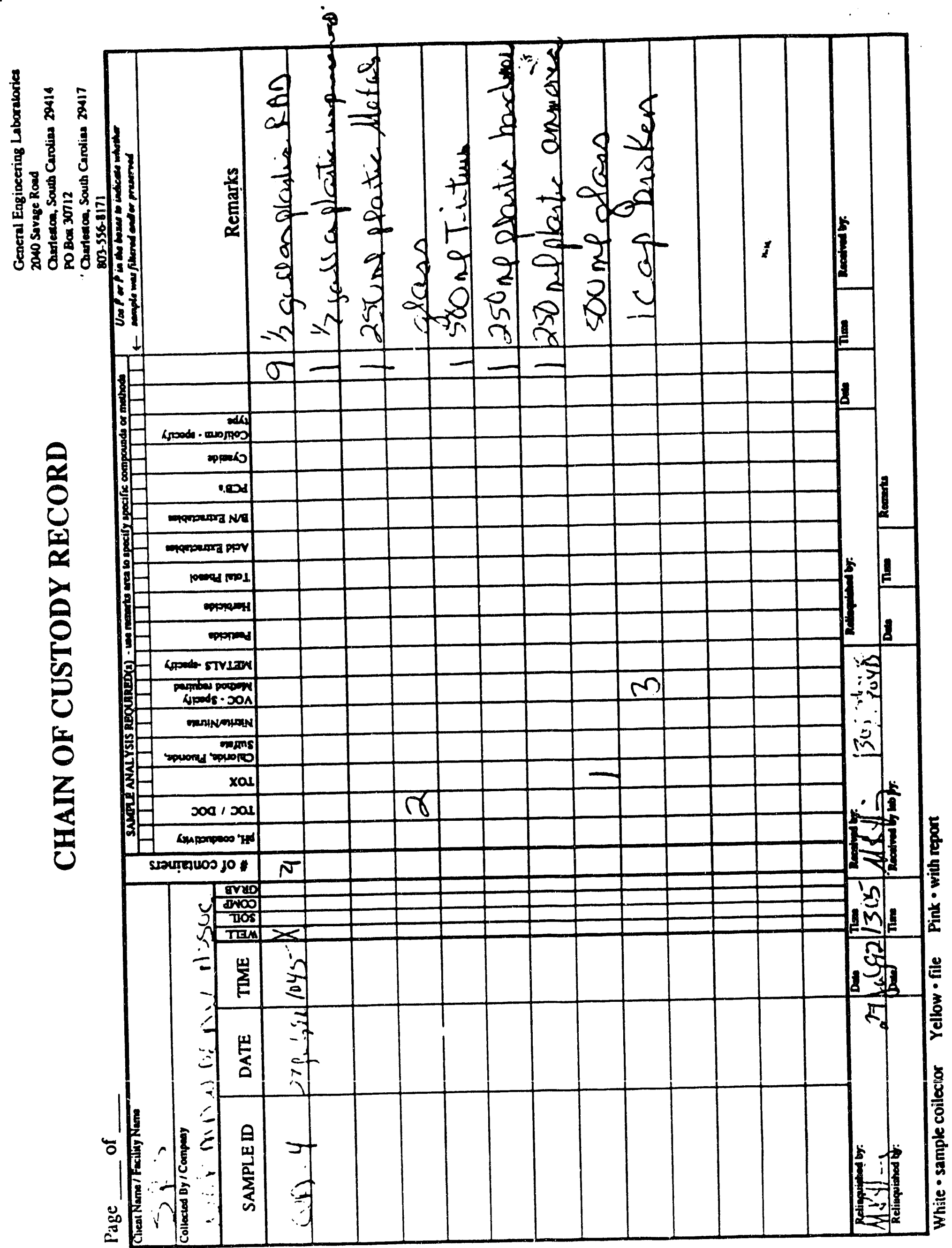




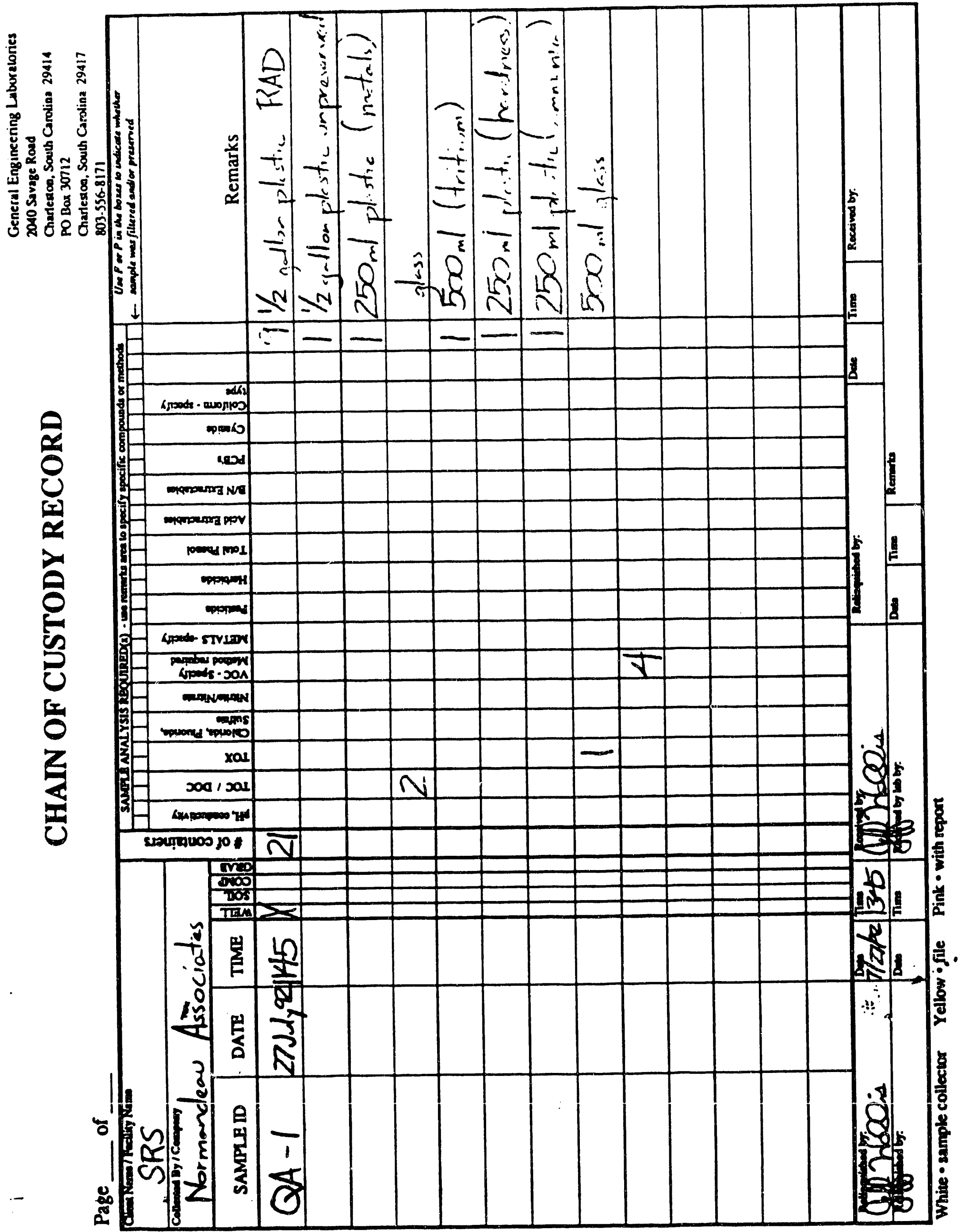




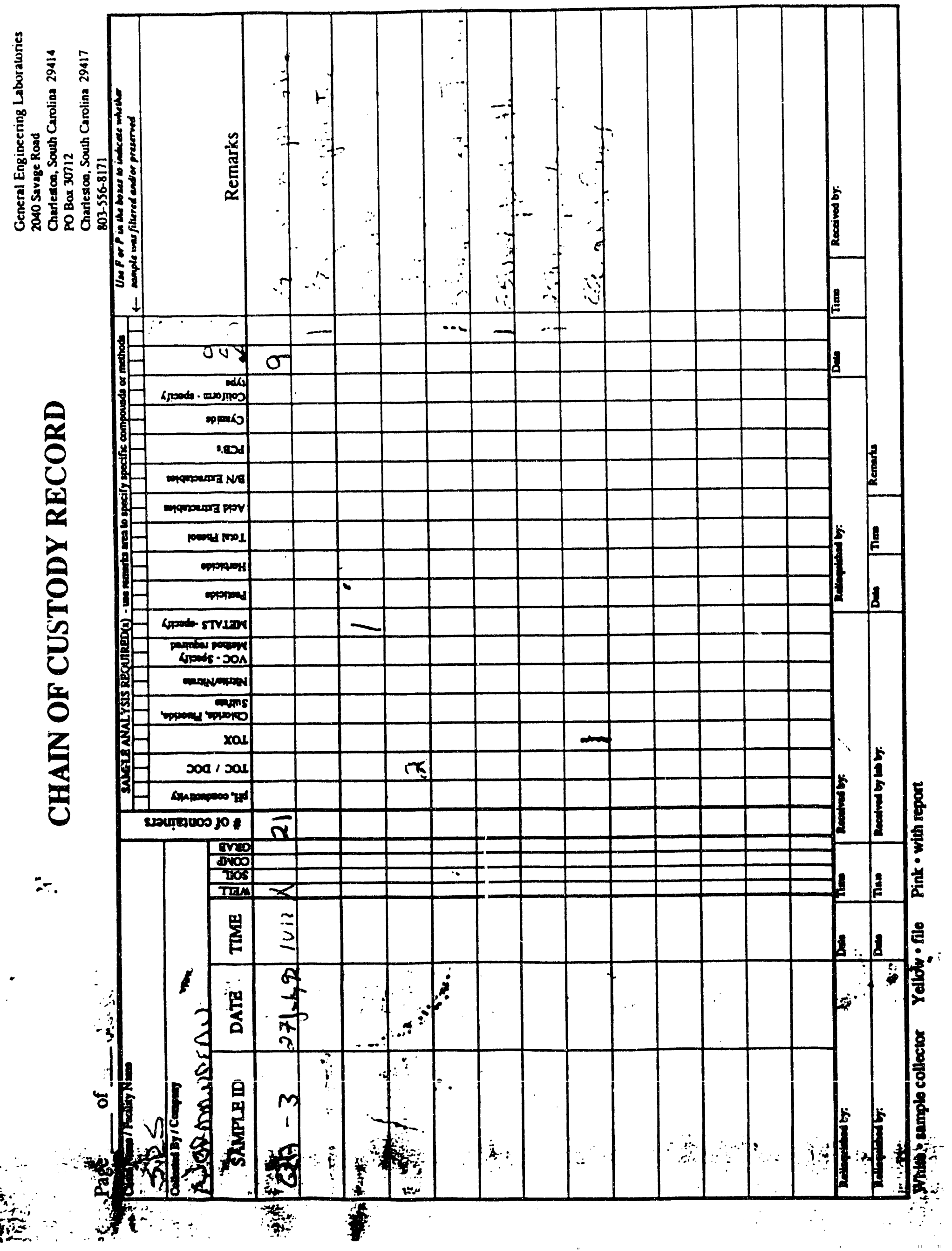




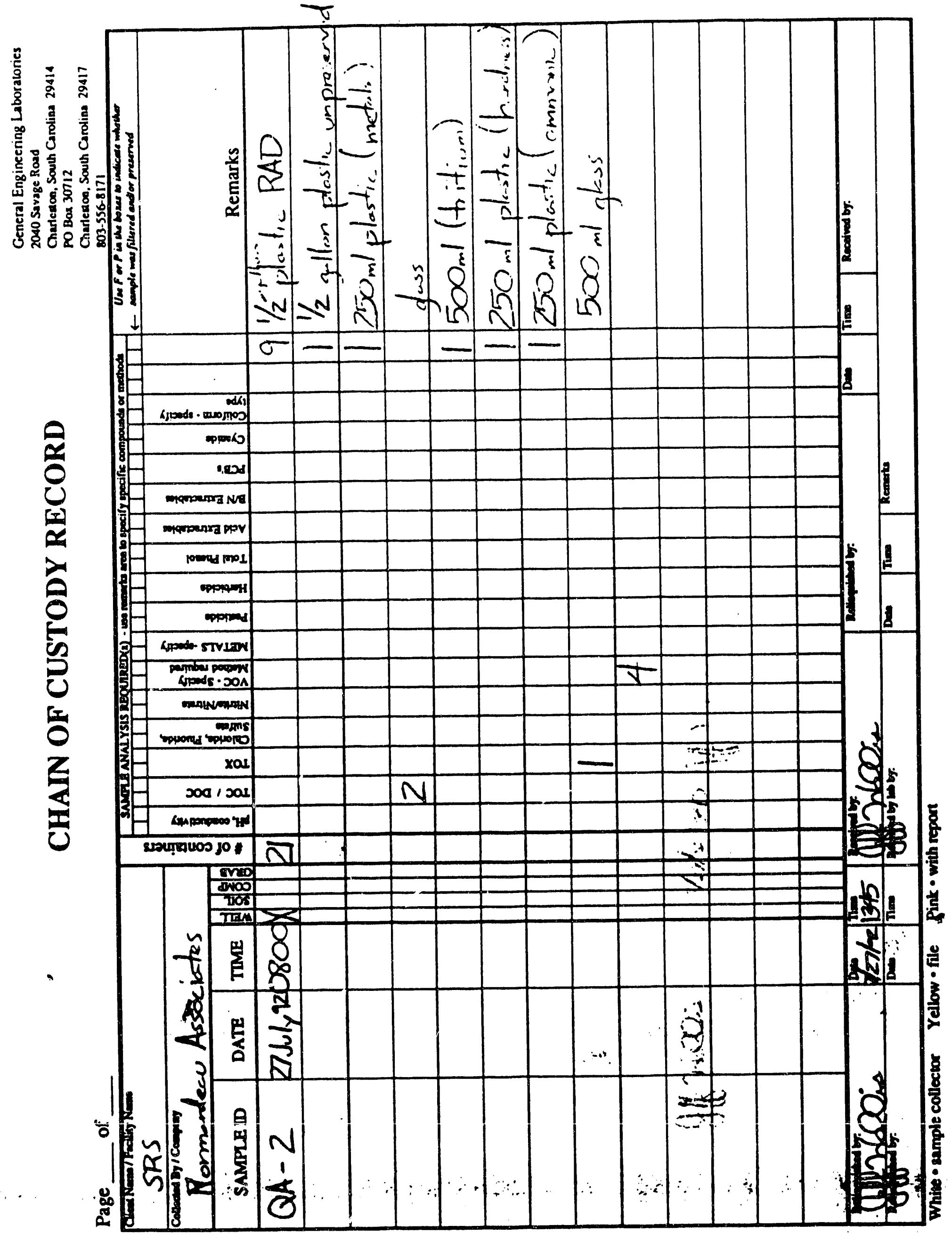


APPENDIX B

Metcalf \& Eddy Surveillance 
July 28,1992

$010005-0001$

To: Gregg Mooney

From: Peter Boucher

Subject: Quality Assurance Surveillance for

Four Mile Creek

Task order No. 26

\section{SURVEILLANCE NARRATIVE}

On Wednesday and Thursday July 22 and 23, 1992, I conducted a quality assurance surveillance of surface and groundwater sampling conducted by Normandeau Associates, Inc. (NAI) at Four Mile Creek which is currently under investigation under Task order No. 26. The purpose of the surveillance was to monitor the sampling operation for consistency with quality assurance procedures developed for the project. Accordingly, I checked that ine equipment, equipment decontamination, instrument calibration, and sampling procedures, were in conformance with procedures outlined in the Quality Assurance Project Plan prepared by M\&E dated June 1992. I also checked that health and safety procedures were followed as outlined in the SHERP dated July 10, 1992.

NAI personnel conducting the work included Kathy Herring, Alan stuart, and Ryan Brady. On Wednesday, I observed the collection of surface water at one station. On Thursday, I observed collection of groundwater at one station where the sampling bucket had been installed on Tuesday.

The surveillance was conducted by reviewing the aforementioned QAPP and generating a series of checklists outlining the critical steps in each phase of the sampling. Actual operations in the field were compared with the checklists. The checklists used and related comments on the operation follow.

\section{CHECKLISTS AND COMMENTS}

Equipment

Field data sheets

Prelabeled sample bottles yes

Pump/Battery/Tygon

Sample Buckets ( 5 gal)

Waterproof pens

Rubber gloves

Water quality meters

Hip boots

Ice

Filter

Mobile phone

First Aid Kit

Fire extinguisher

yes
yes
yes
yes
see below
yes
yes
yes
yes
yes
yes
yes
yes


Comments - The ink used to label the first set of bottles became blurred when the bottles were wet. Permanent markers or ballpoint pens should be used. The MSDS for tritium was not available yet and is to be provided by the STR. An MSDS for Methanol is available in the SHERP.

\section{Instruments}

Calibrate before sampling yes Calibration logbook

yes

Comments - Calibration was conducted before sampling at each station and the results recorded in a logbook.

Sampling procedures

Bottles have preservative PVC stake marks station

Change tubing at each station

Flush pump for 20 secs between samples

Place samples on ice

$\mathrm{pH} / \mathrm{cond} /$ orp

Sample VOAs and metals first

Bottle marked with station, date and time

Rinse probes with DI between measurements

Metals samples filtered

Do not overflow bottles

yes
yes
yes
yes
yes
yes
yes
yes
yes
yes
yes

Comments - The groundwater sample was very turbid and may not accurately reflect the quality of groundwater entering Four Mile creek. The samplers attempted to collect water from the surface, but the turbidity was present throughout the water in the bucket, and may have been caused by the disturbance of installing the bucket, and possibly by a light overnight rain. Material excavated for the bucket was dumped directly adjacent to the hole, possibly contributing to the turbidity. This material should be cast further away from the hole to minimize erosion and turbidity in the event of rain. It should be noted in the lab reports and in the final report that the water quality results were influenced by turbidity resulting from the sampling technique.

A new length of tygon tubing was used for each sample. Part of the surface water filtering was conducted without gloves and several filters were hancled with bare hands. Nitrile gloves should be worn whenever handing samples and during filtering.

Sample bottles were pre-preserved. However, the turbidity of the samples may have added considerable alkalinity. The pH of the samples should be checked and the preservative augmented if necessary. 
The riltering apparatus was rinsed with DI water between stations to minimize cross-contamination.

QA Procedures

Quality assurance samples were collected at both groundwater stations.

Equipment decontamination was conducted off-site and could not be observed directly.

Sample Handing and Packaging

Samples were placed in plastic bags on ice. Samples were to be packaged by HP for radioactivity; thus packaging could not be observed directly.

Health and safety

Hip waders and safety glasses were worn by all samplers. Life jackets were on hand in case of deep water. A mobile phone was available in case of emergency. Each truck was equipped with a first aid kit and fire extinguisher. Boot covers were worn in the exclusion zone of the groundwater sampling station.

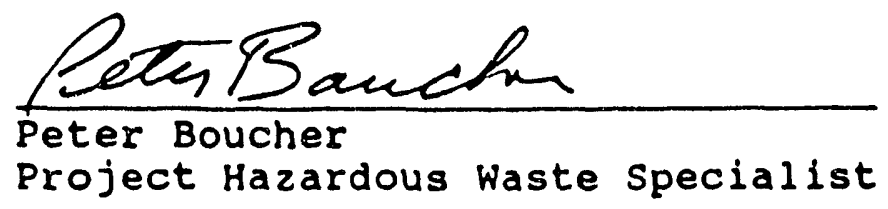



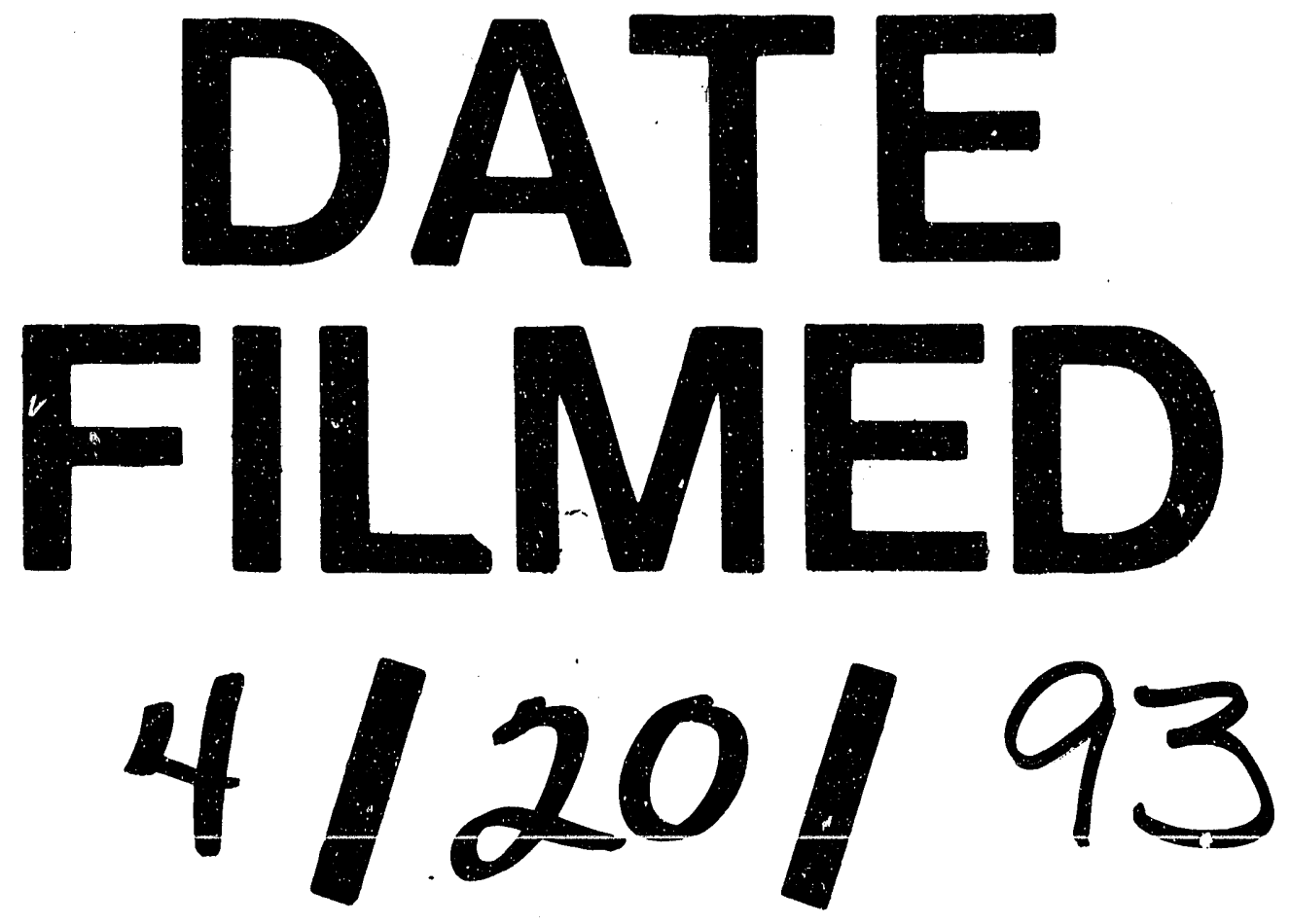
